Supporting Information

\title{
Hydrogenation of $\mathbf{N}$-Heteroarenes Using Rhodium Precatalysts: Reductive Elimination Leads to Formation of Multimetallic Clusters
}

\author{
Sangmin Kim, ${ }^{\dagger}$ Florian Loose, ${ }^{\dagger}$ Máté J. Bezdek, ${ }^{\dagger}$ Xiaoping Wang ${ }^{\ddagger}$ and Paul J. Chirik ${ }^{\star}{ }^{\dagger}$ \\ ${ }^{\dagger}$ Department of Chemistry, Frick Laboratory, Princeton University, Princeton, NJ 08544, USA \\ ${ }^{\ddagger}$ Neutron Scattering Division, Neutron Sciences Directorate, Oak Ridge National Laboratory, \\ Oak Ridge, TN 37831, USA \\ pchirik@princeton.edu
}

\section{Table of Contents}

General Considerations

S2

Preparation of Transition Metal Complexes, 4, 5 and $\mathbf{1 - d _ { 1 }}$

S6

General Procedures

S9

Spectroscopic, Spectrometric, Kinetic and TEM Data 


\section{General Considerations}

All air- and moisture-sensitive manipulations were carried out using vacuum line, Schlenk and cannula techniques or in an MBraun inert atmosphere (nitrogen) dry box unless otherwise noted. All glassware was stored in a pre-heated oven prior to use. The solvents used for airand moisture-sensitive manipulations were dried and deoxygenated using literature procedures. ${ }^{1}$ All N-heteroarene substrates for hydrogenation were purchased from Sigma Aldrich, Alfa Aesar and Acros Organics and dried over $\mathrm{CaH}_{2}$ or molecular sieves followed by the freeze-pump-thaw process for degassing before use. Deuterated organic solvents such as benzene- $d_{6}$ and THF- $d_{8}$ were dried over $\mathrm{CaH}_{2}$ and degassed by freeze-pump-thaw before use. The following compounds were prepared according to literature procedures: $\left[C p^{\star} R h(p p y) H\right](1)$ and $\left[\mathrm{Cp}{ }^{*} \mathrm{Rh}(\mathrm{bq}) \mathrm{H}\right](2) .{ }^{2} \mathrm{NMR}$ spectroscopic data of products were compared with following

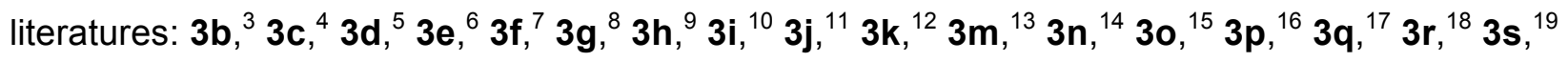
$3 \mathbf{t},{ }^{20} 3 \mathbf{u},{ }^{21} \mathbf{3 v},{ }^{22} 3 \mathbf{w},{ }^{23} 3 \mathbf{x},{ }^{24}$ and $3 \mathbf{y} .{ }^{25}$

${ }^{1} \mathrm{H}$ NMR spectra were recorded on either Bruker ADVANCE 300 or 500 spectrophotometers operating at $300.13 \mathrm{MHz}$, and $500.46 \mathrm{MHz}$, respectively. ${ }^{13} \mathrm{C}$ NMR spectra were recorded on either Bruker ADVANCE 300 or 500 spectrometer operating at $75.48 \mathrm{MHz}$ and $125.85 \mathrm{MHz}$, respectively. All ${ }^{1} \mathrm{H}$ and ${ }^{13} \mathrm{C}$ NMR chemical shifts are reported in ppm relative to $\mathrm{SiMe}_{4}$ using the ${ }^{1} \mathrm{H}$ (chloroform- $d$ : $7.28 \mathrm{ppm}$; benzene- $d_{6}$ : $7.16 \mathrm{ppm}$ ) and ${ }^{13} \mathrm{C}$ (chloroform- $d: 77.16 \mathrm{ppm}$; benzene- $d_{6}: 128.06 \mathrm{ppm}$ ) chemical shifts of the solvent as a standard. ${ }^{1} \mathrm{H}$ NMR data for diamagnetic compounds are reported as follows: chemical shift, multiplicity $(s=$ singlet, $d=$ doublet, $\mathrm{t}=$ triplet, $\mathrm{q}=$ quartet, $\mathrm{p}=$ pentet, $\mathrm{br}=$ broad, $\mathrm{m}=$ multiplet, app $=$ apparent, obsc $=$ obscured), coupling constants $(\mathrm{Hz})$, integration, assignment. ${ }^{1} \mathrm{H}$ NMR data for paramagnetic compounds are reported as follows: chemical shift, integration, peak width at half height $(\mathrm{Hz})$.

${ }^{13} \mathrm{C}$ NMR data for diamagnetic compounds are reported as follows: chemical shift, number of protons attached to carbon (e.g. $\mathrm{CH}_{2}$ ), assignment. 
Elemental analyses were performed at Robinson Microlit Laboratories, Inc., in Ledgewood, NJ. Solid-state magnetic moments were determined using a Johnson Matthey Magnetic Susceptibility Balance that was calibrated with $\mathrm{HgCo}(\mathrm{SCN})_{4}$. High-resolution mass spectra were obtained at Princeton University mass spectrometry facilities using an Agilent 6210 TOF LC/MS. Infrared spectroscopy was conducted on a Thermo-Nicolet iS10 FT-IR spectrometer calibrated with a polystyrene standard.

Single crystals suitable for X-ray diffraction were coated with polyisobutylene oil in a drybox, transferred to a nylon loop and then quickly transferred to the goniometer head of a Bruker SMART APEX DUO diffractometer equipped with a molybdenum X-ray tube $(\lambda=0.71073 \AA)$ and a Cu X-ray tube $(\lambda=1.54178 \AA)$. Preliminary data revealed the crystal system. The data collection strategy was optimized for completeness and redundancy using the Bruker COSMO software suite. The space group was identified, and the data were processed using the Bruker SAINT+ program and corrected for absorption using SADABS. The structures were solved using direct methods (SHELXS) completed by subsequent Fourier synthesis and refined by fullmatrix least-squares procedures.

Parr 4848 reactor controller was used for monitoring pressures and temperatures for kinetic experiments. The volume of the head space of the Parr reactor is roughly $80 \mathrm{~mL}$. The recorded pressured was then transformed into the concentration of pyridine for data analysis. Fitting of plots was conducted using the Matlab software.

Analysis of a distribution of deuterium incorporations was conducted using IsoPat ${ }^{2}$-Mod21 Excel-Worksheet for deconvolution of MS-patters originally made by Gruber and Kroutil and further devised by Lockley. ${ }^{26}$

Transmission Electron Microscopy (TEM) was conducted using Talos F200X Scanning/Transmission Electron Miscroscope (S/TEM) at Imaging and Analysis Center (IAC) at Princeton University. 
Data for $\left(\eta^{5}-C_{5} M\right)_{4}{ }_{4} h_{5} H_{7} \cdot \mathbf{0 . 5 p e n t a n e}$ were collected on the TOPAZ single-crystal time-offlight (TOF) Laue diffractometer at the Spallation Neutron Source, Oak Ridge National Laboratory. ${ }^{27}$ The diffractometer is equipped with 20 detectors, each with an active area of $15 \mathrm{x}$ $15 \mathrm{~cm}$, arranged on a near-spherical detector array tank. The initial moderator-to-sample flight path is $18 \mathrm{~m}$ and the sample-to-detector distances vary in the range $39-46 \mathrm{~cm}$. The total path length of $18.4 \mathrm{~m}$ and the SNS pulse rate of $60 \mathrm{~Hz}$ provides a wavelength bandwidth of $3.6 \mathrm{~A}^{\circ}$. A plate-shaped hydrogenated crystal of $\left(\eta^{5}-C_{5} M e_{5}\right)_{4} R_{5} H_{7} \cdot 0.5 p e n t a n e$, with dimensions of $0.95 x$ $0.75 \times 0.15 \mathrm{~mm}^{3}$, was mounted on the tip of a MiTeGen loop using perfluorinated Krytox grease, and cooled to $100 \mathrm{~K}$ for data collection. A total of 15 crystal orientations optimized with CrystalPlan ${ }^{28}$ software were used to ensure better than $95 \%$ coverage of a hemisphere of reciprocal space. Each orientation was measured for 35 Coulombs of proton-charge for approximately $7 \mathrm{hrs}$ with the SNS operated at $1.4 \mathrm{MW}$. The integrated raw Bragg intensities were obtained using the 3-D ellipsoidal Q-space integration in accordance with previously reported methods. ${ }^{29}$ Data reduction, including neutron TOF spectrum Lorentz and detector efficiency corrections, was carried out with the ANVRED3 program. ${ }^{30} \mathrm{~A}$ spherical numerical absorption correction was applied with $\mu=0.1632+0.1672 \lambda$. The reduced data were saved in the SHELX HKLF2 format, where the wavelength is recorded separately for each individual reflection. Due to the high atomic hydrogen contents $(60 \%$ by atom) and small sample volume, a relatively small number of reflections were observed, which limited a full structural refinement using neutron data alone. The initial neutron structure was refined starting from the X-ray structure, with fixed positional and atomic displacement parameters (ADPs) for all non-hydrogen atoms using the SHELXL-2018/3 program $^{31}$ interfaced with ShelXle. ${ }^{32}$ Hydrogen atoms on the methyl carbon atoms were placed in calculated positions using HFIX with $\mathrm{C}-\mathrm{H}$ distances fixed at $1.08 \mathrm{~A}$, and their isotropic ADPs were refined. Twinning with 2-fold rotation about $\left(\begin{array}{lll}0 & -1 & 1\end{array}\right)$ reciprocal lattice direction was applied for the neutron data. The neutron structure was refined accordingly as a two-component twin using the twin law suggested by ROTAX program in 
WinGX..$^{33}$ In final structure refinement, negative peaks (Figure S49) correspond to the nuclear positions of the seven hydride atoms in $\left(\eta^{5}-\mathbf{C}_{5} \mathbf{M e}_{5}\right)_{4} \mathbf{R h}_{5} \mathrm{H}_{7} \cdot \mathbf{0 . 5}$ pentane were located successfully from the difference Fourier map, and the hydrides were refined isotopically to convergence. Crystal data for $\left(\mathbf{n}^{5}-\mathbf{C}_{5} \mathbf{M e}_{5}\right)_{4} \mathbf{R h}_{5} \mathrm{H}_{7} \cdot \mathbf{0 . 5 p e n t a n e}$ are listed in Table S1. Selected bond lengths $[\AA]$ and angles $\left[{ }^{\circ}\right]$ are listed in Table S2. 


\section{Preparation of Transition Metal Complexes, 4, 5 and 1- $d_{1}$.}

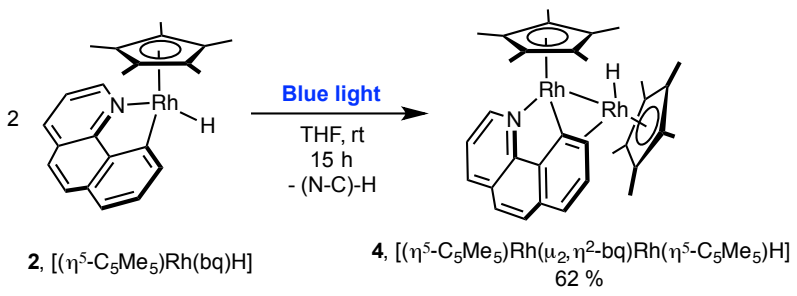

Preparation of $\left[\left(\eta^{5}-C_{5} M_{5}\right) R h\left(\mu_{2}, \eta^{2}-b q\right) R h\left(\eta^{5}-C_{5} M e_{5}\right) H\right], 4.200 m g$ of the compound 2 (0.480 mmol) was added $20 \mathrm{~mL}$ thick-walled glassware in $7 \mathrm{~mL}$ THF with a magnetic stir bar in a $\mathrm{N}_{2}$ filled glovebox. The reaction mixture was stirred at room temperature for $15 \mathrm{~h}$ under blue light with three blue Kessil lamps. After the reaction, all the volatiles were removed under vacuum. The residue was triturated with pentane $(20 \mathrm{~mL} \times 3)$. The remaining solid residue was collected on the M-size frit and washed with pentane $(10 \mathrm{~mL} \times 3)$, which afforded $98 \mathrm{mg}$ of $4(0.150$ mmol) as a brown-purple solid in $62 \%$ yield. The saturated diethylether solution of 4 at $-35^{\circ} \mathrm{C}$ for overnight yielded a red-brown crystal suitable for X-ray diffraction crystallography. Anal Calcd for: C, 60.47; H, 6.00; N, 2.14. Found (first sample): C, 60.29; H, 5.68; N, 1.96. Found (second sample): C, 60.26; H, 5.62; N, 1.62. ${ }^{1} \mathrm{H}$ NMR $\left(300.13 \mathrm{MHz}\right.$, benzene-d $\left.\mathrm{d}_{6}, 23{ }^{\circ} \mathrm{C}\right): \delta 8.91$ $\left(\mathrm{d},{ }^{3} J_{H H}=5.22 \mathrm{~Hz}, 1 \mathrm{H}, \mathrm{bq}\right), 7.57\left(\mathrm{~d},{ }^{3} J_{H H}=7.92 \mathrm{~Hz}, 1 \mathrm{H}, \mathrm{bq}\right), 7.53\left(\mathrm{~d},{ }^{3} J_{H H}=9.58 \mathrm{~Hz}, 1 \mathrm{H}, \mathrm{bq}\right)$, $7.41(\mathrm{~m}, 2 \mathrm{H}, \mathrm{bq}), 7.13\left(\mathrm{~d},{ }^{3} J_{H H}=8.58 \mathrm{~Hz}, 1 \mathrm{H}, \mathrm{bq}\right), 6.83\left(\mathrm{dd},{ }^{3} J_{H H}=8.28,5.23 \mathrm{~Hz}, 1 \mathrm{H}, \mathrm{bq}\right), 5.75$ $\left(\mathrm{dd},{ }^{3} J_{H H}=5.94,1.31 \mathrm{~Hz}, 1 \mathrm{H}, \mathrm{bq}\right), 1.81(\mathrm{~s}, 15 \mathrm{H}, \mathrm{Cp} *), 1.20\left(\mathrm{~s}, 15 \mathrm{H}, \mathrm{Cp} \mathrm{p}^{*}\right),-15.25\left(\mathrm{dd},{ }^{1} J_{R h H}=\right.$ $\left.26.16,{ }^{2} J_{R h H}=2.69 \mathrm{~Hz}, 1 \mathrm{H}, \mathrm{Rh}-H\right) .{ }^{13} \mathrm{C}\left\{{ }^{1} \mathrm{H}\right\}$ NMR $\left(100 \mathrm{MHz}\right.$, benzene-d $\left.6,23^{\circ} \mathrm{C}\right): \delta 154.6\left(\mathrm{C}, J_{R h C}\right.$ $=40.79,14.38 \mathrm{~Hz}, \mathrm{bq}), 151.6(\mathrm{C}, \mathrm{bq}), 149.1(\mathrm{C}=\mathrm{CH}, \mathrm{bq}), 147.9(\mathrm{C}, \mathrm{bq}), 138.6(\mathrm{C}=\mathrm{CH}, \mathrm{bq})$, $129.9(\mathrm{C}=\mathrm{CH}, \mathrm{bq}), 128.64(\mathrm{C}=\mathrm{CH}, \mathrm{bq}), 128.4(\mathrm{C}, \mathrm{bq}), 126.9(\mathrm{C}, \mathrm{bq}), 121.6(\mathrm{C}=\mathrm{CH}, \mathrm{bq}), 120.4(\mathrm{C}$, $\mathrm{C}=\mathrm{CH}$ q), $118.7(\mathrm{C}=\mathrm{CH}, \mathrm{bq}), 93.8\left(J_{R h C}=5.12 \mathrm{~Hz}, C_{5} \mathrm{Me}_{5}\right), 92.5\left(J_{R h C}=5.68 \mathrm{~Hz}, C_{5} \mathrm{Me}_{5}\right), 70.1$ $\left(\mathrm{C}=\mathrm{CH}, J_{R h C}=6.55 \mathrm{~Hz}, \mathrm{bq}\right), 10.8\left(\mathrm{CH}_{3}, \mathrm{C}_{5} M e_{5}\right), 10.3\left(\mathrm{CH}_{3}, \mathrm{C}_{5} \mathrm{Me}_{5}\right)$. 
5

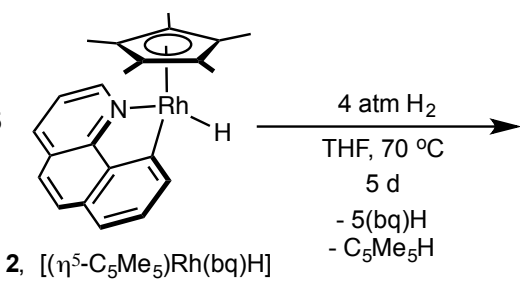

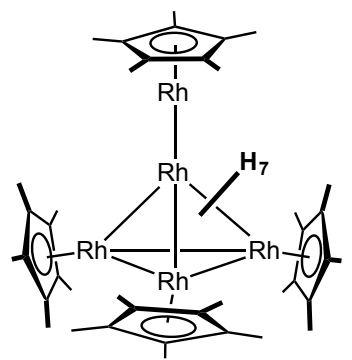

5, $\left[\left(\eta^{5}-\mathrm{C}_{5} \mathrm{Me}_{5}\right)_{4} \mathrm{Rh}_{5} \mathrm{H}_{7}\right]$

Preparation of $\left(\eta^{5}-C_{5} M_{5}\right)_{4} R_{h_{5}} H_{7}, 5.250 \mathrm{mg}$ of the compound $2(0.721 \mathrm{mmol})$ was added 180 $\mathrm{mL}$ thick-walled glassware in $40 \mathrm{~mL}$ THF with a magnetic stir bar in a $\mathrm{N}_{2}$-filled glovebox. $\mathrm{N}_{2}$ atmosphere was displaced with 4 atm $\mathrm{H}_{2}$ when the reaction mixture was frozen by liquid nitrogen. After the solution was slowly thawed by flowing water, the reaction mixture was heated up to $70^{\circ} \mathrm{C}$ and stirred for 5 days. After 5 days, the reaction mixture was cooled down to room temperature and the remaining $\mathrm{H}_{2}$ was released slowly under vacuum while the crude mixture was frozen by liquid nitrogen. Thawed glassware was transferred into the $\mathrm{N}_{2}$-filled glovebox and the volatiles were removed under vacuum. The crude solids were triturated with pentane $(5 \mathrm{~mL}$ X 3). $5 \mathrm{~mL}$ pentane was added to the mixture and the pentane solution was filtered through the glass frit. The first crop of $25 \mathrm{mg}$ of $\mathbf{5}$ was collected on the frit. The filtrate was also collected and the volatile was removed under vacuum. Additional $2 \mathrm{~mL}$ pentane was added and the pentane solution was placed in the freezer at $-35^{\circ} \mathrm{C}$ for recrystallization for overnight to yield the second crop of $35 \mathrm{mg}$ of $\mathbf{5}$ as a dark brown crystal. The total yield from the first and the second crops were $60 \mathrm{mg}(0.0565 \mathrm{mmol}, 39 \%) .{ }^{1} \mathrm{H}$ NMR analysis of the crude mixture shows the NMR yield in $45 \%$. Anal Calcd for : C, 45.22; H, 6.36; N, 0.00. Found: C, 45.60; H, 6.26; N, <0.10. ${ }^{1} \mathrm{H}$ $\operatorname{NMR}\left(300.13 \mathrm{MHz}\right.$, benzene- $\left.\mathrm{d}_{6}, 23^{\circ} \mathrm{C}\right): \delta 2.10\left(\mathrm{~s}, 45 \mathrm{H}, 3 \mathrm{Cp}^{*}\right), 1.93\left(\mathrm{~s}, 15 \mathrm{H}, \mathrm{Cp}{ }^{*}\right),-12.75(\mathrm{dd}$, $\left.{ }^{1} J_{R h H}=34.50,26.58 \mathrm{~Hz}, 3 \mathrm{H}, \mathrm{Rh}-H\right),-13.92(\mathrm{~m}, 3 \mathrm{H}, \mathrm{Rh}-H),-22.54(\mathrm{br} \mathrm{m}, 1 \mathrm{H}, \mathrm{Rh}-H) .{ }^{1} \mathrm{H}$ NMR

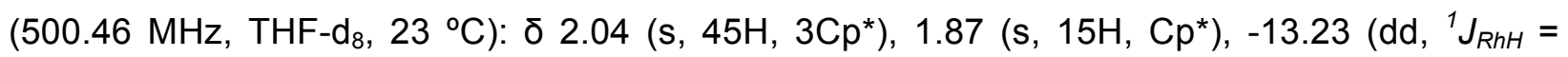
33.49, $27.42 \mathrm{~Hz}, 3 \mathrm{H}, \mathrm{Rh}-H, \mathrm{~T}_{1}(\min )=1270 \mathrm{~ms}$ at $\left.-35^{\circ} \mathrm{C}, 500 \mathrm{MHz}\right),-14.14\left(\mathrm{~m}, 3 \mathrm{H}, \mathrm{Rh}-H_{,} \mathrm{T}_{1}\right.$ $(\min )=606 \mathrm{~ms}$ at $\left.-35^{\circ} \mathrm{C}, 500 \mathrm{MHz}\right),-22.73\left(\mathrm{q},{ }^{1} J_{R h H}=31.51 \mathrm{~Hz}, 1 \mathrm{H}, \mathrm{Rh}-\mathrm{H}_{,} \mathrm{T}_{1}(\min )=722 \mathrm{~ms}\right.$ at 
$\left.-10{ }^{\circ} \mathrm{C}, 500 \mathrm{MHz}\right) .{ }^{13} \mathrm{C}\left\{{ }^{1} \mathrm{H}\right\}$ NMR $\left(75.48 \mathrm{MHz}\right.$, benzene-d $\left.\mathrm{d}_{6}, 23{ }^{\circ} \mathrm{C}\right): \delta 95.1\left(\mathrm{C}, 3 \mathrm{C}_{5} \mathrm{Me}_{5}\right), 92.8(\mathrm{C}$, $\left.\mathrm{C}_{5} \mathrm{Me}_{5}\right), 12.4\left(\mathrm{CH}_{3}, 3 \mathrm{C}_{5} \mathrm{Me}_{5}\right), 12.3\left(\mathrm{CH}_{3}, \mathrm{C}_{5} \mathrm{Me}_{5}\right)$.

Preparation of $\left[\left(n^{5}-C_{5} M_{5}\right) R h(p p y) D\right], 1-d_{1} .100 m g$ of the compound 1 was added to a $20 \mathrm{~mL}$ vial in $10 \mathrm{~mL}$ toluene with a magnetic stir bar in a $\mathrm{N}_{2}$-filled glovebox. The reaction mixture was stirred at room temperature for $2 \mathrm{~h}$. After the reaction, all the volatiles were removed under vacuum. The residue was triturated with pentane $(3 \mathrm{~mL} X 2)$. The remaining solid residue was collected on the M-size frit and washed with pentane ( $3 \mathrm{~mL} \times 2)$, which afforded $112 \mathrm{mg}$ of a red-brown solid. The red-brown solid was dissolved in $5 \mathrm{~mL}$ THF in a $20 \mathrm{~mL}$ thick-walled glassware. $\mathrm{N}_{2}$ atmosphere was displaced with 4 atm of $D_{2}$ and the reaction mixture was stirred at room temperature for $30 \mathrm{~min}$. Then, the THF solution was reduced by $1 \mathrm{~mL}$ and $3 \mathrm{~mL}$ pentane was added for recrystallization at rt. The resulting solid was collected on the frit and washed with pentane ( $1 \mathrm{~mL} \times 3)$, which afforded $83 \mathrm{mg}$ of $1-\boldsymbol{d}_{1}$ as a yellow solid. 


\section{General Procedures}

General Catalytic Procedures for $\mathbf{N}$-Heteroarene Hydrogenation: Method A. In a typical experiment, a $180 \mathrm{~mL}$ thick-walled glassware was charged with $20 \mathrm{mg}$ of 1 , a magnetic stir bar and $1 \mathrm{~mL}$ THF in the $\mathrm{N}_{2}$-filled glovebox. The reaction mixture was frozen using liquid nitrogen and $\mathrm{N}_{2}$ was displaced with 4 atm $\mathrm{H}_{2}$. The reaction mixture was stirred at $80{ }^{\circ} \mathrm{C}$ for $24 \mathrm{~h}$, then $\mathrm{H}_{2}$ and the volatiles were removed under vacuum. $5.0 \mathrm{mmol}$ of substrate was added the glassware in the $\mathrm{N}_{2}$-filled glovebox. The mixture was frozen using liquid nitrogen and $4 \mathrm{~atm} \mathrm{H}_{2}$ was added. The reaction mixture was thawed and stirred at $80^{\circ} \mathrm{C}$ for $48 \mathrm{~h}$. After $48 \mathrm{~h}$, the $\mathrm{H}_{2}$ pressure was slowly released while the mixture was frozen by liquid nitrogen. The resulting product was then analyzed by ${ }^{1} \mathrm{H}$ NMR spectroscopy using $1.0 \mathrm{mmol}$ ( 0.20 equiv) of mesitylene as an internal standard.

Piperidine, 3a: ${ }^{1} \mathrm{H}$ NMR $\left(300 \mathrm{MHz}\right.$, benzene- $\left.d_{6}, 23{ }^{\circ} \mathrm{C}\right): \delta 2.60\left(\mathrm{t}, 4 \mathrm{H}, 2,6-\mathrm{CH}_{2}\right), 1.38(\mathrm{~m}, 6 \mathrm{H}$, 3,4,5- $\left.\mathrm{CH}_{2}\right), 1.23(\mathrm{br}, 1 \mathrm{H}, \mathrm{NH})$.

Method B. In a typical experiment, a $1.5 \mathrm{~mL} \mathrm{GC}$ vial was charged with $20 \mathrm{mg}$ of 1 and $5.0 \mathrm{mmol}$ of substrate in the $\mathrm{N}_{2}$-filled glovebox. (For a solid substrate, $1.0 \mathrm{mmol}$ of substrate in $1.0 \mathrm{~mL}$ THF was used.) The vial was placed in the Parr reactor and usually four vials were placed at the same time for catalysis. The reactor was charged with 36 atm $\mathrm{H}_{2}$ and heated up to $100{ }^{\circ} \mathrm{C}$. After $48 \mathrm{~h}$, the $\mathrm{H}_{2}$ pressure was slowly released to prevent the loss of products. The resulting product was then analyzed by ${ }^{1} \mathrm{H}$ NMR spectroscopy using $1.0 \mathrm{mmol}$ of mesitylene as an internal standard.

1,4-Diaminobutane, 3I: ${ }^{1} \mathrm{H}$ NMR (300 MHz, benzene- $\left.d_{6}, 23{ }^{\circ} \mathrm{C}\right): \delta$ 2.51-2.42 (m, 4H), 1.29-1.15 (m, 2H), $0.55\left(\mathrm{br}, 4 \mathrm{H}, \mathrm{NH}_{2}\right)$.

Method C. In a typical experiment, a $180 \mathrm{~mL}$ thick-walled glassware was charged with $20 \mathrm{mg}$ of 1, a magnetic stir bar and $1 \mathrm{~mL}$ THF in the $\mathrm{N}_{2}$-filled glovebox. The reaction mixture was frozen using liquid nitrogen and $\mathrm{N}_{2}$ was displaced with 4 atm $\mathrm{H}_{2}$. The reaction mixture was stirred at 80 ${ }^{\circ} \mathrm{C}$ for $24 \mathrm{~h}$, then $\mathrm{H}_{2}$ and the volatiles were removed under vacuum. $1.0 \mathrm{mmol}$ of solid substrate 
and $1.0 \mathrm{~mL}$ THF were added the glassware in the $\mathrm{N}_{2}$-filled glovebox. The mixture was frozen using liquid nitrogen and $4 \mathrm{~atm} \mathrm{H}_{2}$ was added. The reaction mixture was thawed and stirred at $80{ }^{\circ} \mathrm{C}$ for $48 \mathrm{~h}$. After $48 \mathrm{~h}$, the $\mathrm{H}_{2}$ gas and the volatiles were removed under vacuum. The resulting product was then analyzed by ${ }^{1} \mathrm{H}$ NMR spectroscopy using $1.0 \mathrm{mmol}$ of mesitylene as an internal standard.

Deuteration of Pyridine Using $\mathbf{D}_{2}$. A $180 \mathrm{~mL}$ thick-walled glassware was charged with $20 \mathrm{mg}$ of 1 , a magnetic stir bar and $5.0 \mathrm{mmol}$ of pyridine in the $\mathrm{N}_{2}$-filled glovebox. The reaction mixture was frozen using liquid nitrogen and $N_{2}$ was displaced with $4 \operatorname{atm} D_{2}$. The reaction mixture was stirred at $80{ }^{\circ} \mathrm{C}$ for $48 \mathrm{~h}$, then the $\mathrm{D}_{2}$ pressure was slowly released. The resulting product was then analyzed by ${ }^{1} \mathrm{H}$, quantitative ${ }^{13} \mathrm{C}$ NMR spectroscopy and LC/MS.

In Situ Activation of 1 for the Cluster Formation and Pyridine Hydrogenation. 6 mg of 1 was dissolved in $0.750 \mathrm{~mL} \mathrm{THF-d_{8 }}$ to be used as a $0.02 \mathrm{M}$ stock solution. To a J-Young NMR tube, $5.0 \mu \mathrm{L}$ of the stock solution, $5.0 \mu \mathrm{L}$ of pyridine and $0.5 \mathrm{~mL}$ of THF- $\mathrm{d}_{8}$ were added in the $\mathrm{N}_{2^{-}}$ filled glovebox. When the solution was frozen by liquid nitrogen, $\mathrm{N}_{2}$ atmosphere was displaced with 4 atm of $\mathrm{H}_{2}$. After the tube was thawed, it was placed in an oil bath at $60{ }^{\circ} \mathrm{C}$ without stirring. The crude reaction mixture was monitored by ${ }^{1} \mathrm{H}$ NMR spectroscopy after $24 \mathrm{~h}$.

H/D Scrambling Experiment in the Compound 1. A J-Young NMR tube was charged with 2 $\mathrm{mg}$ of 1 and $0.4 \mathrm{~mL}$ of THF- $\mathrm{d}_{8}$ in the $\mathrm{N}_{2}$-filled glovebox. The tube was wrapped with an Al foil to screen light and placed on the bench at room temperature for $40 \mathrm{~h}$ without stirring. The crude reaction mixture was monitored by ${ }^{1} \mathrm{H}$ NMR spectroscopy.

Deuterium Incorporation into 5 under $\mathbf{D}_{2}$ atmosphere. A J-Young NMR tube was charged with $2 \mathrm{mg}$ of 5 and $0.4 \mathrm{~mL}$ of benzene- $\mathrm{d}_{6}$ in the $\mathrm{N}_{2}$-filled glovebox. When the solution was frozen 
by liquid nitrogen, $N_{2}$ atmosphere was displaced with 4 atm of $D_{2}$. After the tube was thawed, it was placed on the bench at room temperature for 30 min without stirring. Then, the crude reaction mixture was monitored by ${ }^{1} \mathrm{H}$ NMR spectroscopy.

Kinetic Experiments. In the $\mathrm{N}_{2}$-filled glovebox, a rhodium complex of $0.25 \mathrm{~mol} \%$ of $\mathrm{Rh}$ atom to substrate and $1.0 \mathrm{~mL}$ pyridine were added in a $2.0 \mathrm{~mL}$ GC vial. The vial was placed in the Parr reactor and the reactor was brought out of the glovebox. The reactor was heated up to $70{ }^{\circ} \mathrm{C}$ and then more than 530 psi of $\mathrm{H}_{2}$ was charged. $\mathrm{H}_{2}$ was then slowly released down to 530 psi which make the temperature roughly $78{ }^{\circ} \mathrm{C}$. Right after the $\mathrm{H}_{2}$ addition, the pressure and temperature were recorded in every 30 minutes. The reaction was completed when the pressured was decreased down to around 308 psi.

Conversion of 4 Under $\mathrm{H}_{2}$ Atmosphere. A $5 \mathrm{mg}$ of 4 in $1.0 \mathrm{~mL}$ of THF- $\mathrm{d}_{8}$ was added a $10 \mathrm{~mL}$ thick-walled glassware with a magnetic stir bar in the $\mathrm{N}_{2}$-filled glovebox. When the solution was frozen by liquid nitrogen, $\mathrm{N}_{2}$ atmosphere was displaced with 4 atm of $\mathrm{H}_{2}$. After the solution was thawed, the reaction mixture was stirred at room temperature for $18 \mathrm{~h}$. The crude reaction mixture and their molecular ratio were monitored by ${ }^{1} \mathrm{H}$ NMR spectroscopy.

Benzo[h]quinoline: ${ }^{1} \mathrm{H}$ NMR (300 MHz, THF- $\left.d_{8}, 23^{\circ} \mathrm{C}\right): \delta$ 9.35-9.27 (m, 1H), $8.95(\mathrm{dd}, 1 \mathrm{H}), 8.24$ (dd, 1H), 7.95-7.88 (m, 1H), $7.84(\mathrm{~d}, 1 \mathrm{H}), 7.73(\mathrm{~d}, 1 \mathrm{H}), 7.72-7.63(\mathrm{~m}, 2 \mathrm{H}), 7.54(\mathrm{dd}, 1 \mathrm{H})$. 
IV. Spectroscopic, Spectrometric, Kinetic and TEM Data

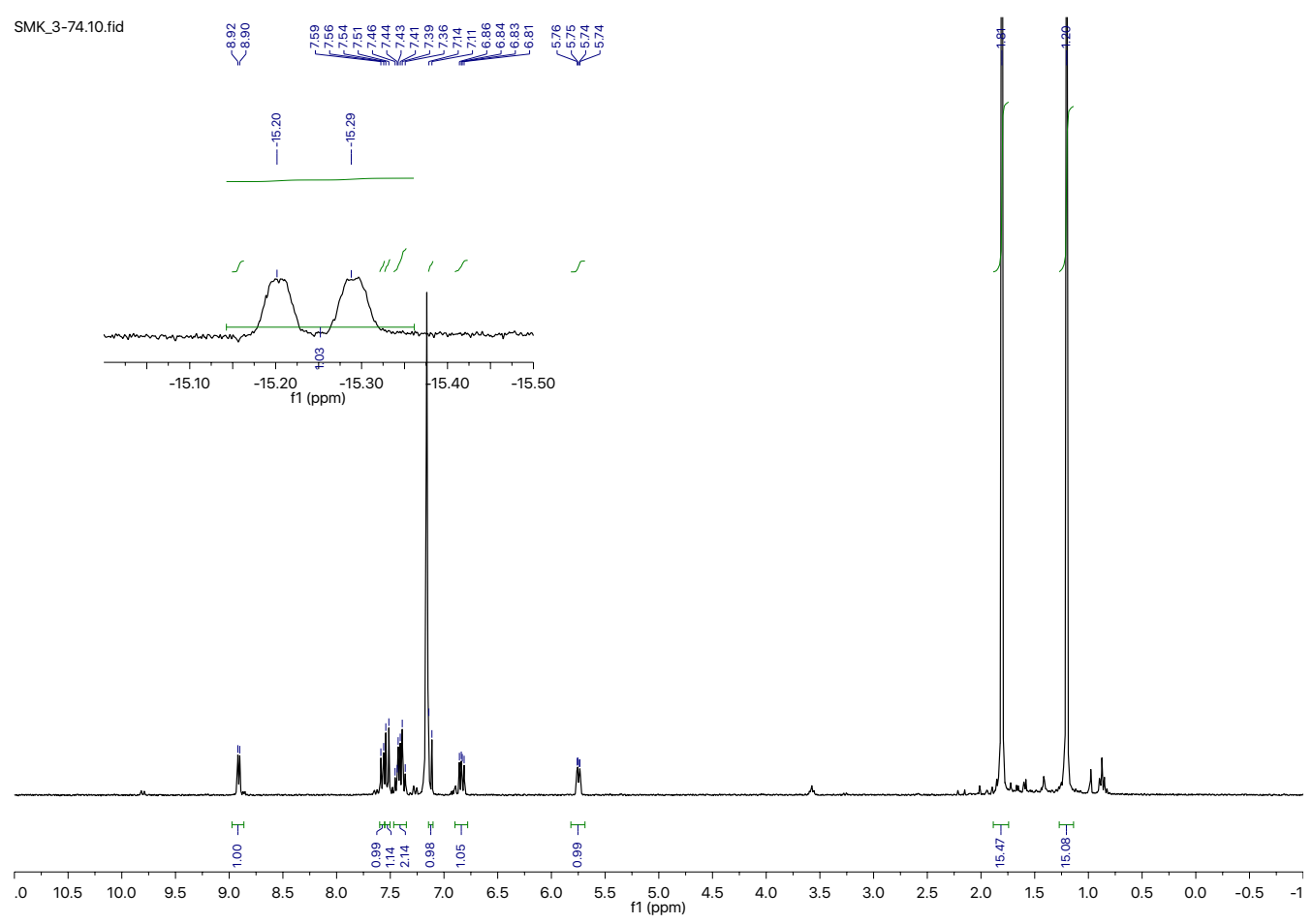

Figure S1. ${ }^{1} \mathrm{H}$ NMR spectrum of 4 in benzene- $d_{6}$. The inset is an expanded view of the diagnostic hydride region. 


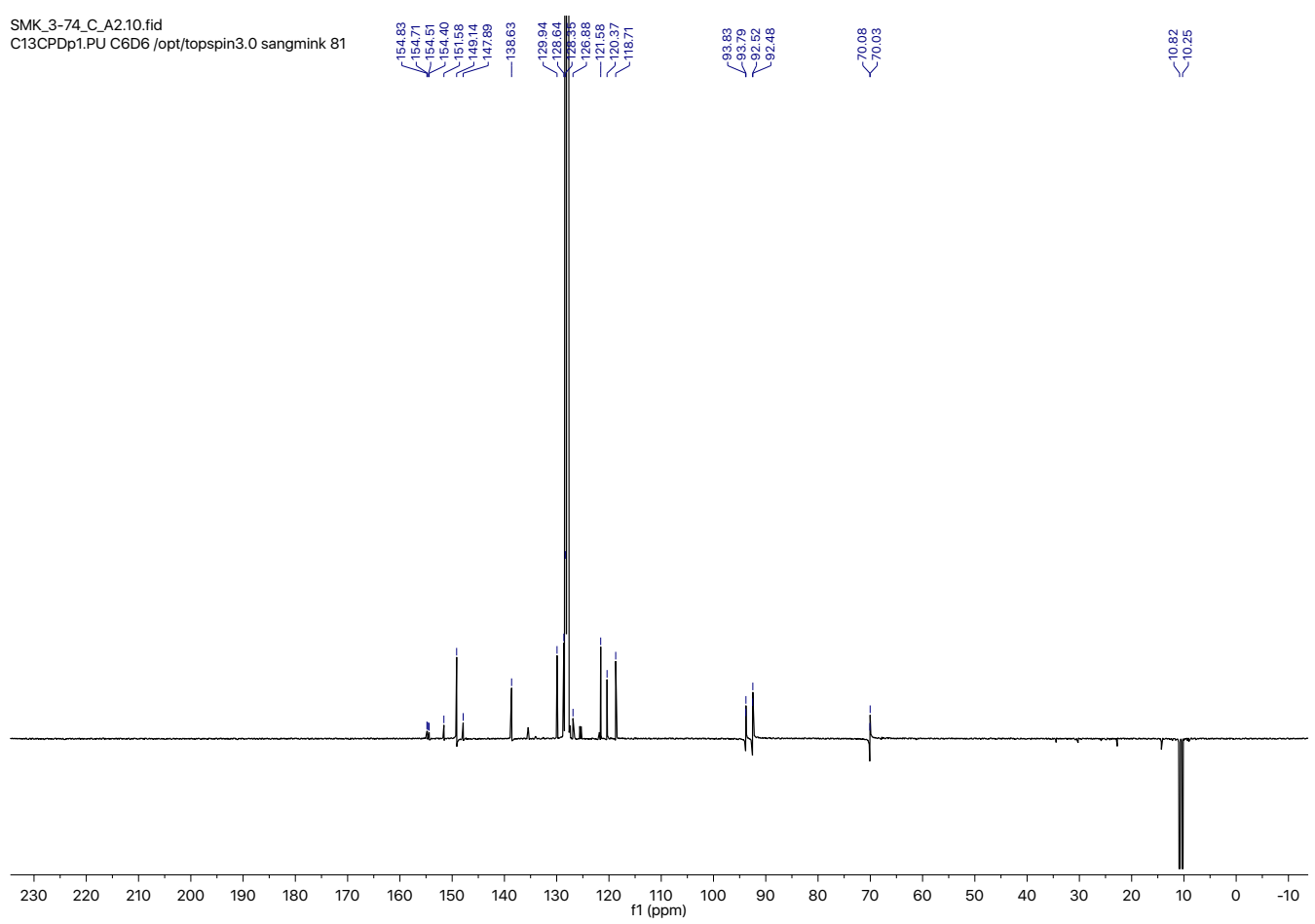

Figure S2. ${ }^{13} \mathrm{C}\left\{{ }^{1} \mathrm{H}\right\}$ NMR spectrum of 4 in benzene- $d_{6}$.

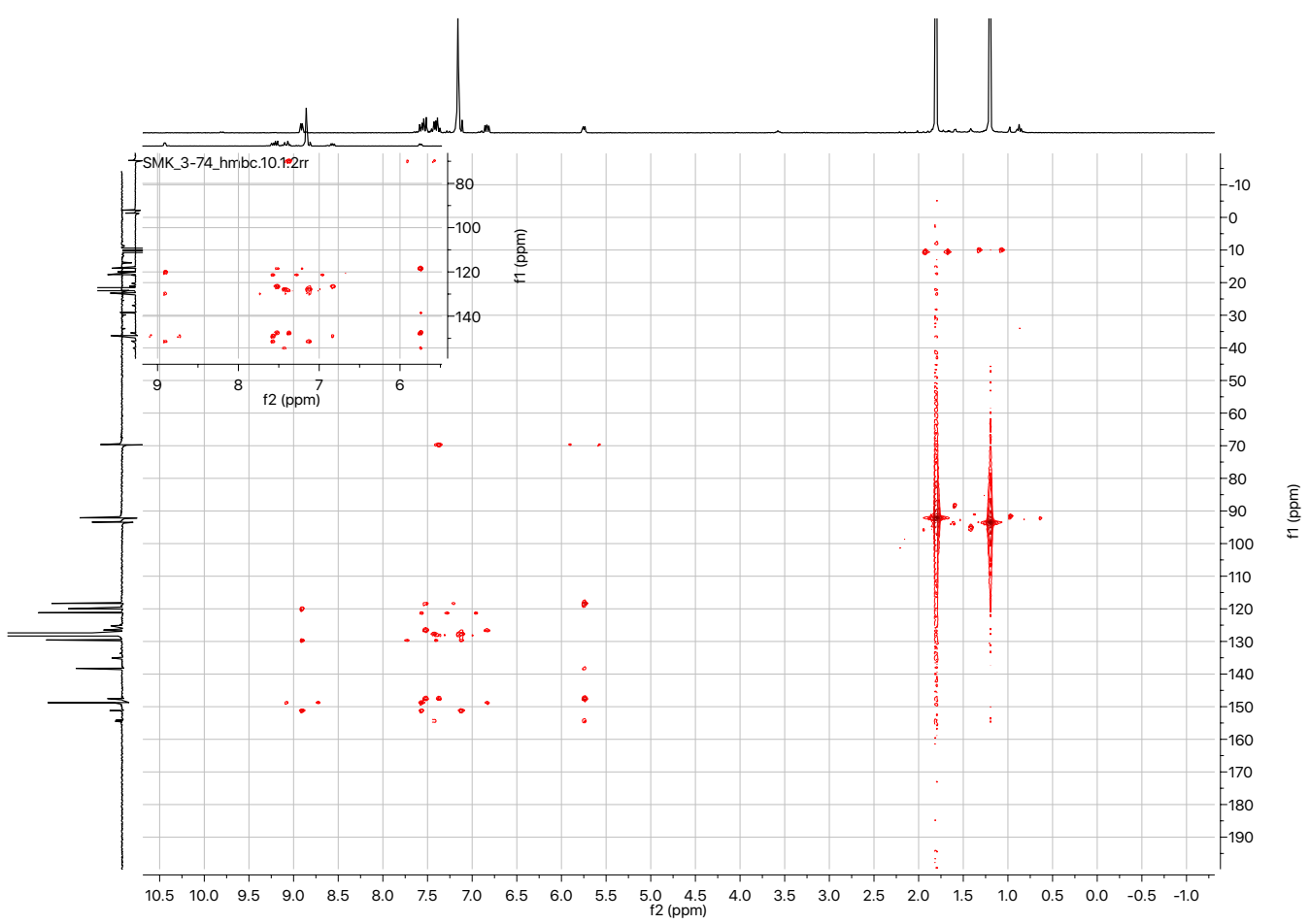

Figure S3. 2D ${ }^{1} \mathrm{H}-{ }^{13} \mathrm{C}$ HMBC NMR spectrum of 4 in benzene- $d_{6}$. The inset is an expanded view of the diagnostic benzo[h]quinolinyl region. 


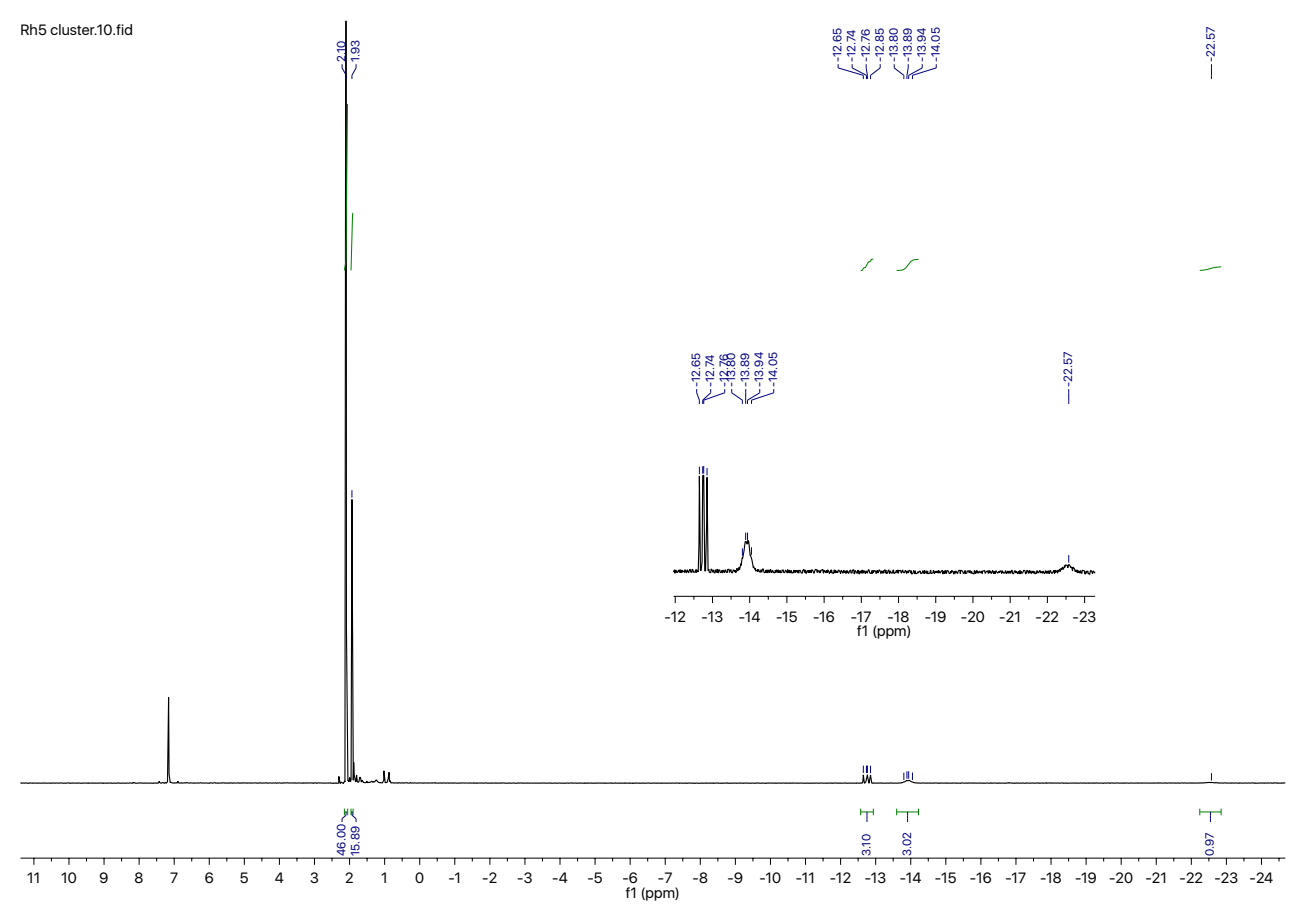

Figure S4. ${ }^{1} \mathrm{H}$ NMR spectrum of 5 in benzene- $d_{6}$. The inset is an expanded view of the diagnostic hydrides region.

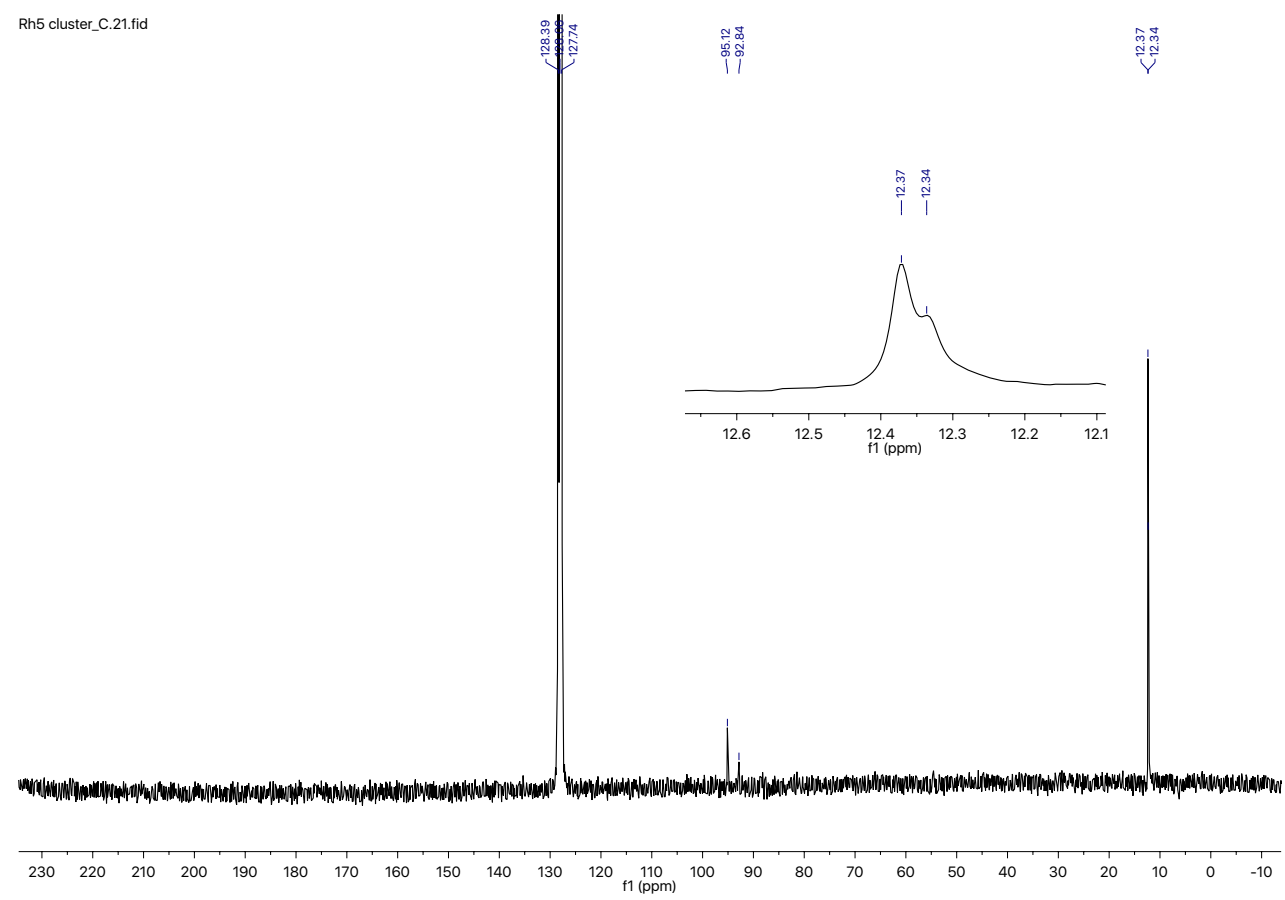

Figure S5. ${ }^{13} \mathrm{C}\left\{{ }^{1} \mathrm{H}\right\}$ NMR spectrum of 5 in benzene- $d_{6}$. The inset is an expanded view of the diagnostic $\mathrm{Cp}^{*}$ region. 

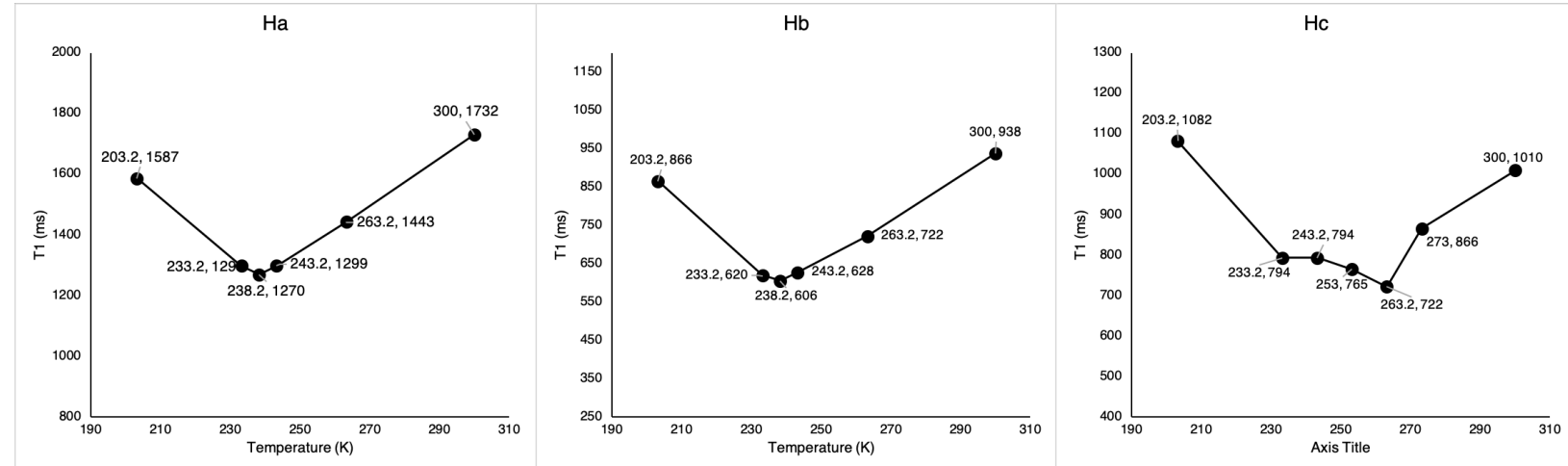

Figure S6. $\mathrm{T}_{1}(\mathrm{~min})$ measurements of three hydrides of 5 in THF- $d_{8}$ at $500 \mathrm{MHz} \cdot \mathrm{H}_{\mathrm{a}}=-13.23$ (dd, ${ }^{1} J_{R h H}=33.49,27.42 \mathrm{~Hz}, 3 \mathrm{H}, \mathrm{Rh}-\mathrm{H}, \mathrm{T}_{1}(\mathrm{~min})=1270 \mathrm{~ms}$ at $\left.-35^{\circ} \mathrm{C}, 500 \mathrm{MHz}\right), \mathrm{H}_{\mathrm{b}}=-14.14(\mathrm{~m}, 3 \mathrm{H}$, $\mathrm{Rh}-H, \mathrm{~T}_{1}(\mathrm{~min})=606 \mathrm{~ms}$ at $\left.-35^{\circ} \mathrm{C}, 500 \mathrm{MHz}\right), \mathrm{H}_{\mathrm{c}}=-22.73\left(\mathrm{q},{ }^{1} J_{R h H}=31.51 \mathrm{~Hz}, 1 \mathrm{H}, \mathrm{Rh}-\mathrm{H}_{1}, \mathrm{~T}_{1}\right.$ $(\min )=722 \mathrm{~ms}$ at $\left.-10^{\circ} \mathrm{C}, 500 \mathrm{MHz}\right)$.

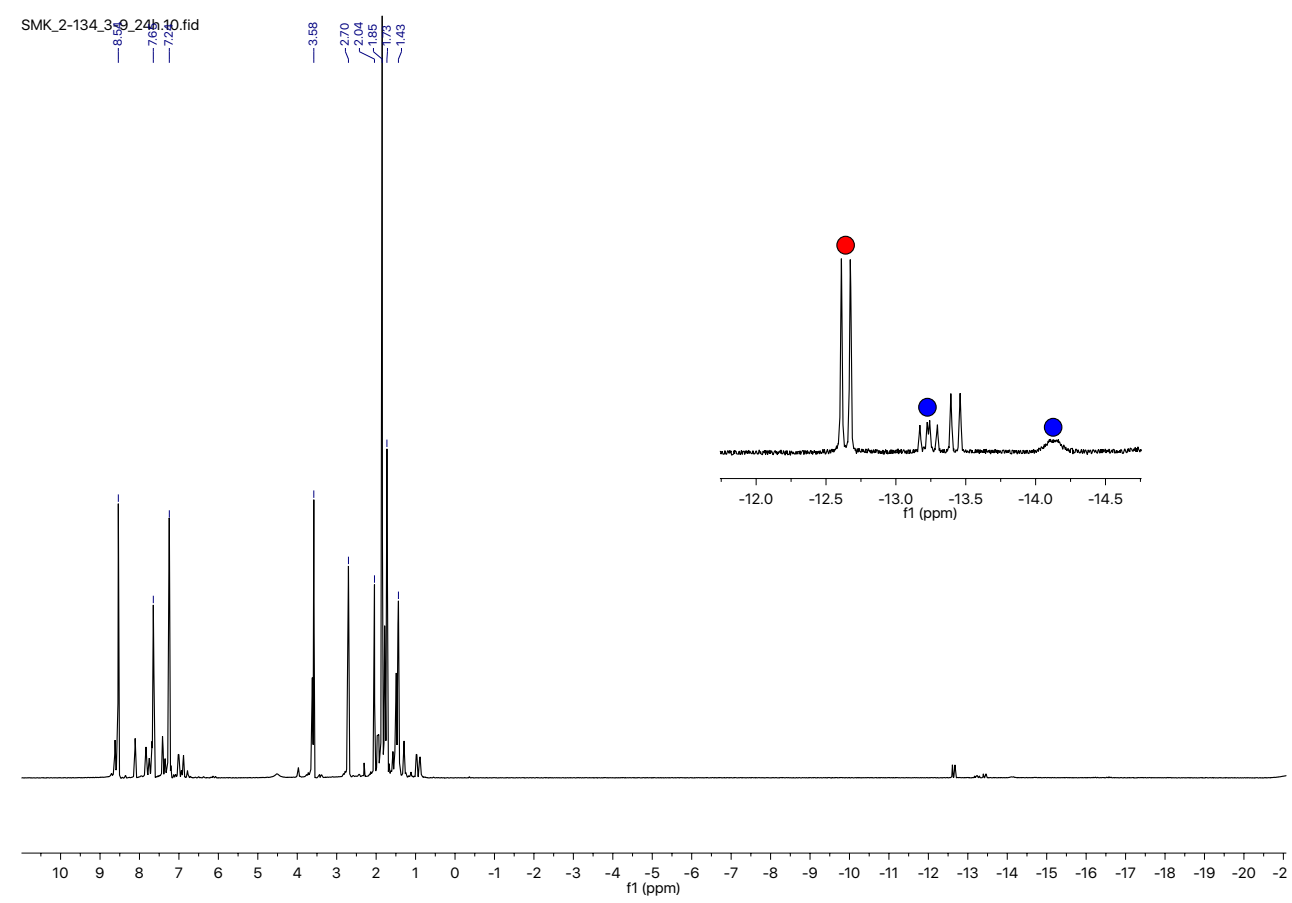

Figure S7. Representative ${ }^{1} \mathrm{H}$ NMR spectrum of the initial investigation on the hydrogenation of pyridine using 1 as a catalyst in THF- $d_{8}$ for $24 \mathrm{~h}$ under $4 \mathrm{~atm} \mathrm{H}_{2}$. The inset is an expanded view of the diagnostic hydrides region. (Red dot: 1 , blue dots: 5 ) 


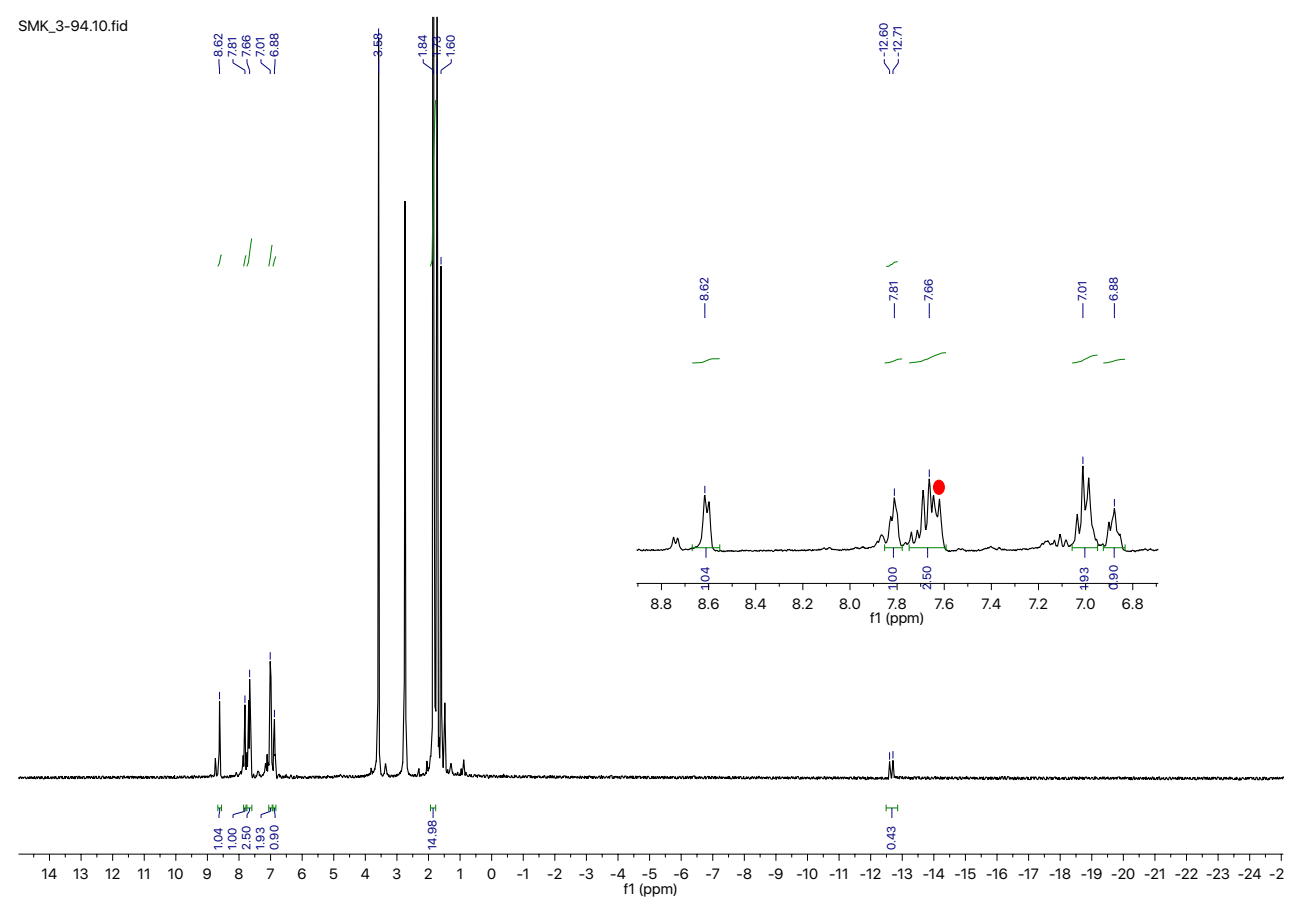

Figure S8. Representative ${ }^{1} \mathrm{H}$ NMR spectrum of the H/D scrambling of $1-d_{1}$ in $T H F-d_{8}$ for $40 \mathrm{~h}$ (Scheme 4). 57\% D-incorporation on the ligand is measured. The inset is an expanded view of the diagnostic benzo[h]quinolyl region. The hydride peak appeared $(-12.65 \mathrm{ppm})$ and the red dot shows the decreased peak.

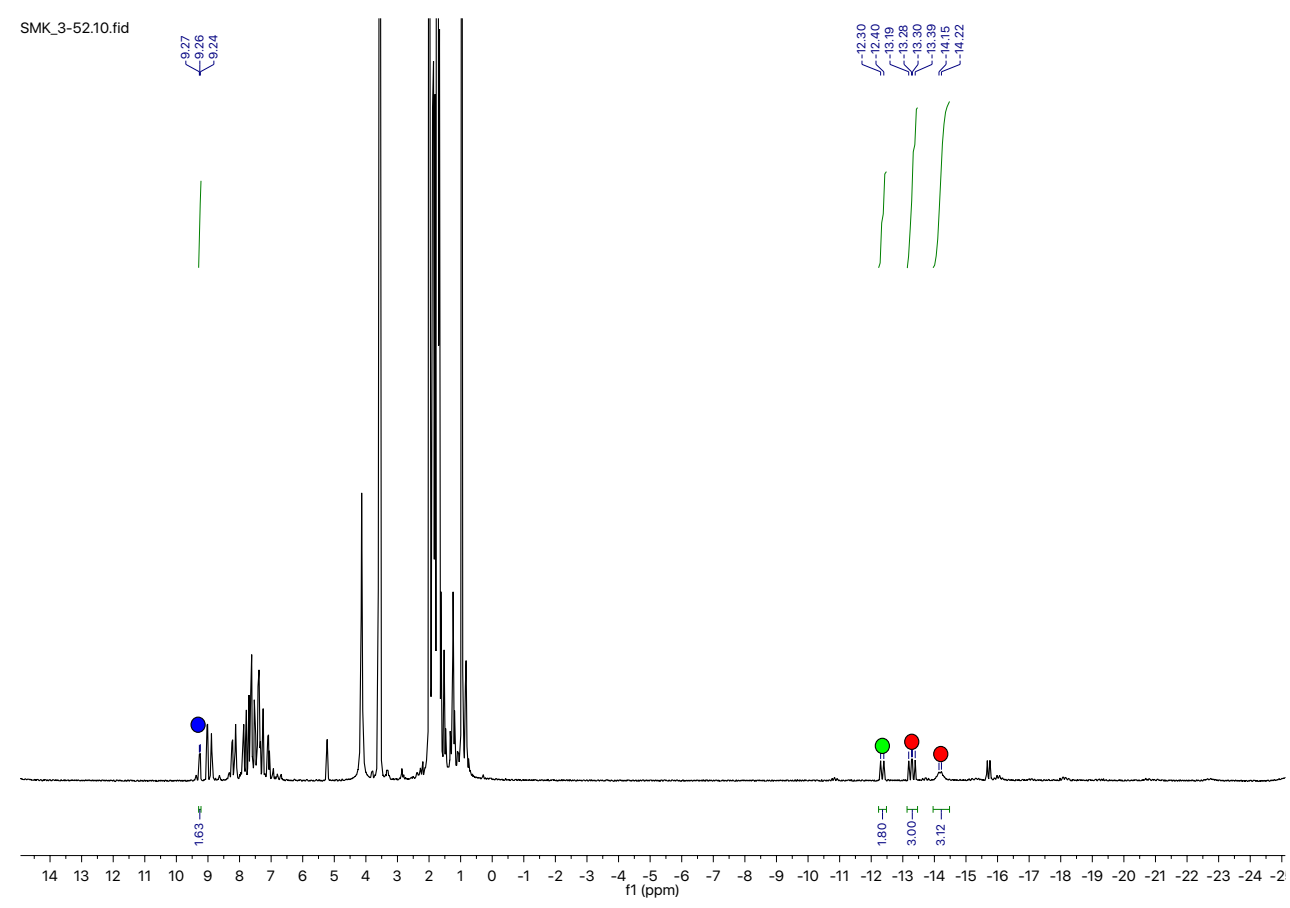

Figure S9. Representative ${ }^{1} \mathrm{H}$ NMR spectrum of the resulting product from the interaction between 4 and 4 atm $\mathrm{H}_{2}$ in THF- $d_{8}$ (Fig. $3 \mathrm{~d}$ ). The inset is an expanded view of the diagnostic hydride region. (Red dots: 5 , green dot: 2 , blue dot: benzo[h]quinoline) 


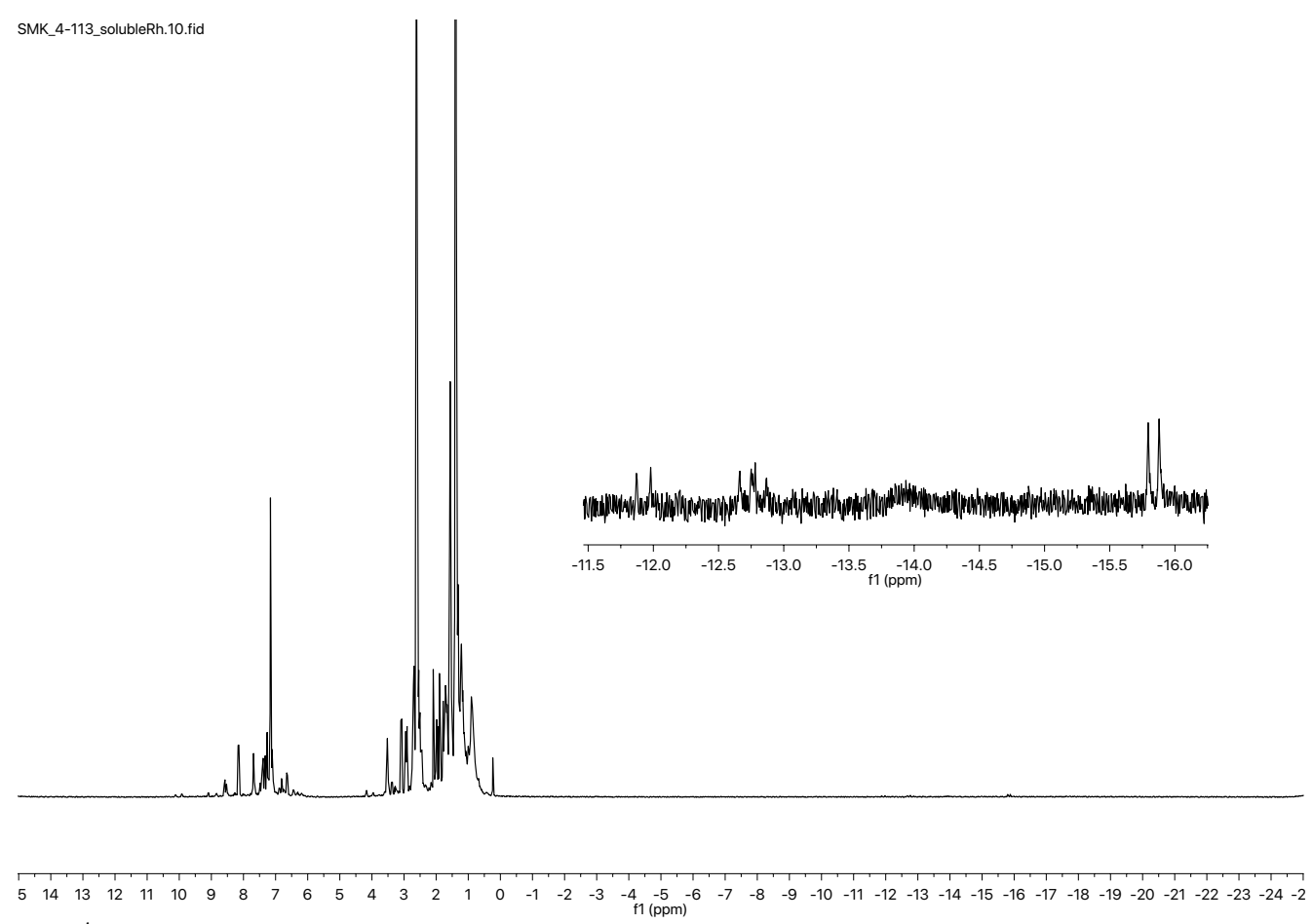

Figure S10. ${ }^{1} \mathrm{H}$ NMR spectrum of the resulting soluble Rh species after pyridine hydrogenation using the precatalyst 1 in benzene- $d_{6}$. The inset is an expanded view of the diagnostic hydride region.

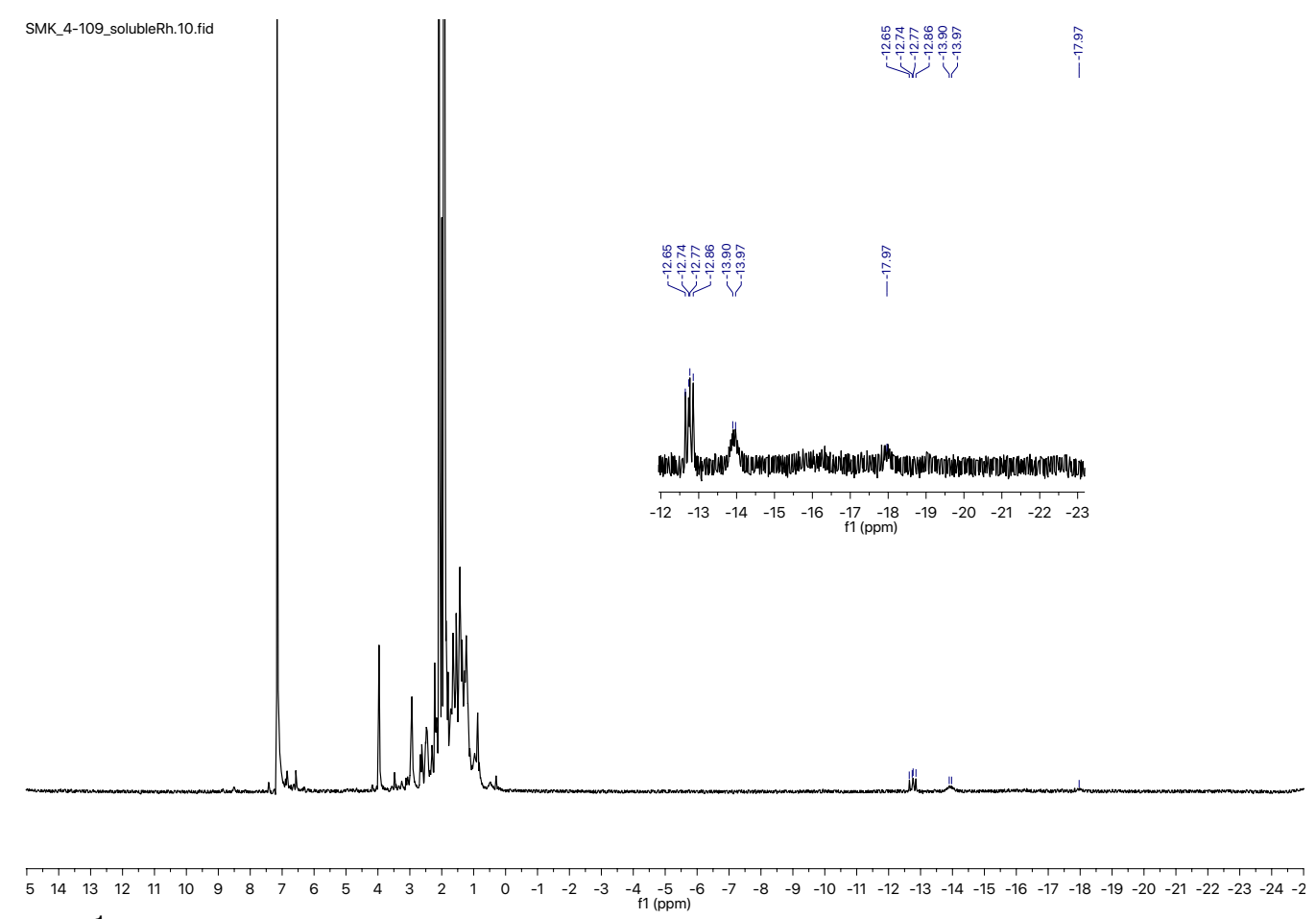

Figure S11. ${ }^{1} \mathrm{H}$ NMR spectrum of the resulting soluble Rh species after pyridine hydrogenation using the cluster 5 in benzene- $d_{6}$. The inset is an expanded view of the diagnostic hydride region. 


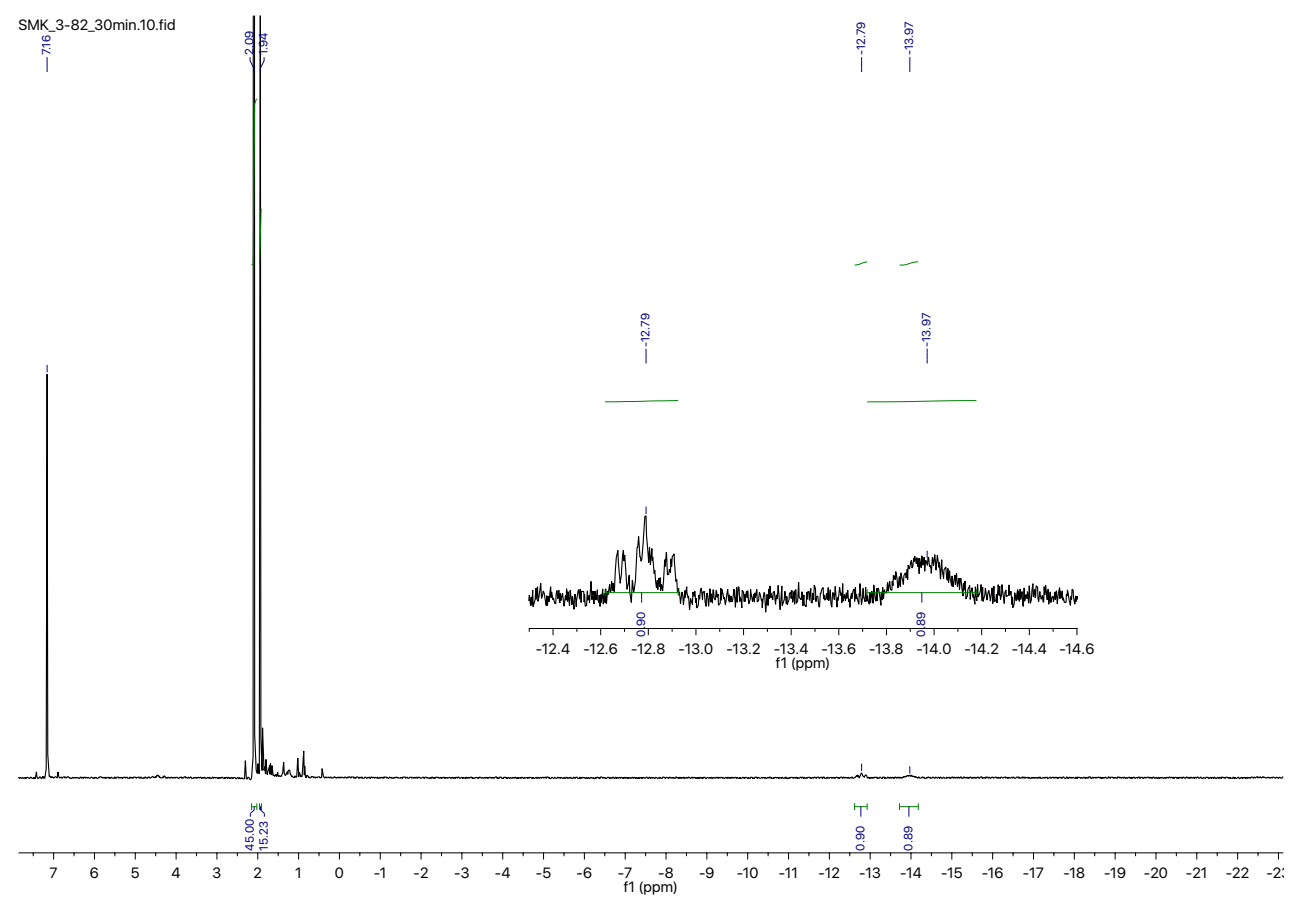

Figure S12. Representative ${ }^{1} \mathrm{H}$ NMR spectrum of the deuterium incorporation into 5 in benzene$d_{6}$ for 30 min under 4 atm $D_{2} .70 \%$ D-incorporation is measured.

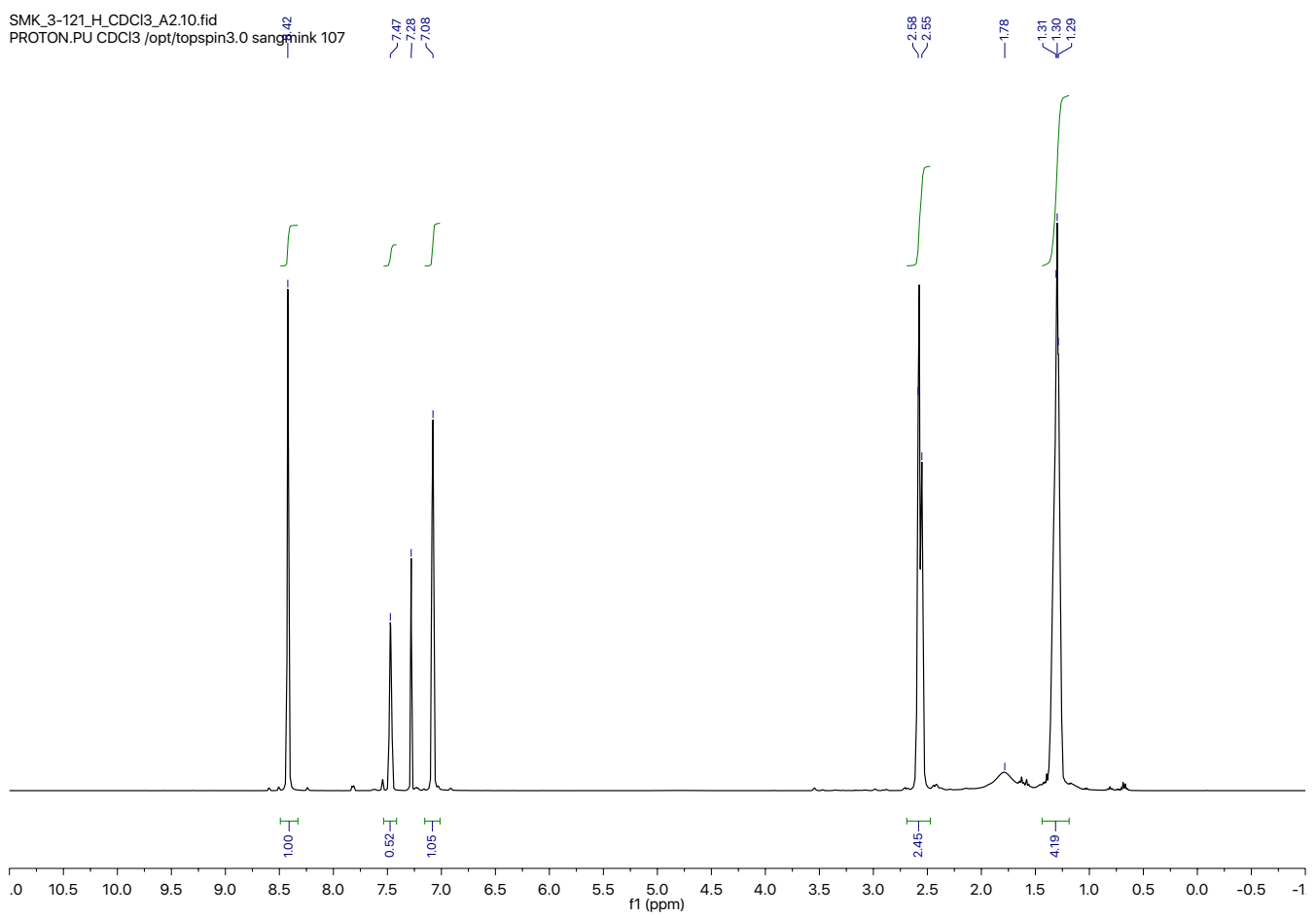

Figure S13. Representative ${ }^{1} \mathrm{H}$ NMR spectrum of the catalytic deuteration of pyridine in $\mathrm{CDCl}_{3}$ (Scheme 2). 


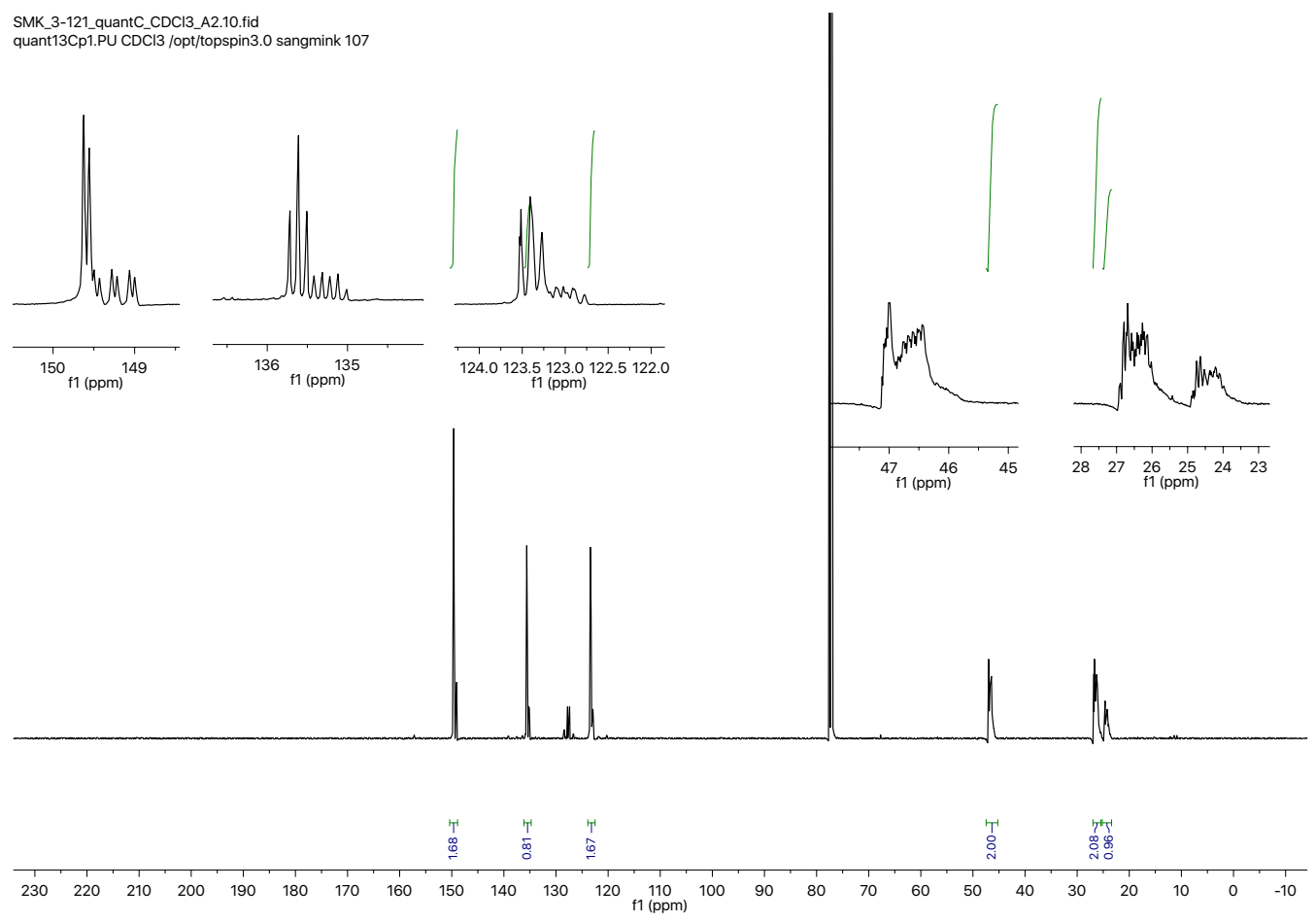

Figure S14. Representative quantitative ${ }^{13} \mathrm{C}\left\{{ }^{1} \mathrm{H}\right\}$ NMR spectrum of the catalytic deuteration of pyridine in $\mathrm{CDCl}_{3}$ (Scheme 2). The insets are expanded views of each peaks of pyridine and piperidine. 


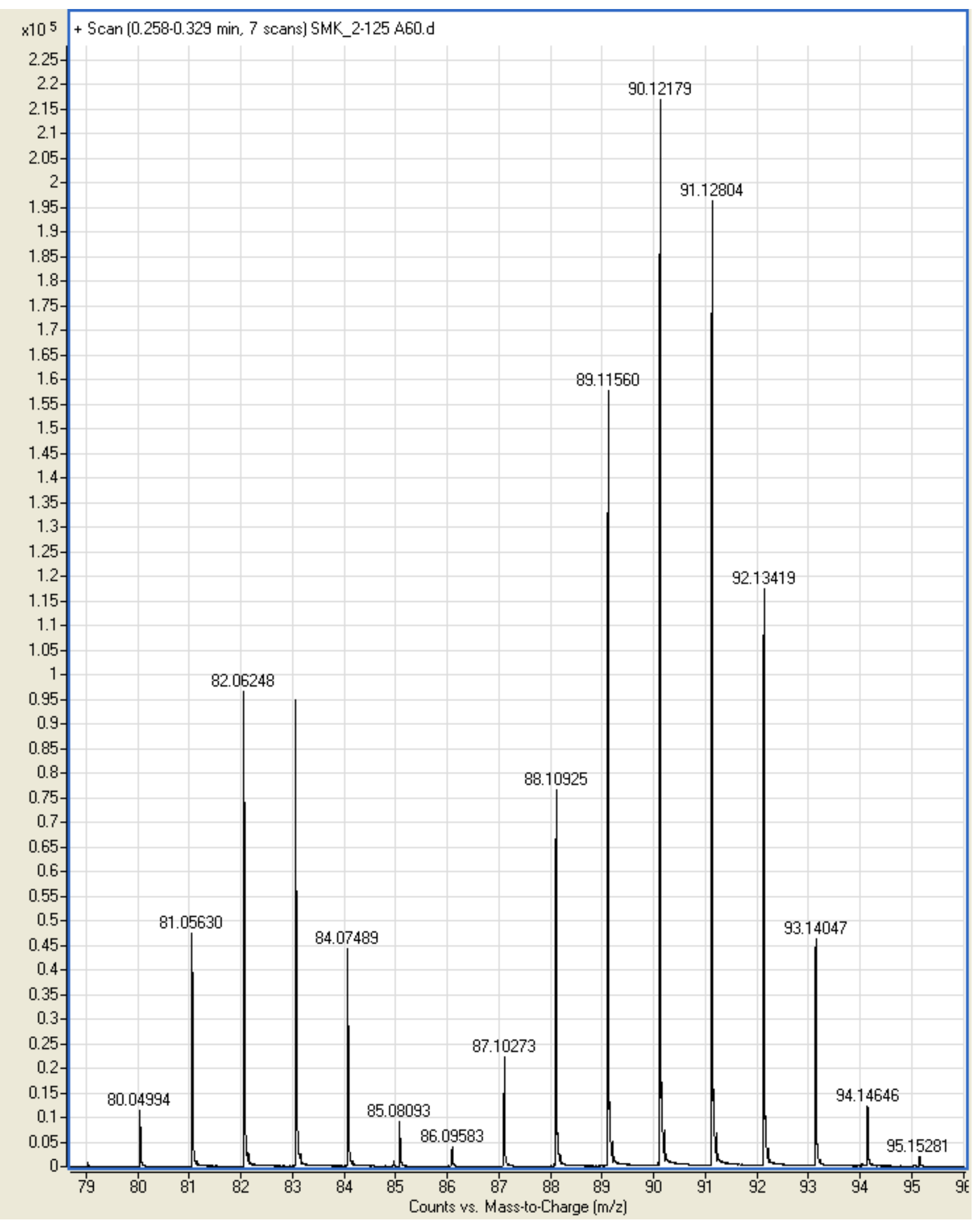

Figure S15. Representative mass spectrum of the mixture of the catalytic deuteration of pyridine (Scheme 2). 


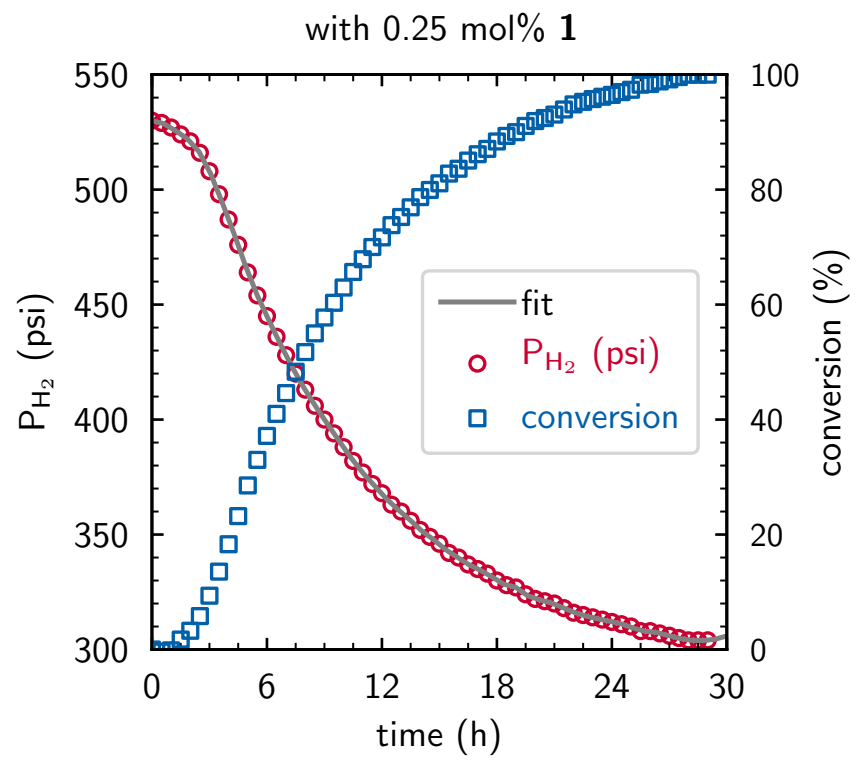

Figure S16. Kinetic profile using $0.25 \mathrm{~mol} \%$ of 1 as a catalyst with $1.0 \mathrm{~mL}$ pyridine and $530 \mathrm{psi}$ $\mathrm{H}_{2}$. Time (h) vs pressure of $\mathrm{H}_{2}$ (psi).

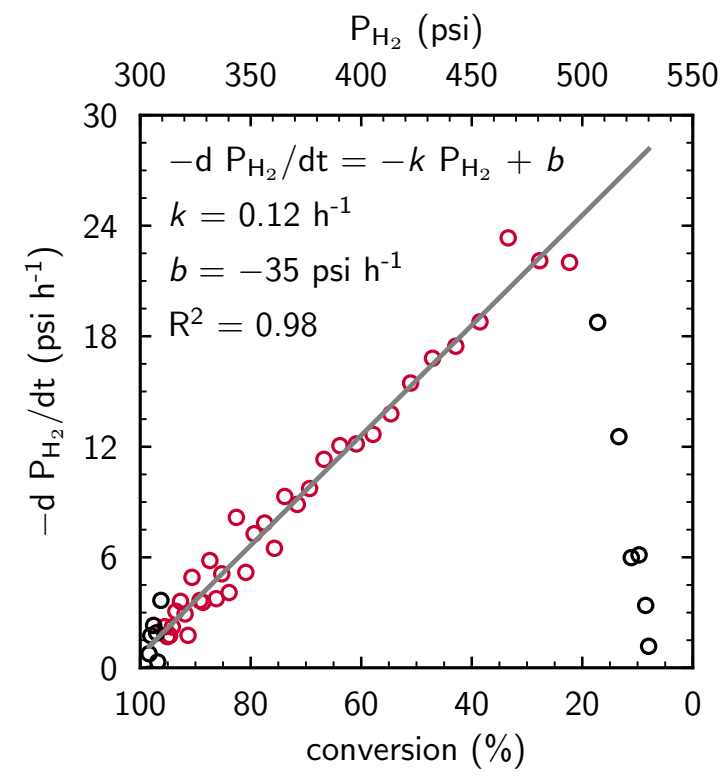

Figure S17. Kinetic profile using $0.25 \mathrm{~mol} \%$ of 1 as a catalyst with $1.0 \mathrm{~mL}$ pyridine and $530 \mathrm{psi}$ $\mathrm{H}_{2}$. Conversion (\%) or pressure of $\mathrm{H}_{2}$ (psi) vs reaction rate $\left(-\mathrm{dP}_{\mathrm{H} 2} / \mathrm{dt}\right.$, unit of $\left.p s i h^{-1}\right)$. 


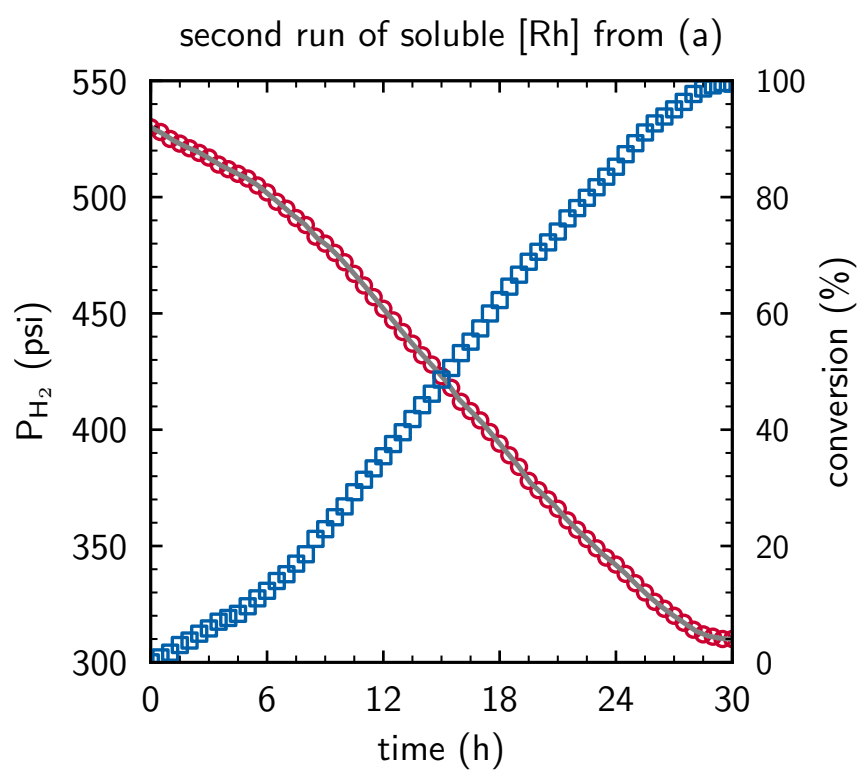

Figure S18. Kinetic profile of the 2nd cycle of run a in Fig 4. Time (h) vs pressure of $\mathrm{H}_{2}(\mathrm{psi})$.

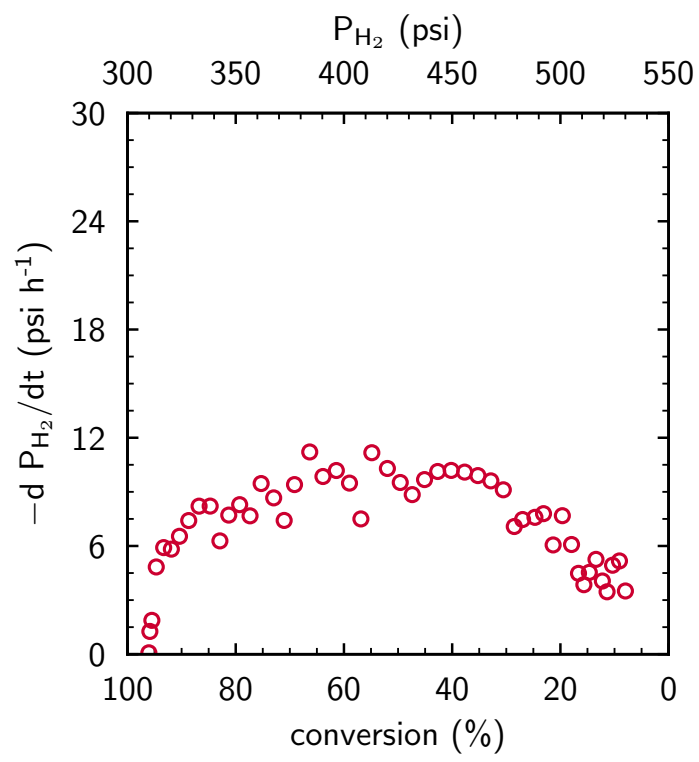

Figure S19. Kinetic profile of the 2nd cycle of run a in Fig 4. Conversion (\%) or pressure of $\mathrm{H}_{2}$ (psi) vs reaction rate $\left(-\mathrm{dP}_{\mathrm{H} 2} / \mathrm{dt}\right.$, unit of $\left.\mathrm{psi} \mathrm{h}^{-1}\right)$. 


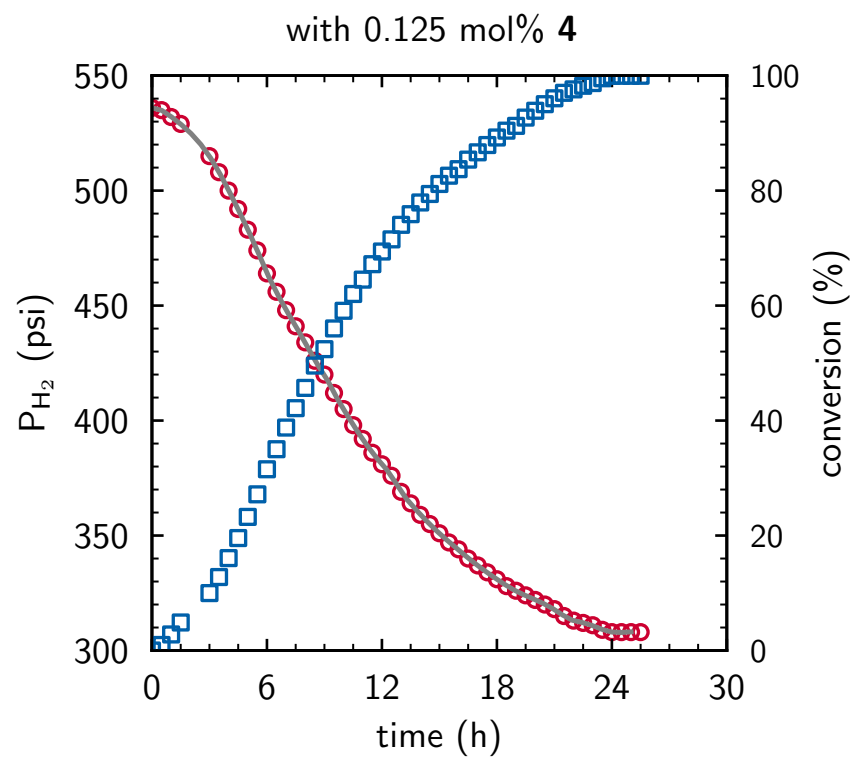

Figure S20. Kinetic profile using $0.125 \mathrm{~mol} \%$ of 4 as a catalyst with $1.0 \mathrm{~mL}$ pyridine and 530 psi $\mathrm{H}_{2}$. Time (h) vs pressure of $\mathrm{H}_{2}$ (psi).

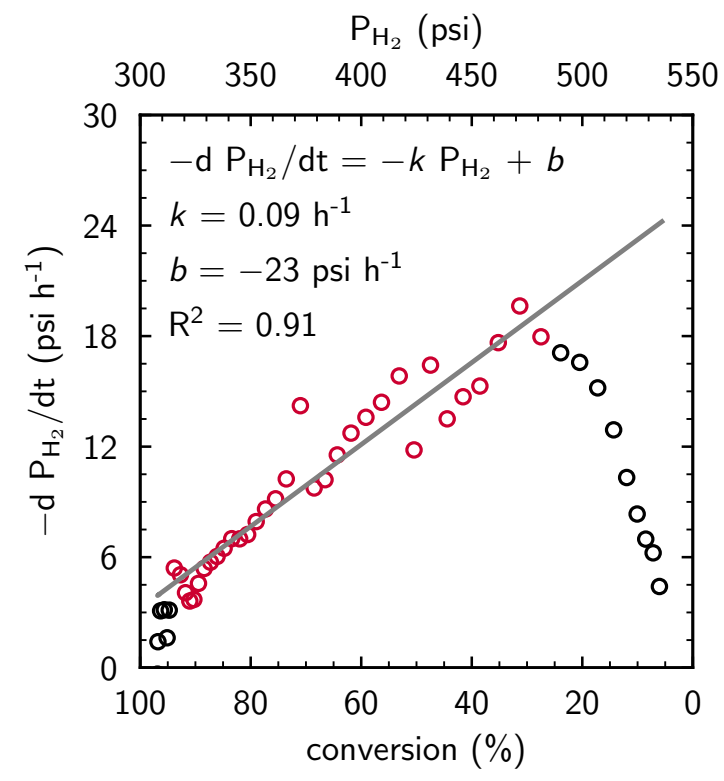

Figure S21. Kinetic profile using $0.125 \mathrm{~mol} \%$ of 4 as a catalyst with $1.0 \mathrm{~mL}$ pyridine and 530 psi $\mathrm{H}_{2}$. Conversion (\%) or pressure of $\mathrm{H}_{2}(\mathrm{psi})$ vs reaction rate $\left(-\mathrm{dP}_{\mathrm{H} 2} / \mathrm{dt}\right.$, unit of $\left.\mathrm{psi}^{-1}\right)$. 


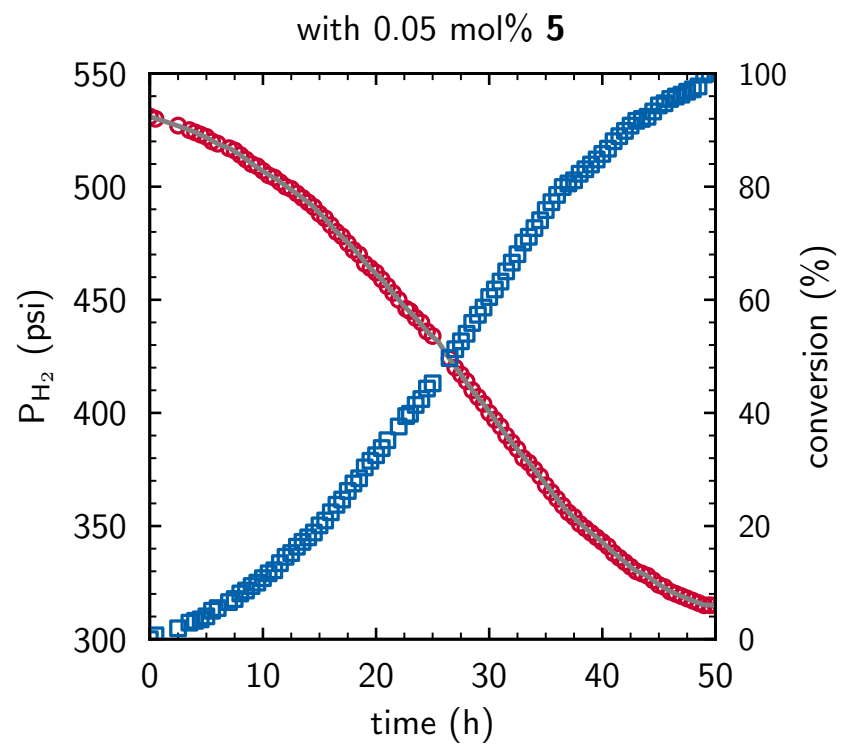

Figure S22. Kinetic profile using $0.05 \mathrm{~mol} \%$ of 5 as a catalyst with $1.0 \mathrm{~mL}$ pyridine and $530 \mathrm{psi}$ $\mathrm{H}_{2}$. Time (h) vs pressure of $\mathrm{H}_{2}$ (psi).

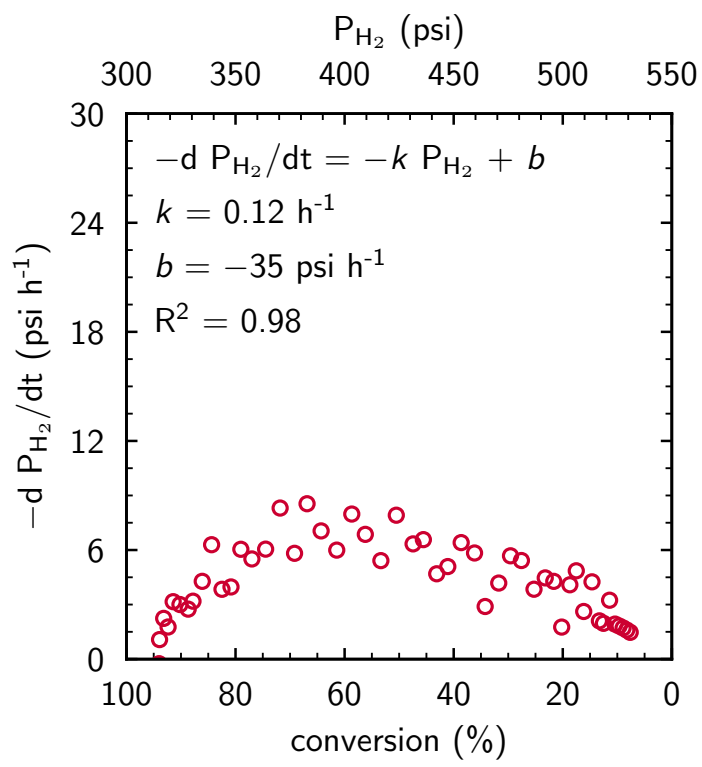

Figure S23. Kinetic profile using $0.05 \mathrm{~mol} \%$ of 5 as a catalyst with $1.0 \mathrm{~mL}$ pyridine and $530 \mathrm{psi}$ $\mathrm{H}_{2}$. Conversion (\%) or pressure of $\mathrm{H}_{2}(\mathrm{psi})$ vs reaction rate $\left(-\mathrm{dP}_{\mathrm{H} 2} / \mathrm{dt}\right.$, unit of $\left.\mathrm{psi} \mathrm{h}^{-1}\right)$. 


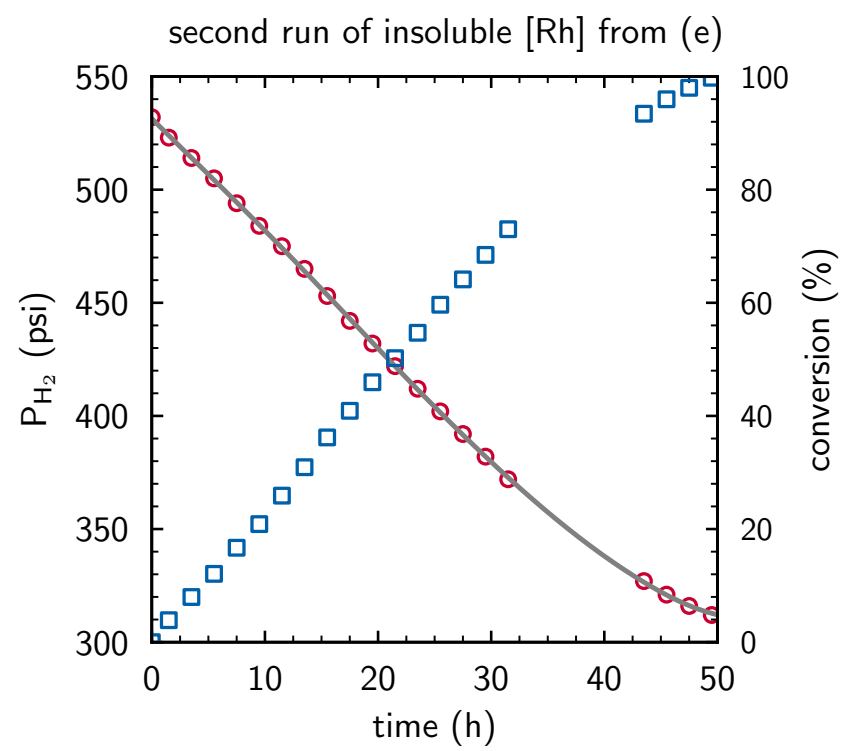

Figure S24. Kinetic profile of the 2 nd cycle of run e in Fig 4. Time (h) vs pressure of $\mathrm{H}_{2}$ (psi).

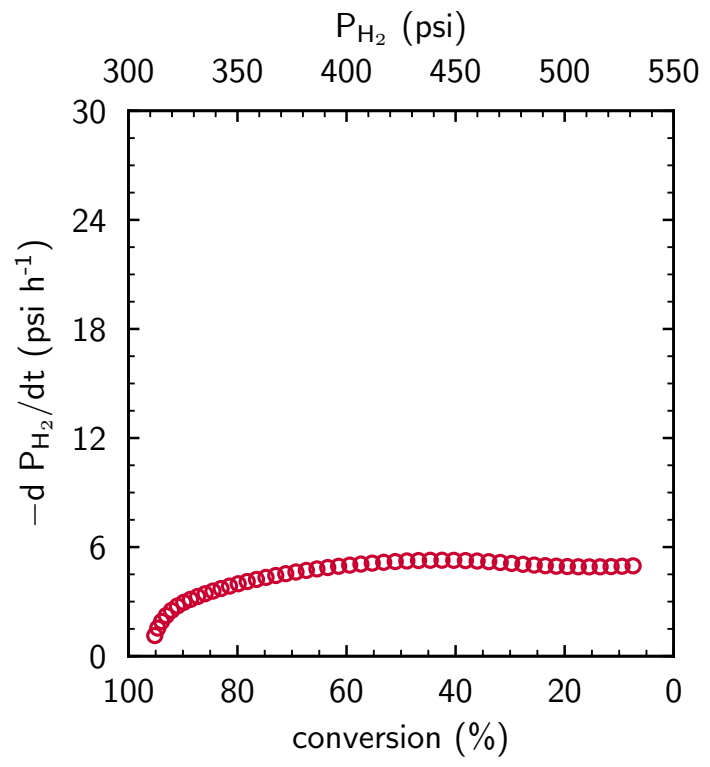

Figure S25. Kinetic profile of the 2nd cycle of run e in Fig 4. Conversion (\%) or pressure of $\mathrm{H}_{2}$ (psi) vs reaction rate $\left(-\mathrm{dP}_{\mathrm{H} 2} / \mathrm{dt}\right.$, unit of $\left.\mathrm{psi}^{-1}\right)$. 


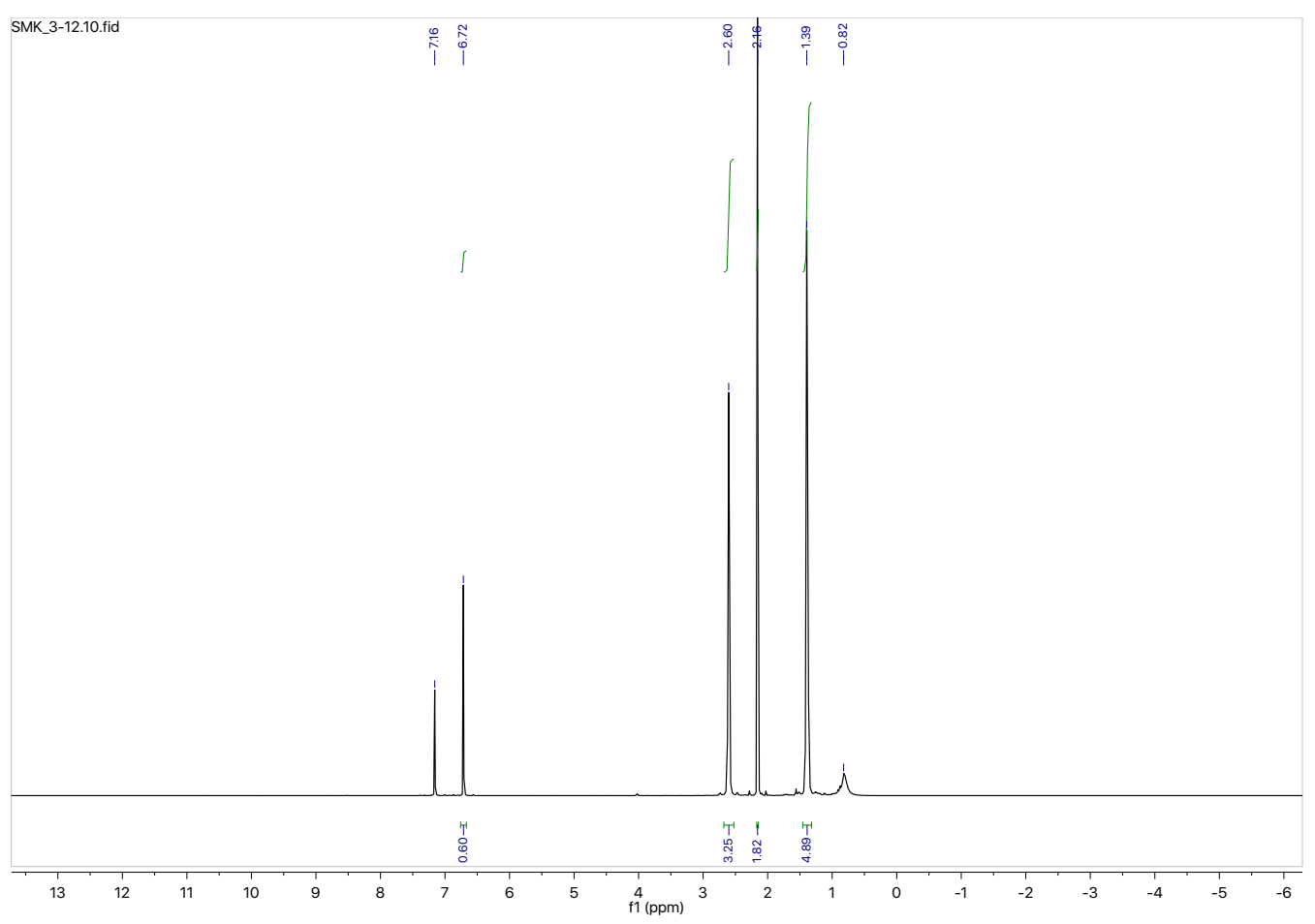

Figure S26. ${ }^{1} \mathrm{H}$ NMR spectrum of a crude product of $3 \mathrm{a}$ in benzene- $d_{6}$. Mesitylene $(6.72,2.16$ ppm) was used as an internal standard.

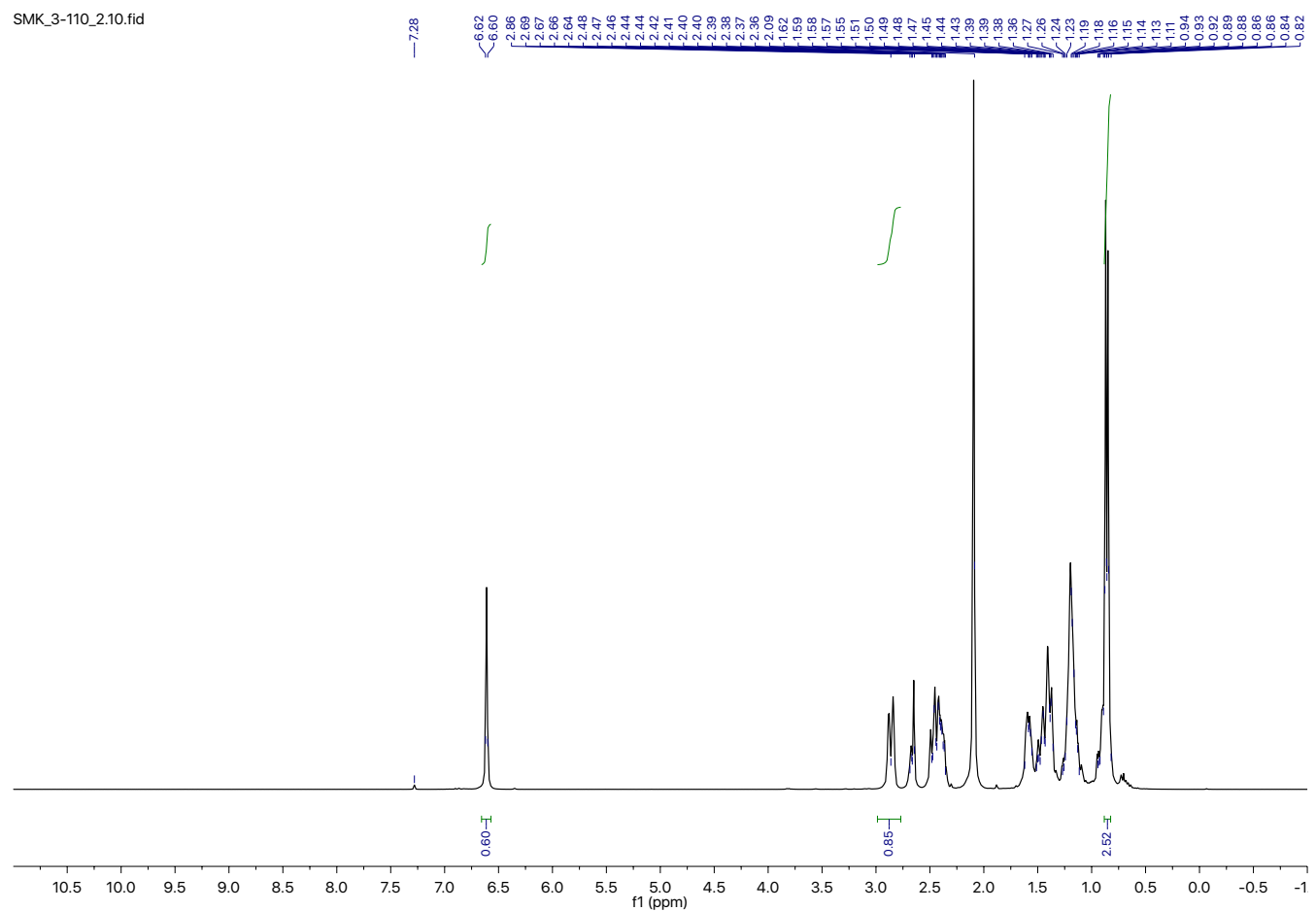

Figure S27. ${ }^{1} \mathrm{H}$ NMR spectrum of a crude product of $3 \mathrm{~b}$ in $\mathrm{CDCl}_{3}$. Mesitylene was used as an internal standard. 


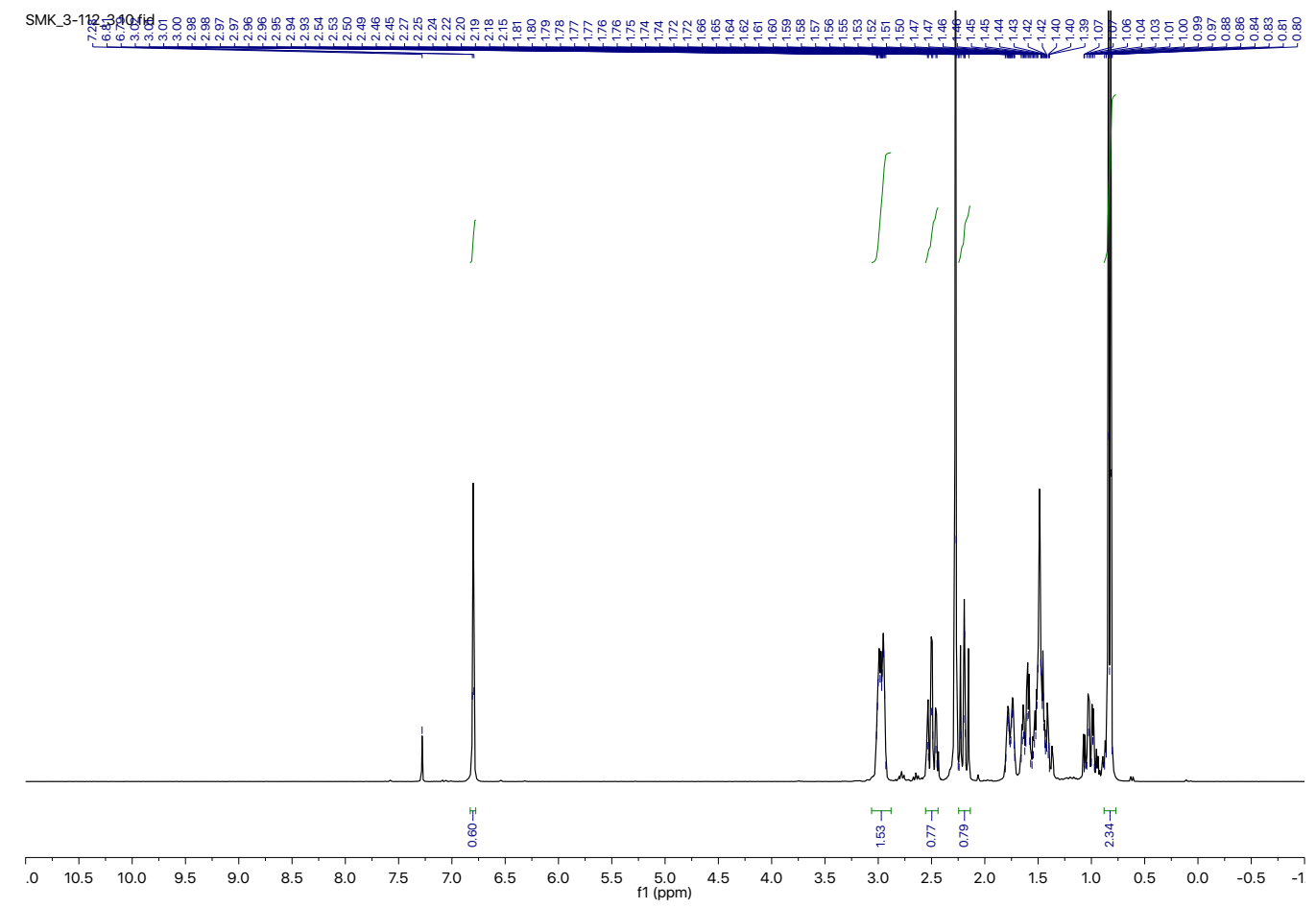

Figure S28. ${ }^{1} \mathrm{H}$ NMR spectrum of a crude product of $3 \mathrm{C}$ in $\mathrm{CDCl}_{3}$. Mesitylene was used as an internal standard.

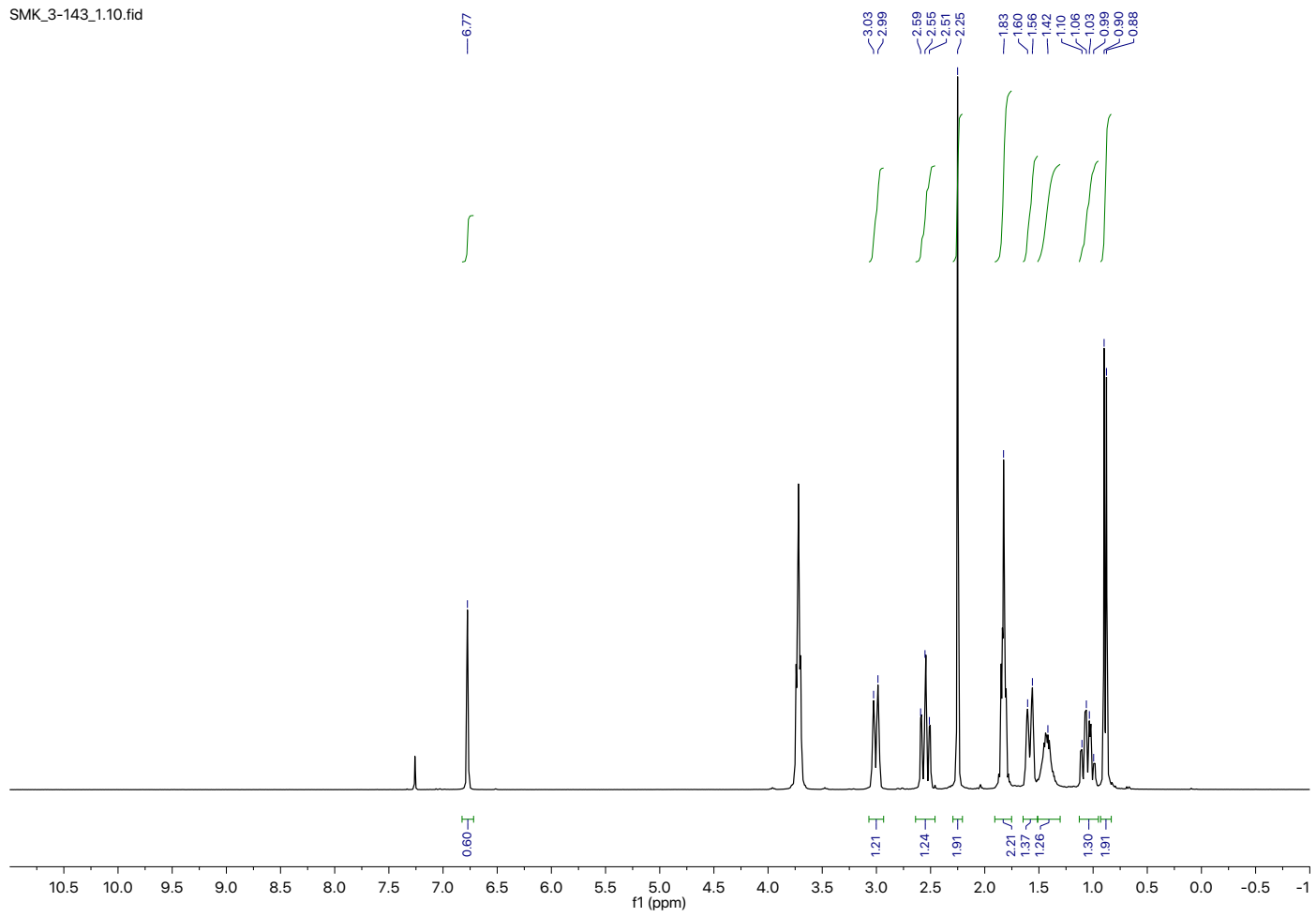

Figure S29. ${ }^{1} \mathrm{H}$ NMR spectrum of a crude product of $3 \mathrm{~d}$ in $\mathrm{CDCl}_{3}$. Mesitylene was used as an internal standard. 


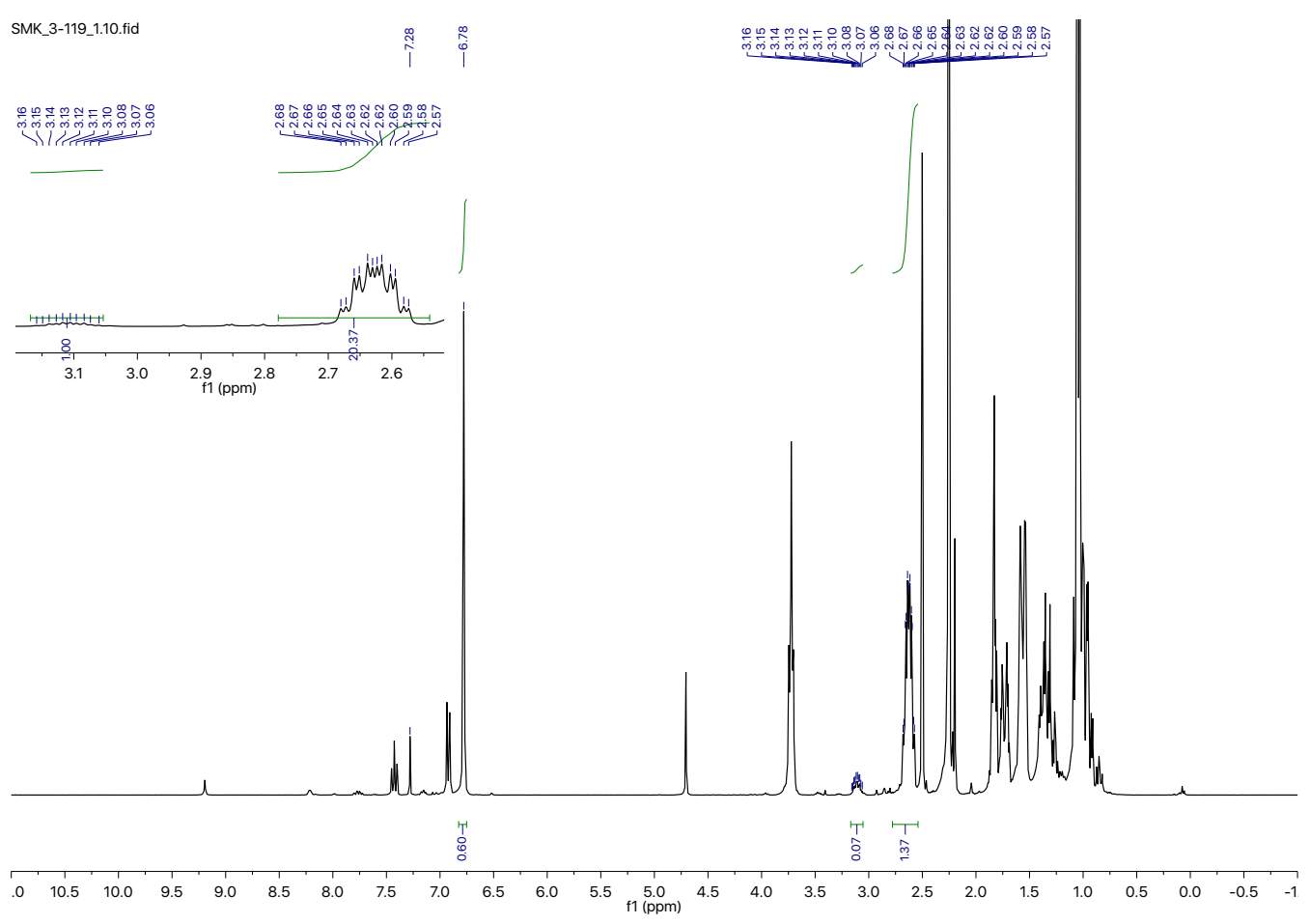

Figure S30. ${ }^{1} \mathrm{H}$ NMR spectrum of a crude product of $3 \mathrm{e}$ in $\mathrm{CDCl}_{3}$. Mesitylene was used as an internal standard. The inset is an expanded view of the diagnostic regions of both cis-(2.63 ppm) and trans(3.11ppm) isomers.

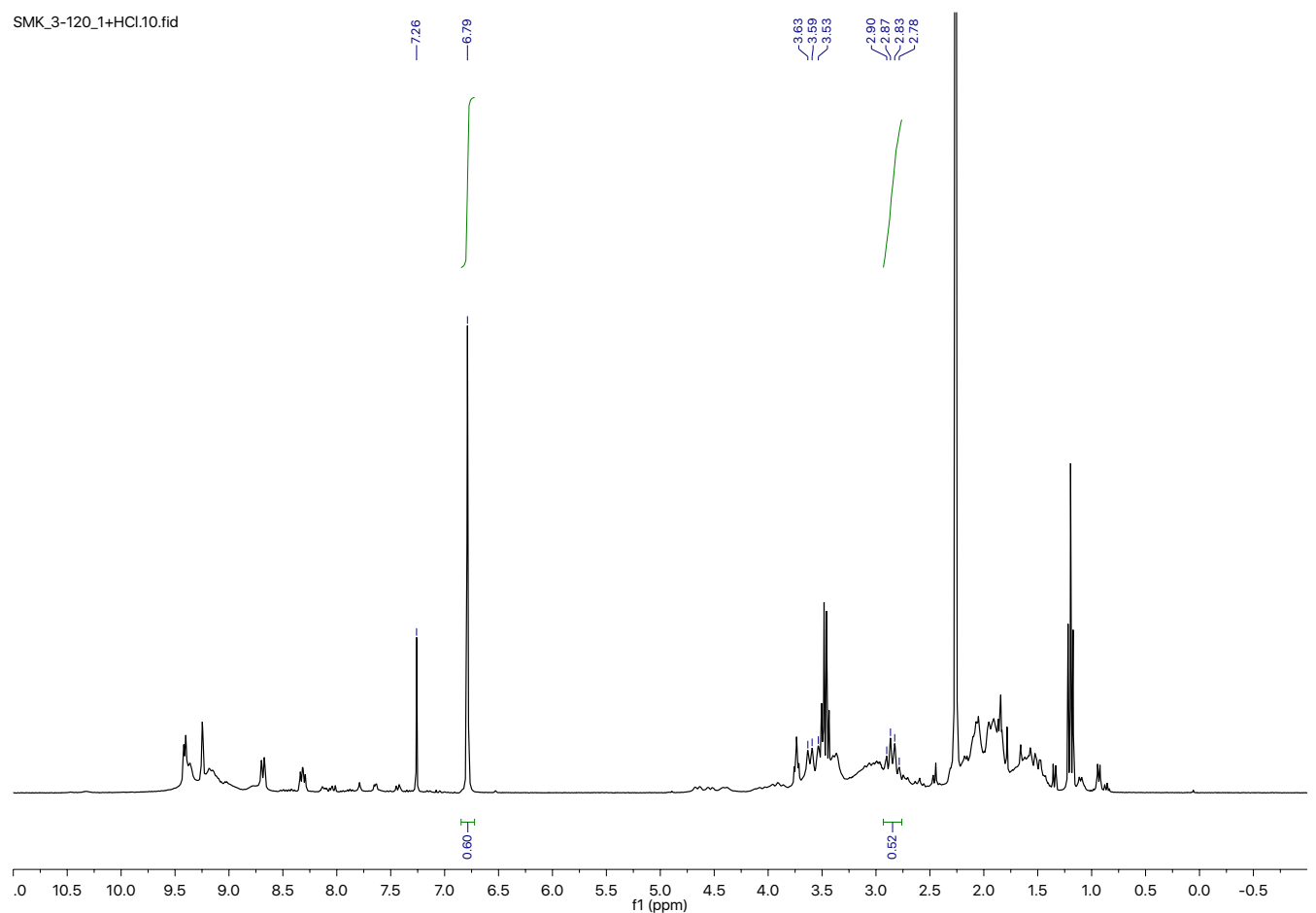

Figure S31. ${ }^{1} \mathrm{H}$ NMR spectrum of a crude product of $3 \mathrm{f}$ treated with excess $\mathrm{HCl}$ in $\mathrm{Et}_{2} \mathrm{O}$ in $\mathrm{CDCl}_{3}$. Mesitylene was used as an internal standard. 


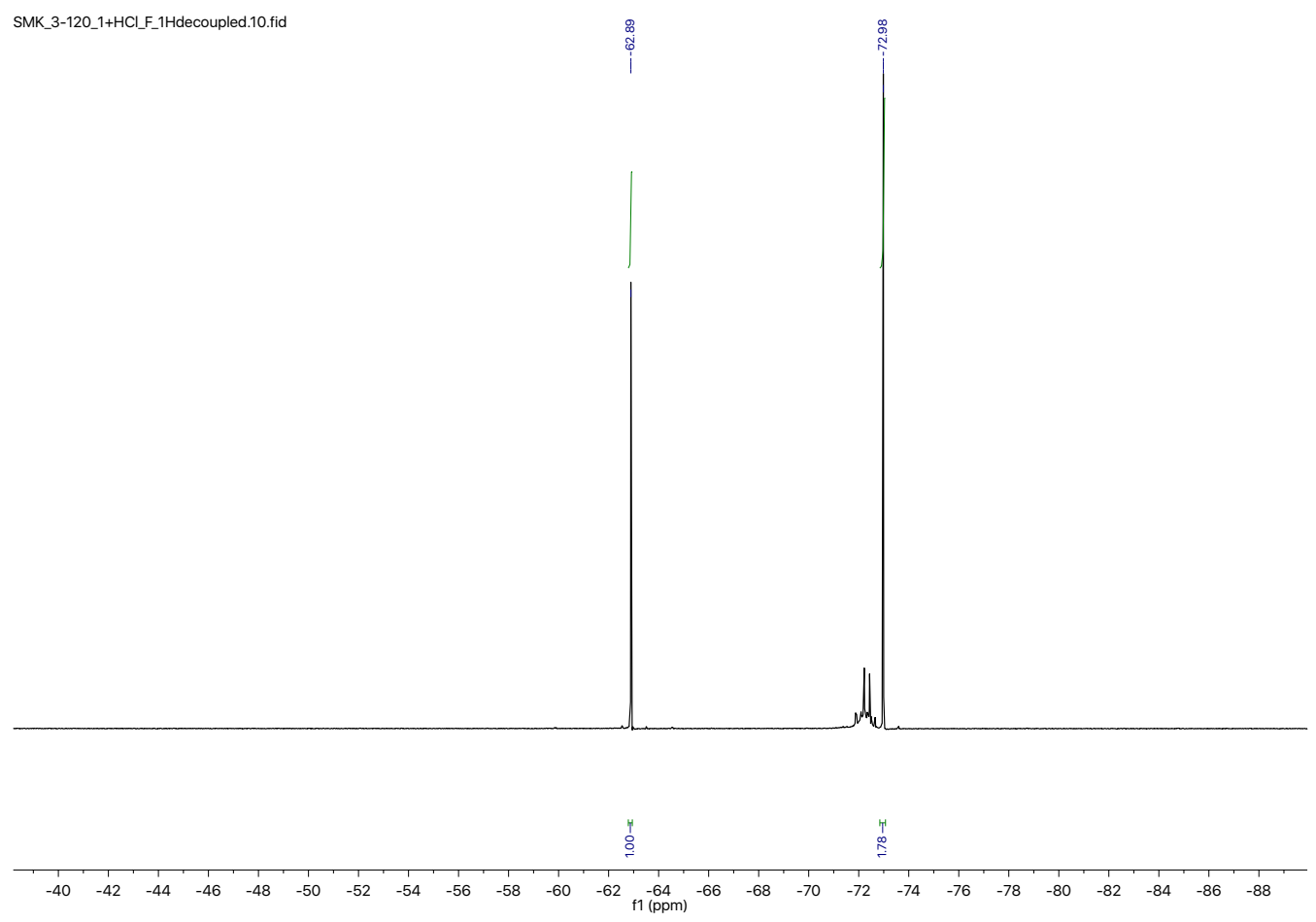

Figure S32. ${ }^{19} \mathrm{~F}$ NMR spectrum of a crude product of $\mathbf{3 f}$ treated with excess $\mathrm{HCl}$ in $\mathrm{Et}_{2} \mathrm{O}$ in $\mathrm{CDCl}_{3}$. The product signal appears at $-72.98 \mathrm{ppm}$.

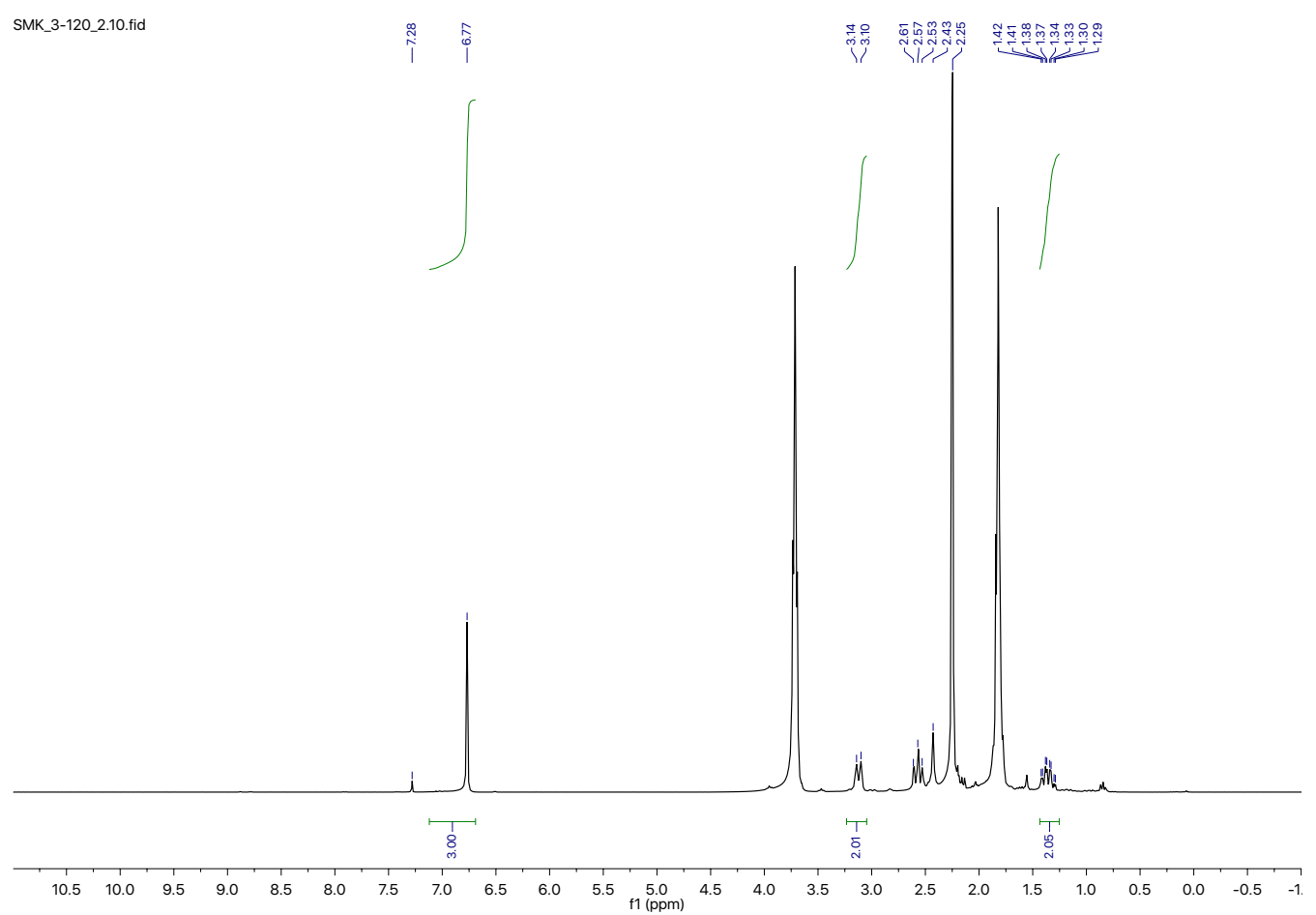

Figure S33. ${ }^{1} \mathrm{H}$ NMR spectrum of a crude product of $3 \mathrm{~g}$ in $\mathrm{CDCl}_{3}$. Mesitylene was used as an internal standard. 


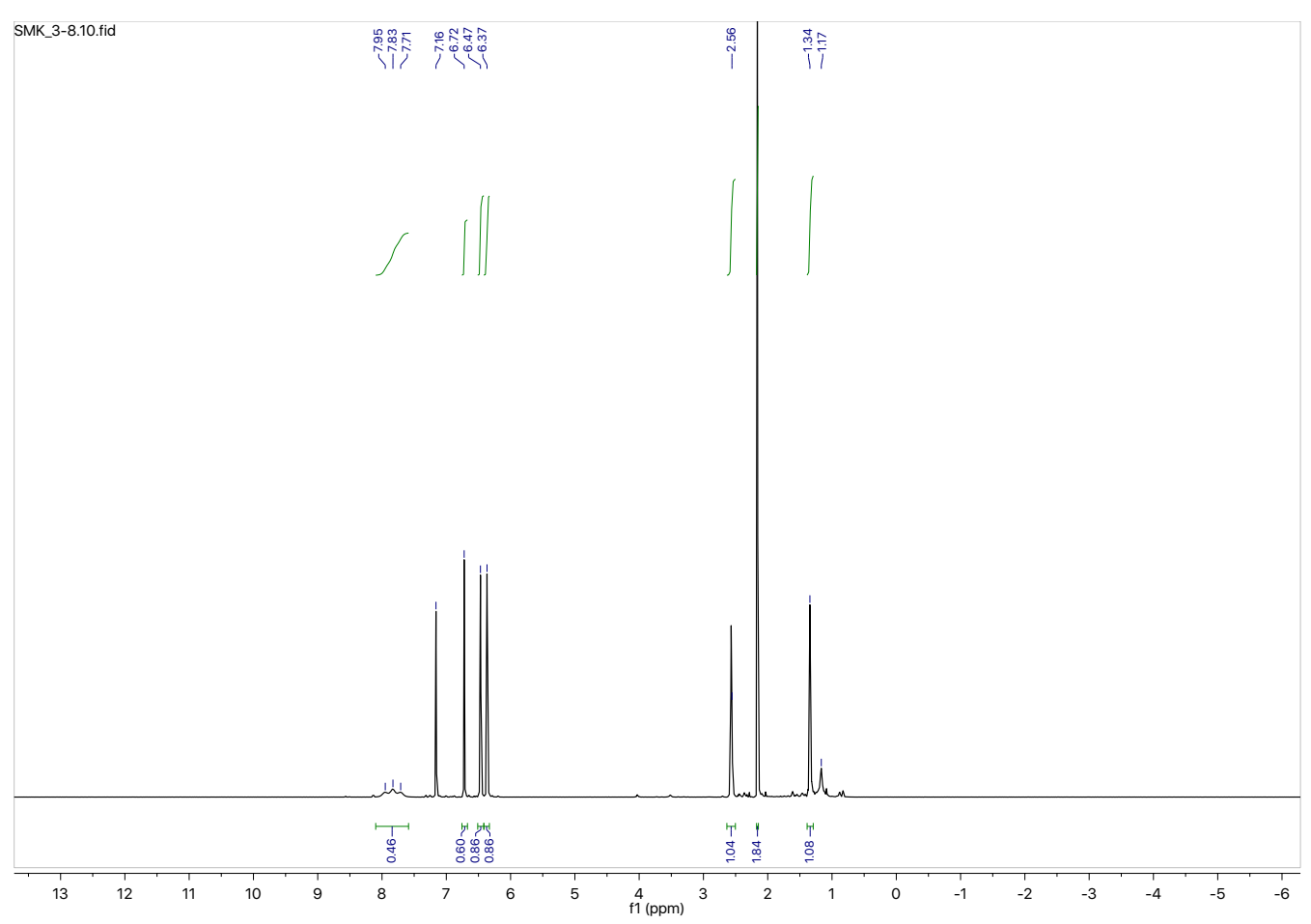

Figure S34. ${ }^{1} \mathrm{H}$ NMR spectrum of a crude product of $3 \mathrm{~h}$ by the method $\mathrm{A}$ in benzene- $d_{6}$. Mesitylene was used as an internal standard.

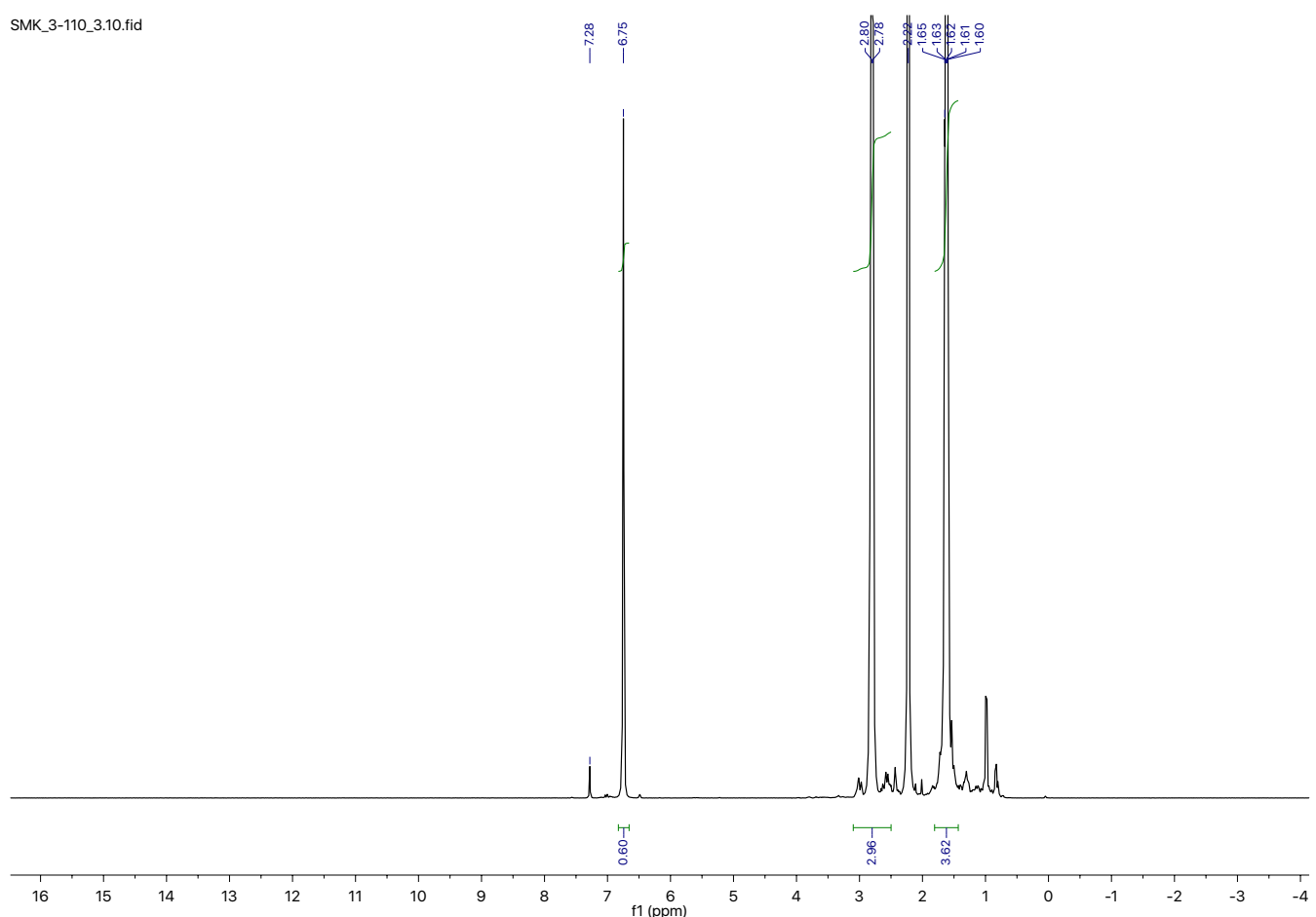

Figure S35. ${ }^{1} \mathrm{H}$ NMR spectrum of a crude product of $3 \mathrm{~h}$ by the method $\mathrm{B}$ in $\mathrm{CDCl}_{3}$. Mesitylene was used as an internal standard. 


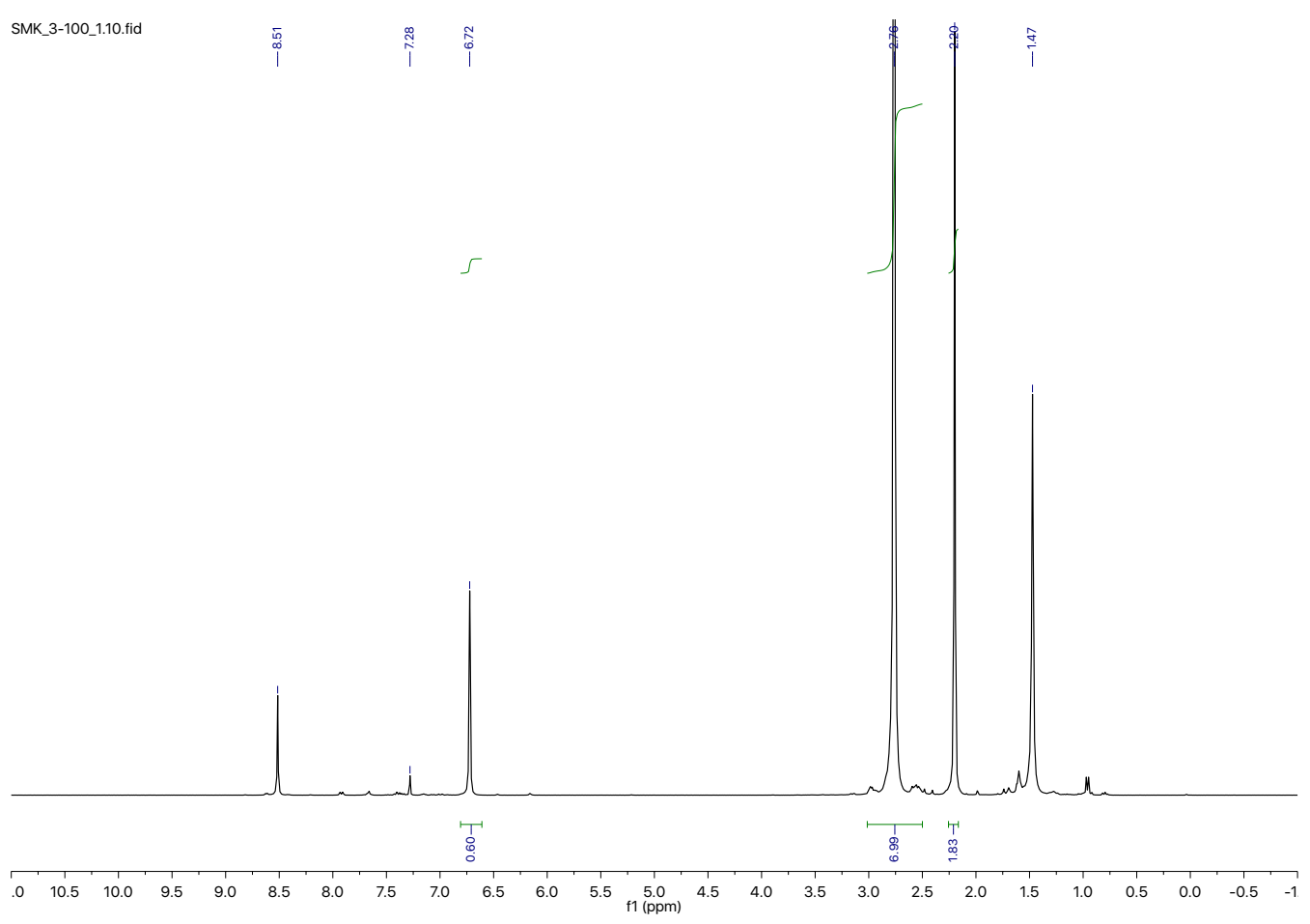

Figure S36. ${ }^{1} \mathrm{H}$ NMR spectrum of a crude product of $3 \mathrm{i}$ in $\mathrm{CDCl}_{3}$. Mesitylene was used as an internal standard.

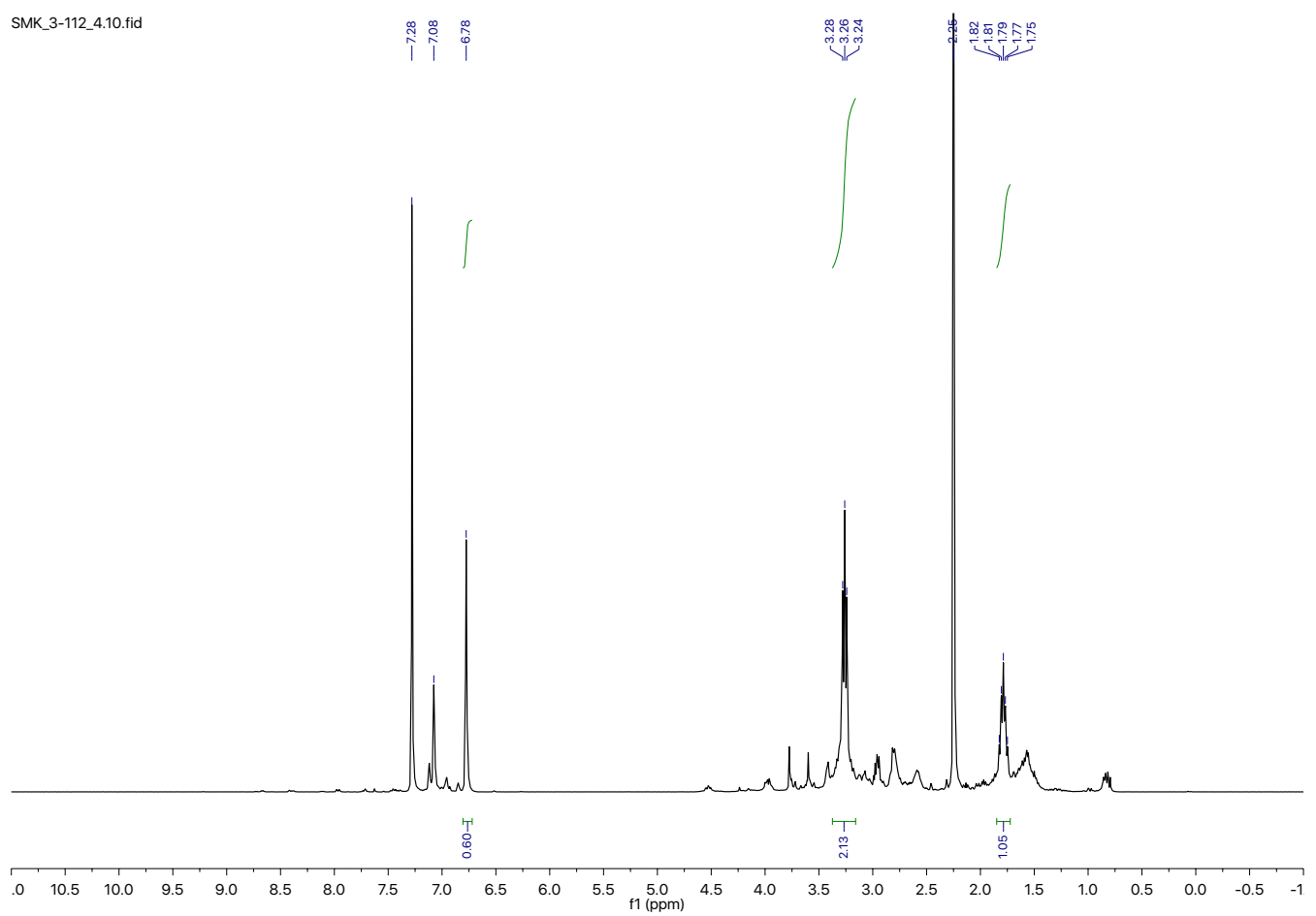

Figure S37. ${ }^{1} \mathrm{H}$ NMR spectrum of a crude product of $3 \mathbf{j}$ in $\mathrm{CDCl}_{3}$. Mesitylene was used as an internal standard. 


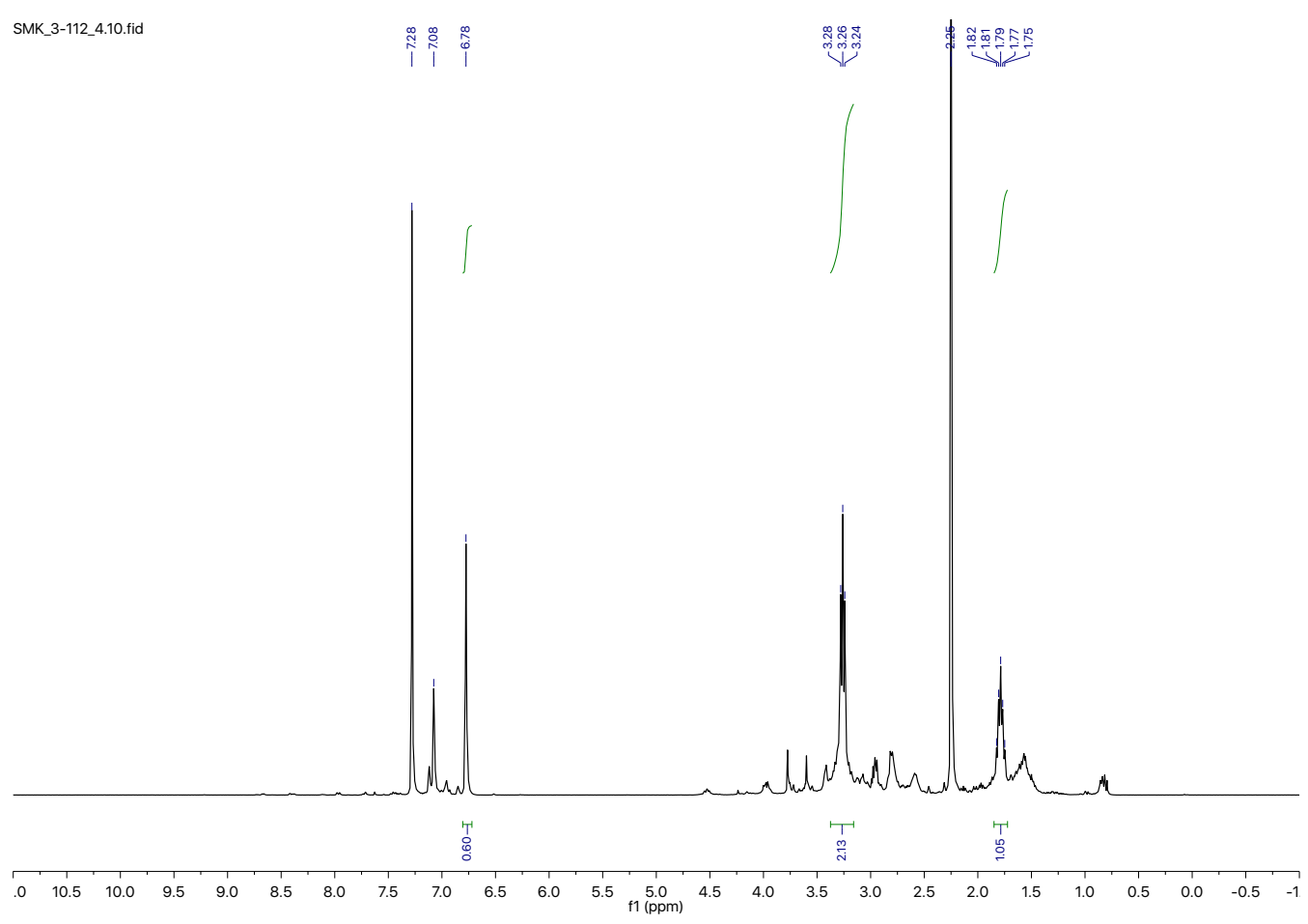

Figure S38. ${ }^{1} \mathrm{H}$ NMR spectrum of a crude product of $3 \mathbf{k}$ by the method $\mathrm{A}$ in benzene- $d_{6}$. Mesitylene was used as an internal standard.

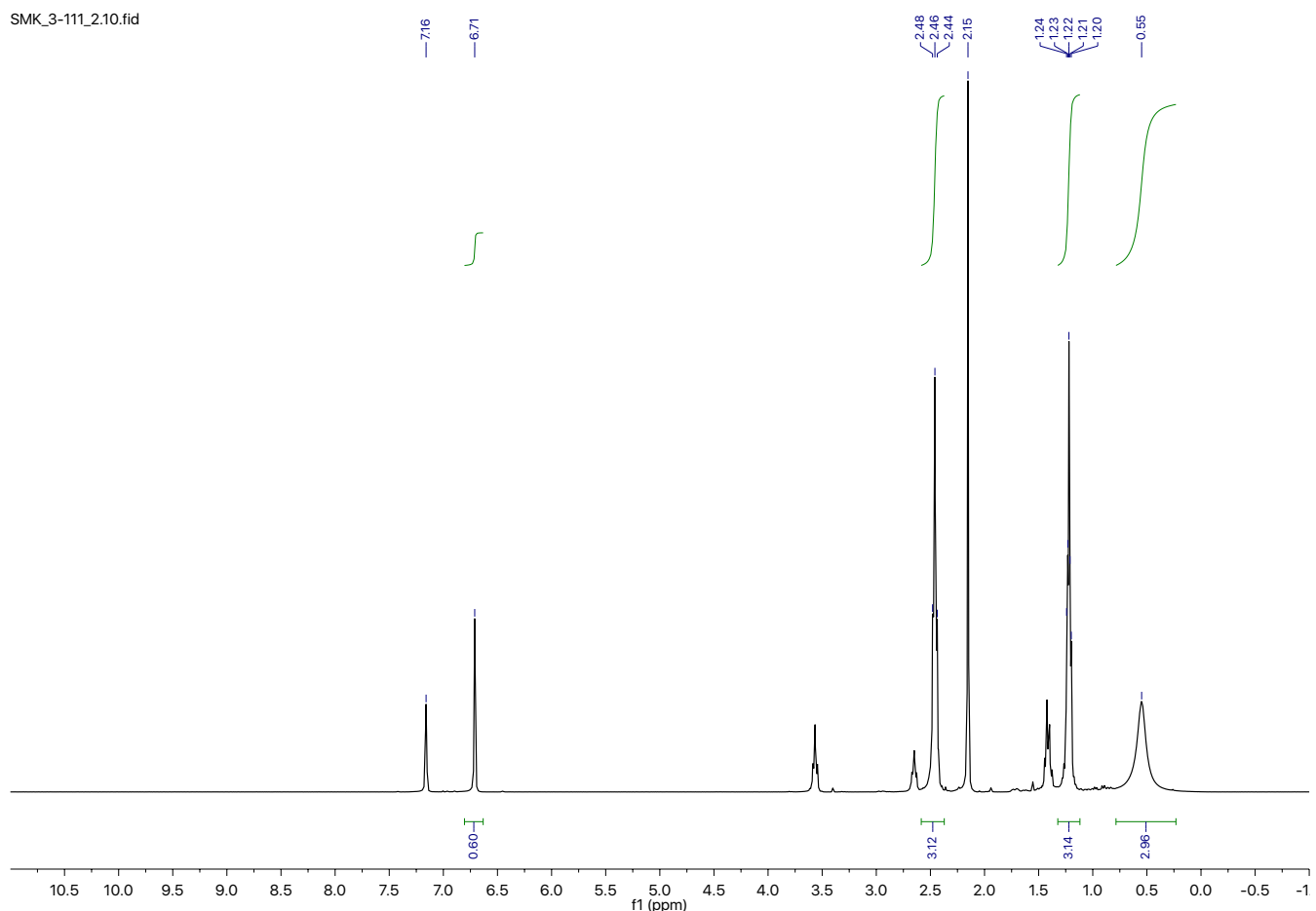

Figure S39. ${ }^{1} \mathrm{H}$ NMR spectrum of a crude product of 3 I by the method B in benzene- $d_{6}$. Mesitylene was used as an internal standard. 


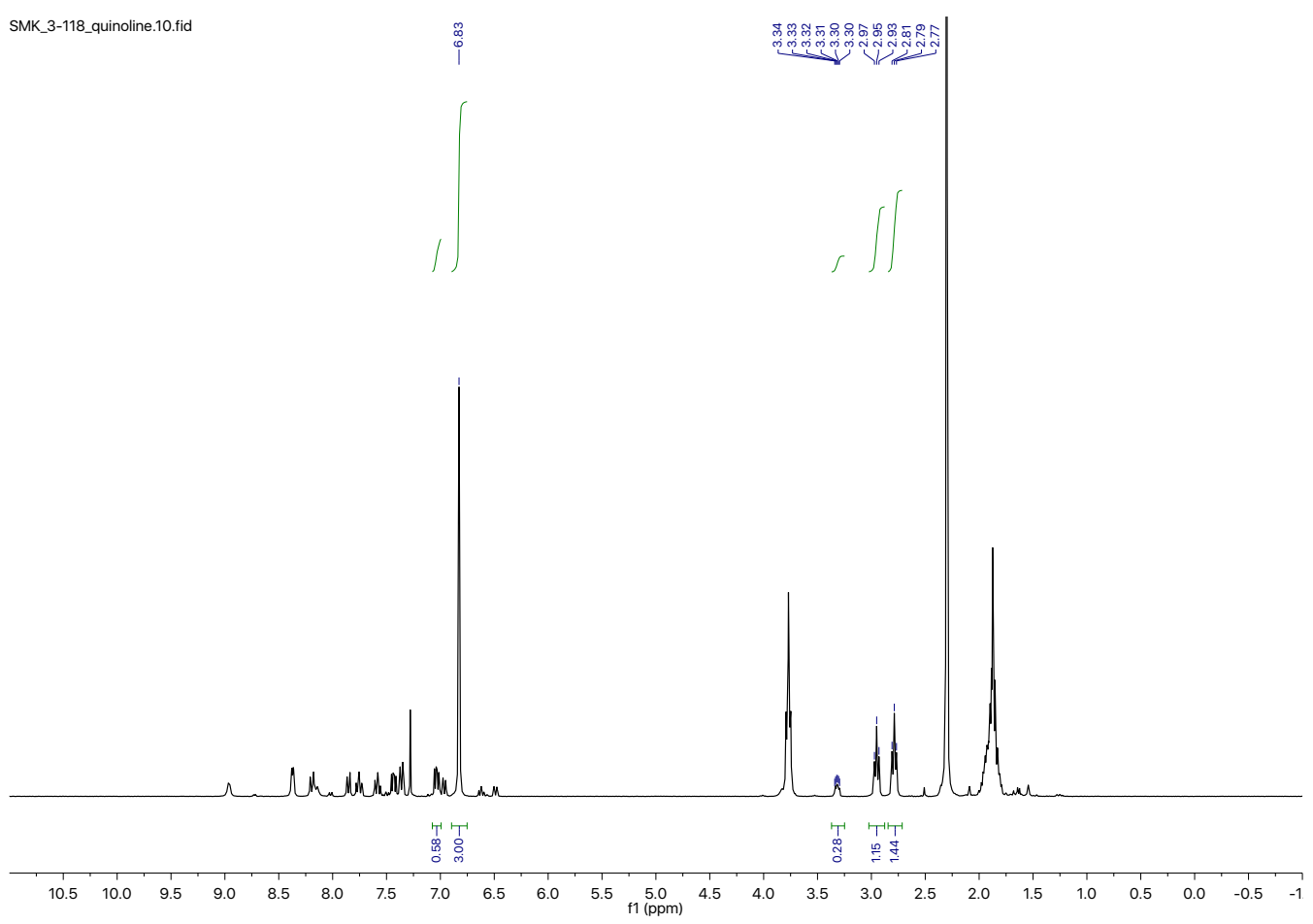

Figure S40. ${ }^{1} \mathrm{H}$ NMR spectrum of a crude mixture of $3 \mathrm{~s}$ and $3 \mathrm{t}$ in $\mathrm{CDCl}_{3}$. Mesitylene was used as an internal standard.

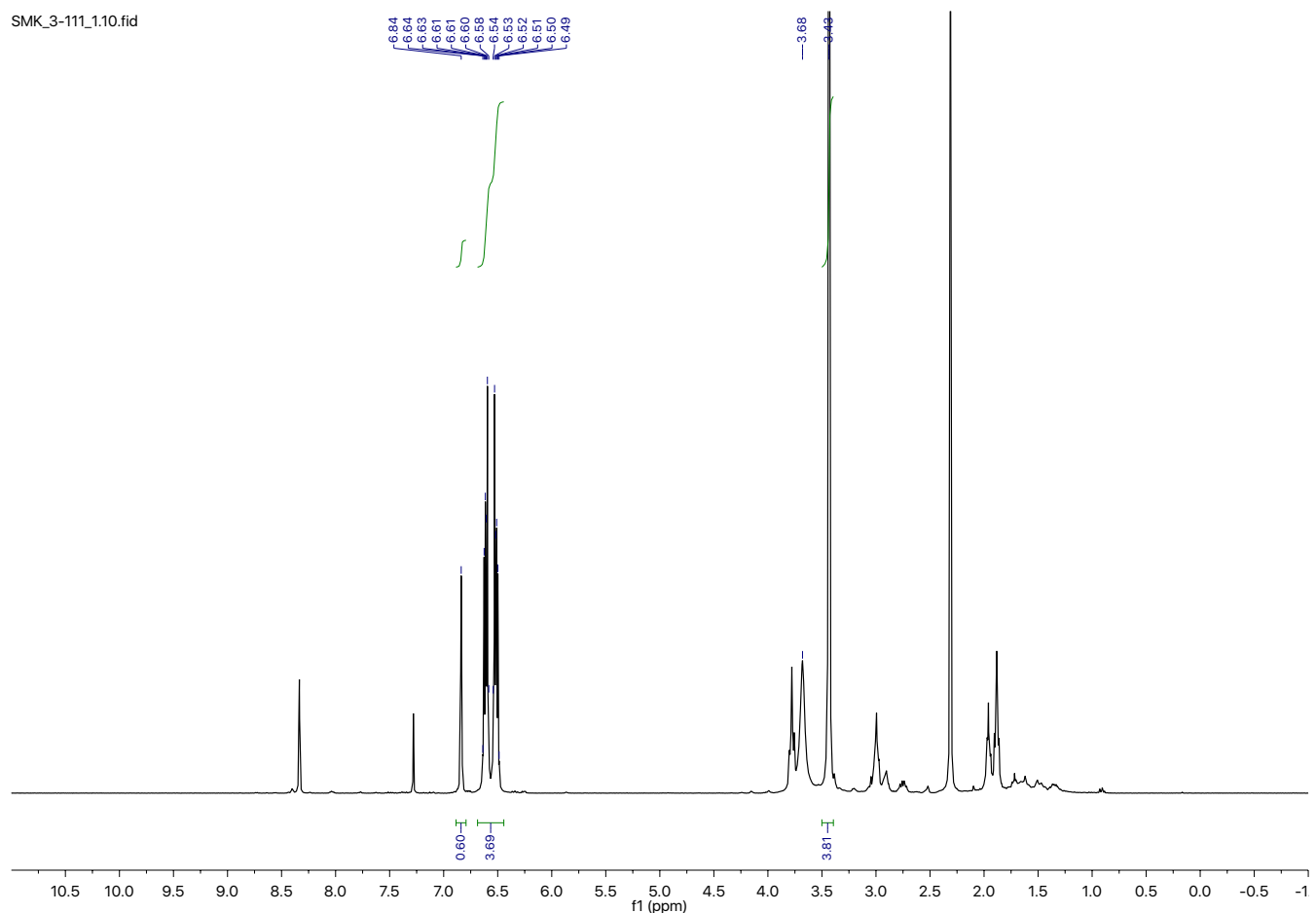

Figure S41. ${ }^{1} \mathrm{H}$ NMR spectrum of a crude product of $3 \mathrm{u}$ in $\mathrm{CDCl}_{3}$. Mesitylene was used as an internal standard. 


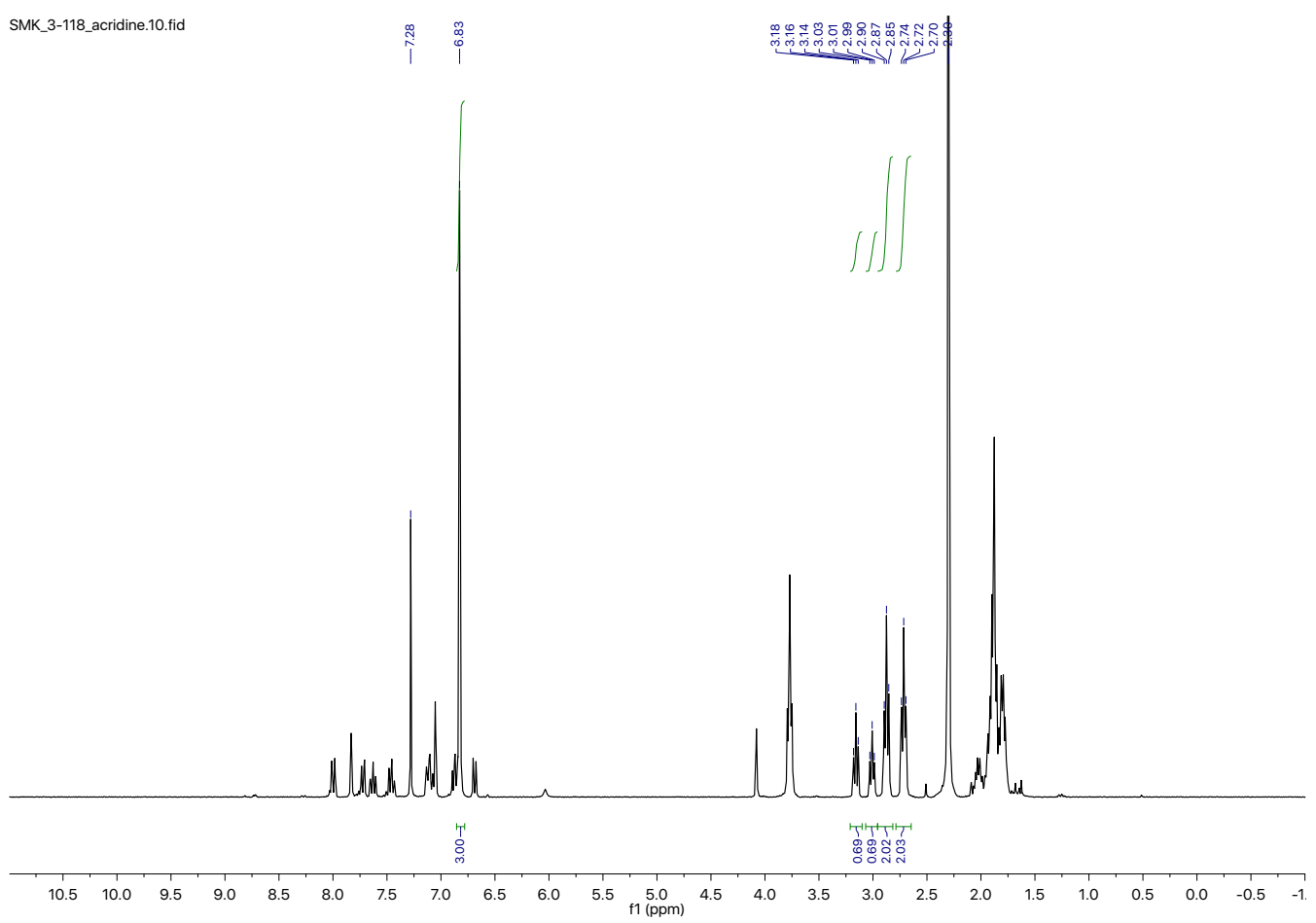

Figure S42. ${ }^{1} \mathrm{H}$ NMR spectrum of a crude mixture of $3 v$ and $3 w$ in $\mathrm{CDCl}_{3}$. Mesitylene was used as an internal standard.

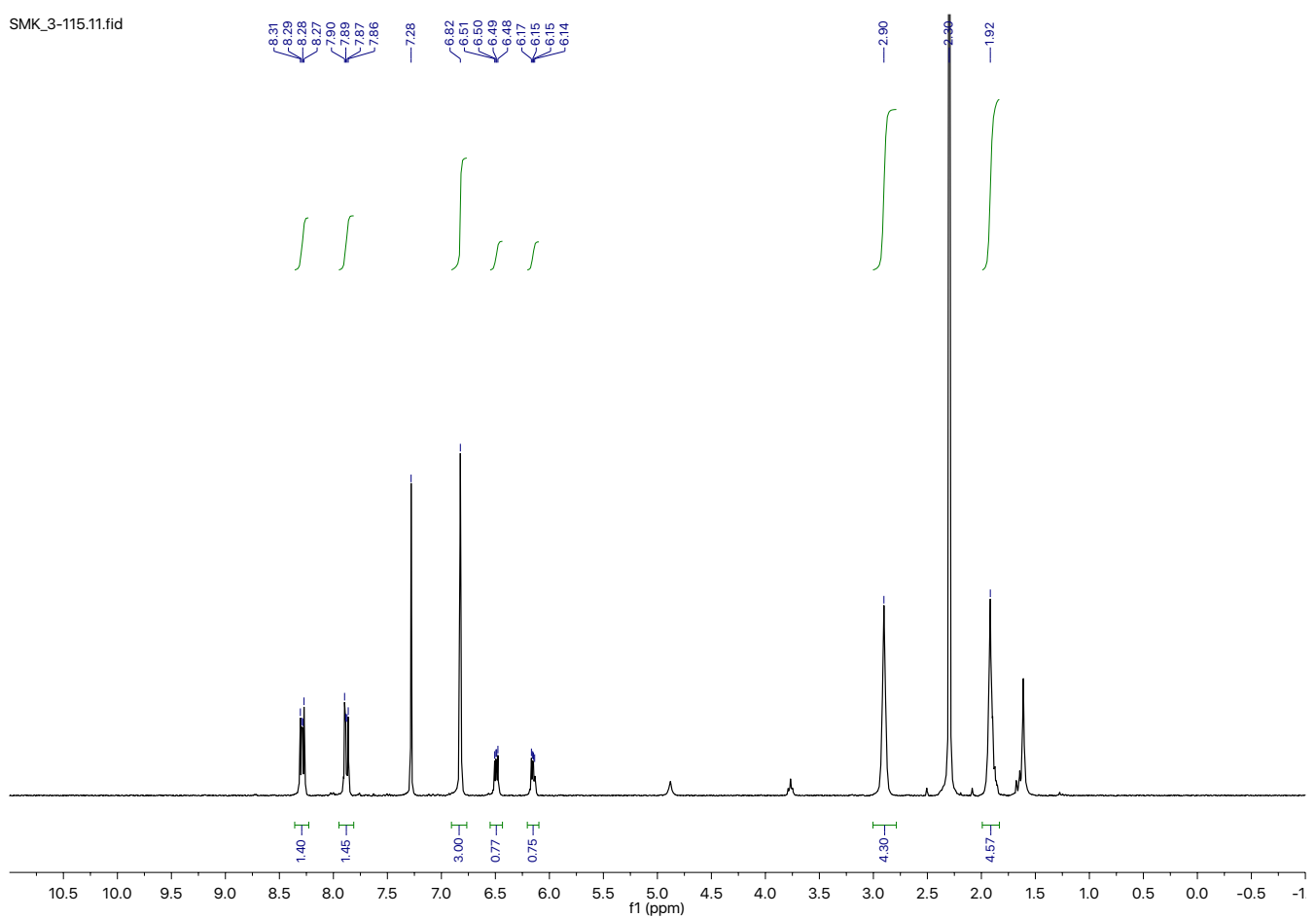

Figure S43. ${ }^{1} \mathrm{H}$ NMR spectrum of a crude mixture of $3 \mathrm{x}$ and $3 \mathrm{y}$ in $\mathrm{CDCl}_{3}$. Mesitylene was used as an internal standard. 


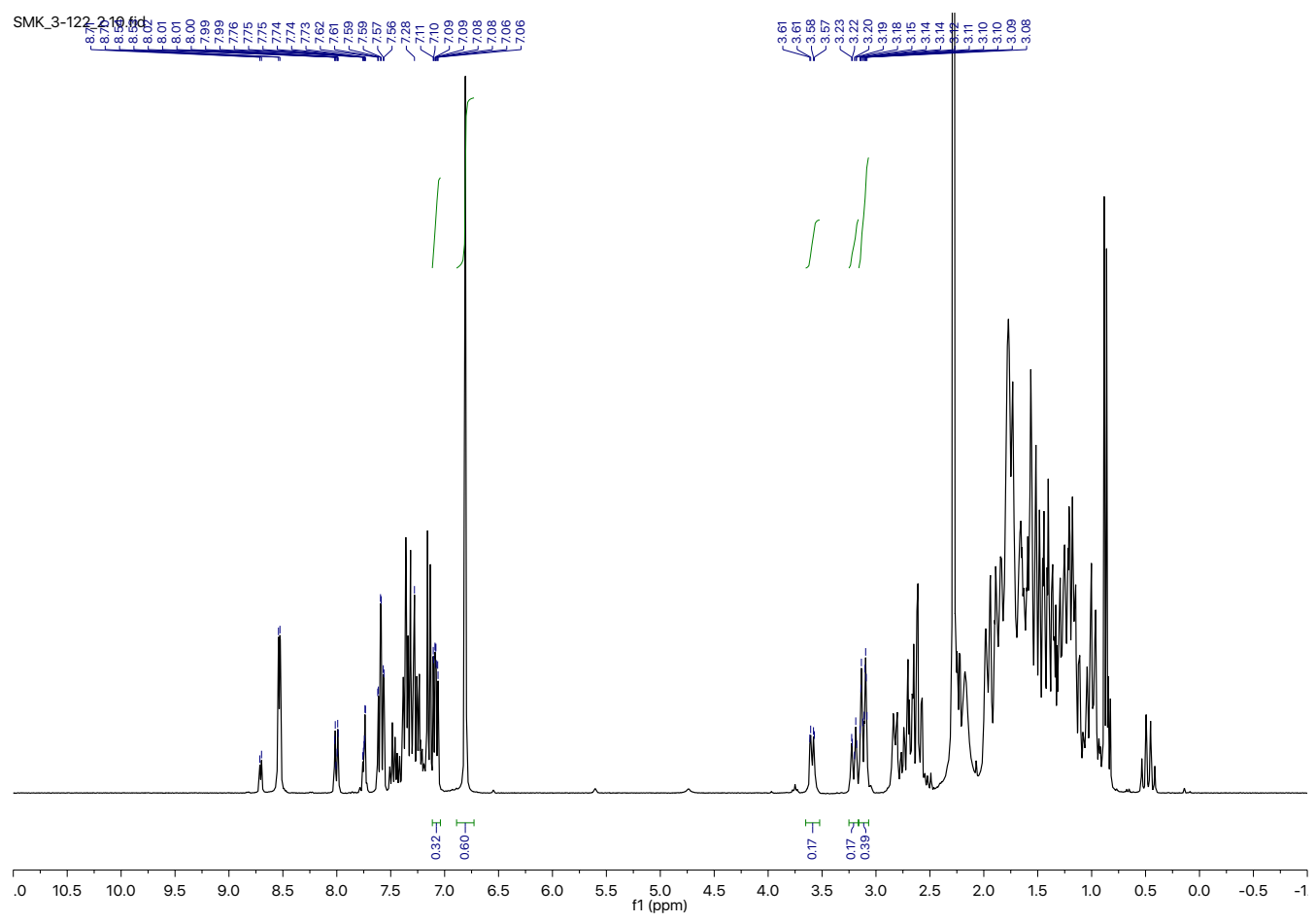

Figure S44. ${ }^{1} \mathrm{H}$ NMR spectrum of a crude mixture of $3 \mathrm{~m}, 3 \mathrm{n}$ and 30 in $\mathrm{CDCl}_{3}$. Mesitylene was used as an internal standard.

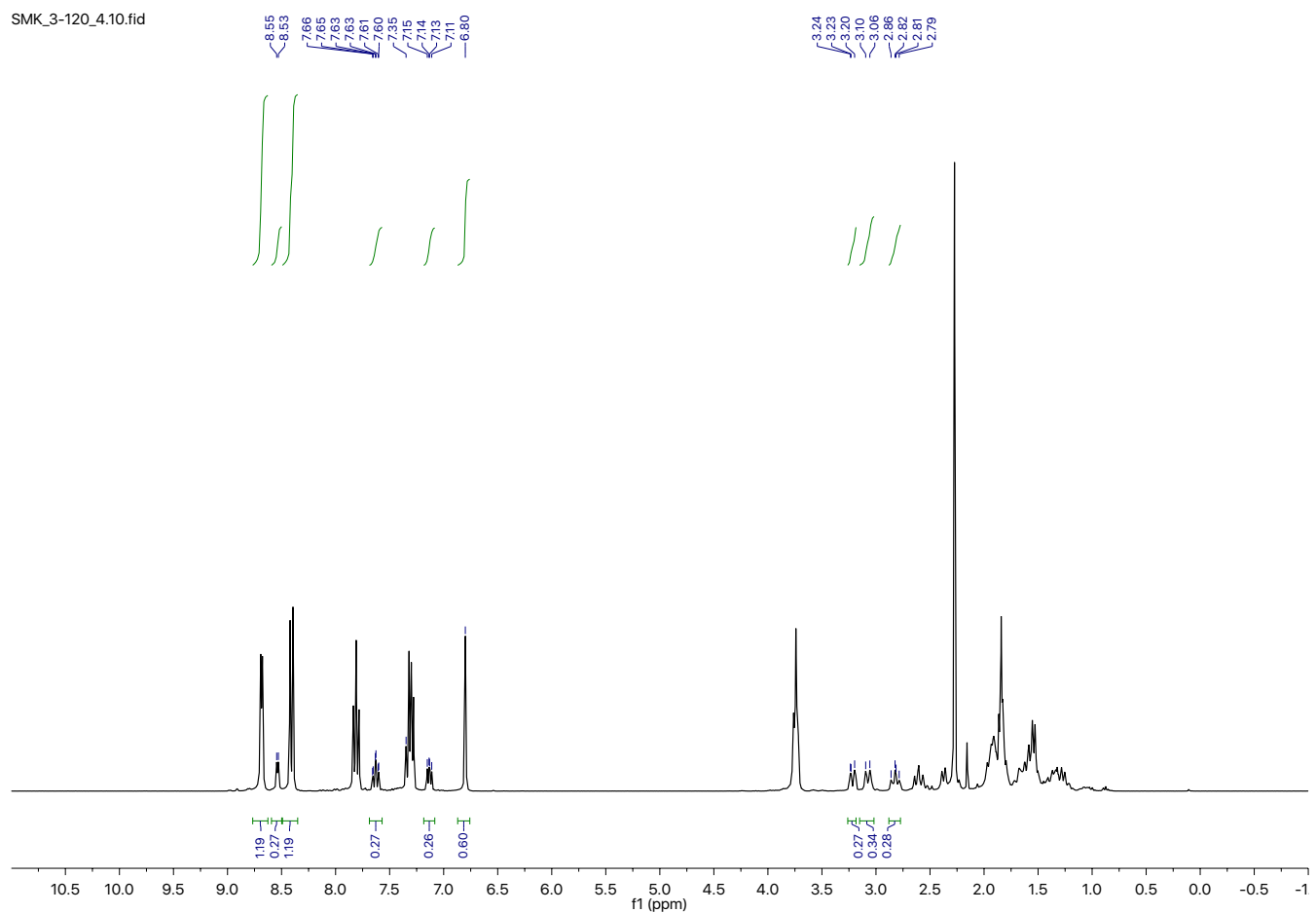

Figure S45. ${ }^{1} \mathrm{H}$ NMR spectrum of a crude mixture of $3 p$ and $3 q$ in $\mathrm{CDCl}_{3}$. Mesitylene was used as an internal standard. 


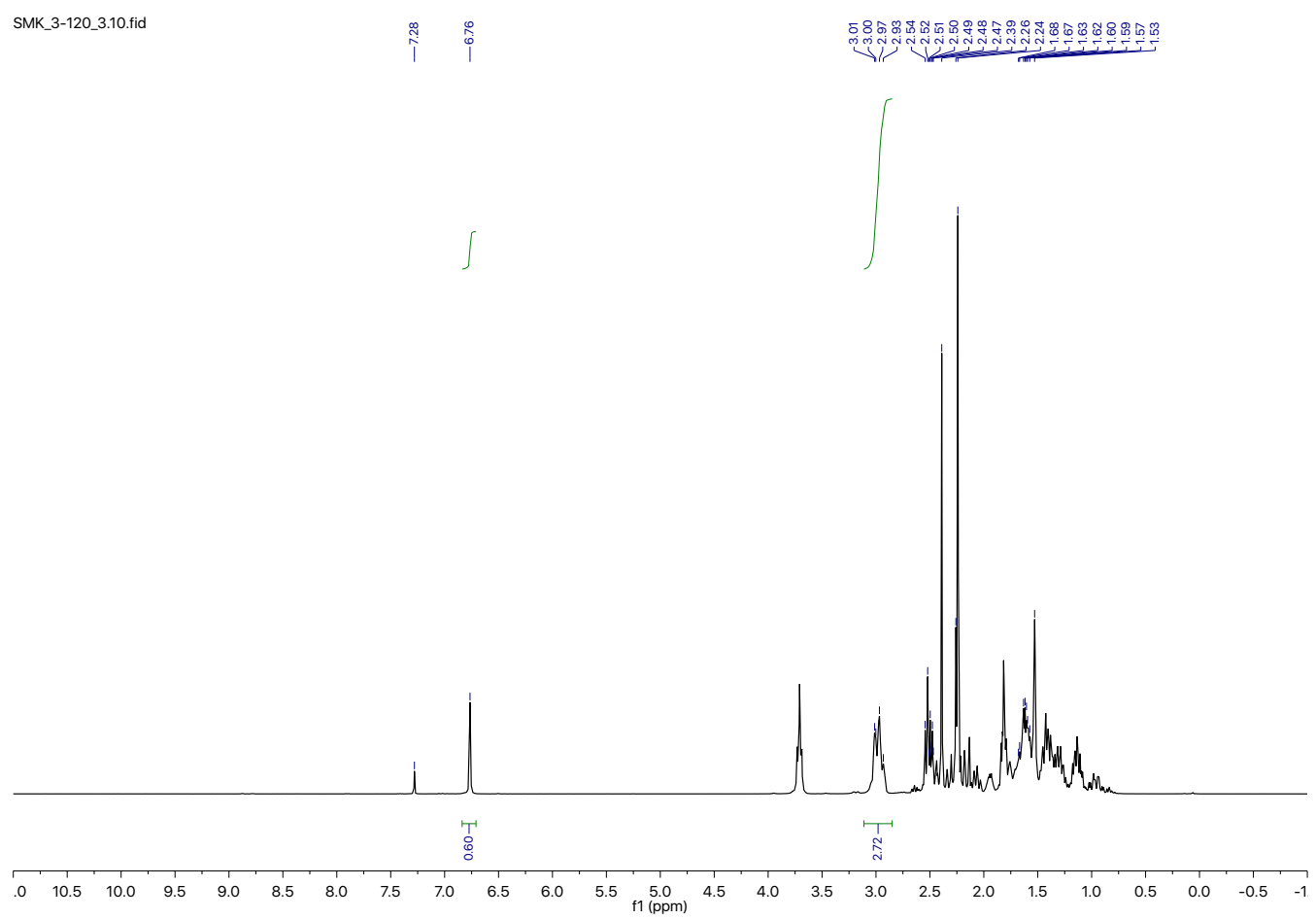

Figure S46. ${ }^{1} \mathrm{H}$ NMR spectrum of a crude product of $3 \mathrm{r}$ in $\mathrm{CDCl}_{3}$. Mesitylene was used as an internal standard.

SMK_3-120_3_qC_A2.10.fid
quant13Cp1.PU CDCl3/opt/topspin3.0 sangmink 98
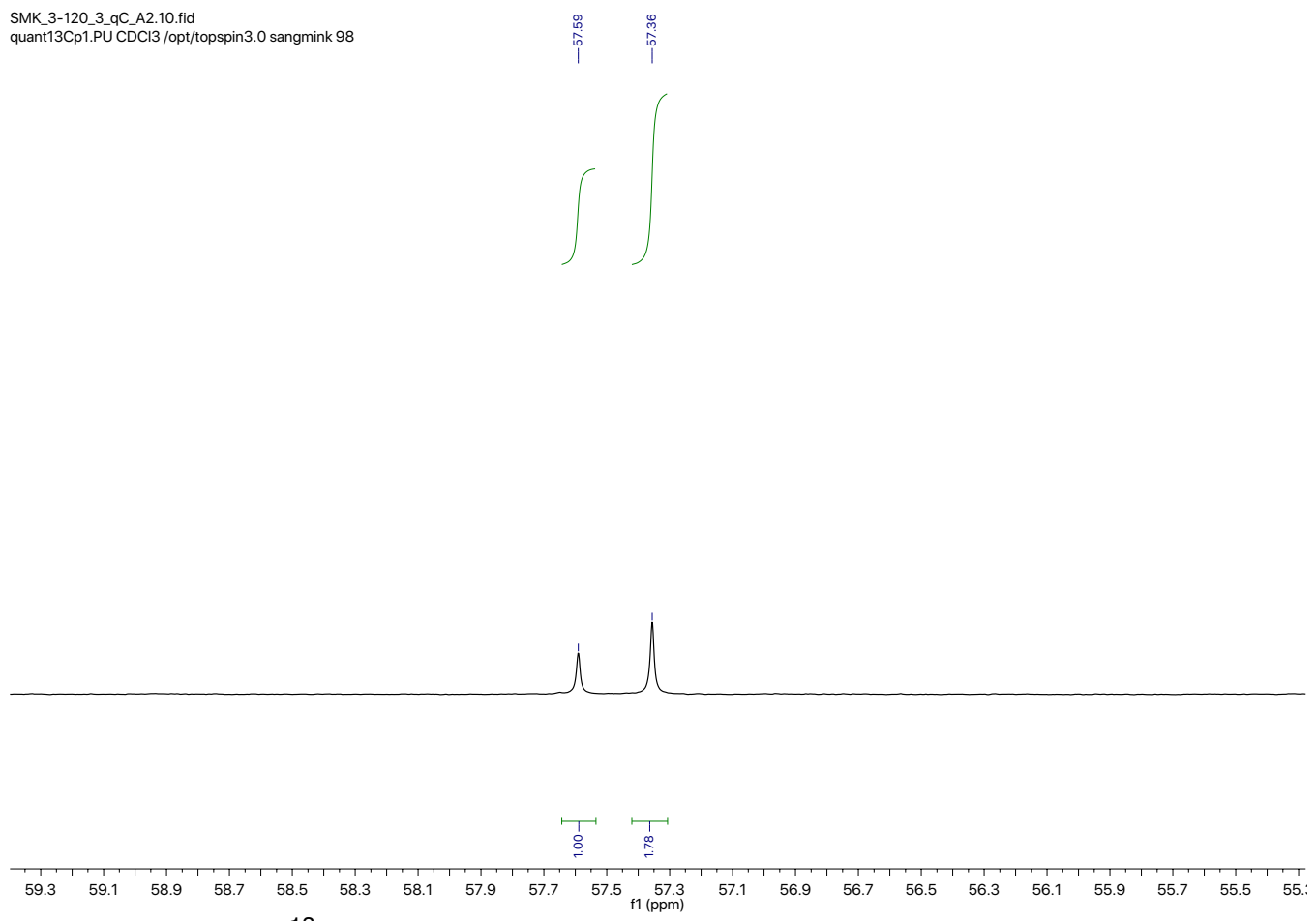

Figure S47. Quantitative ${ }^{13} \mathrm{C}$ NMR spectrum of a crude product of $3 \mathrm{r}$ in $\mathrm{CDCl}_{3}$. The peak at $57.6 \mathrm{ppm}$ is the signal of 2 'S,3R-hexahydronicotine and the peak at $57.4 \mathrm{ppm}$ is the signal of 2 'S,3S-hexahydronicotine. 


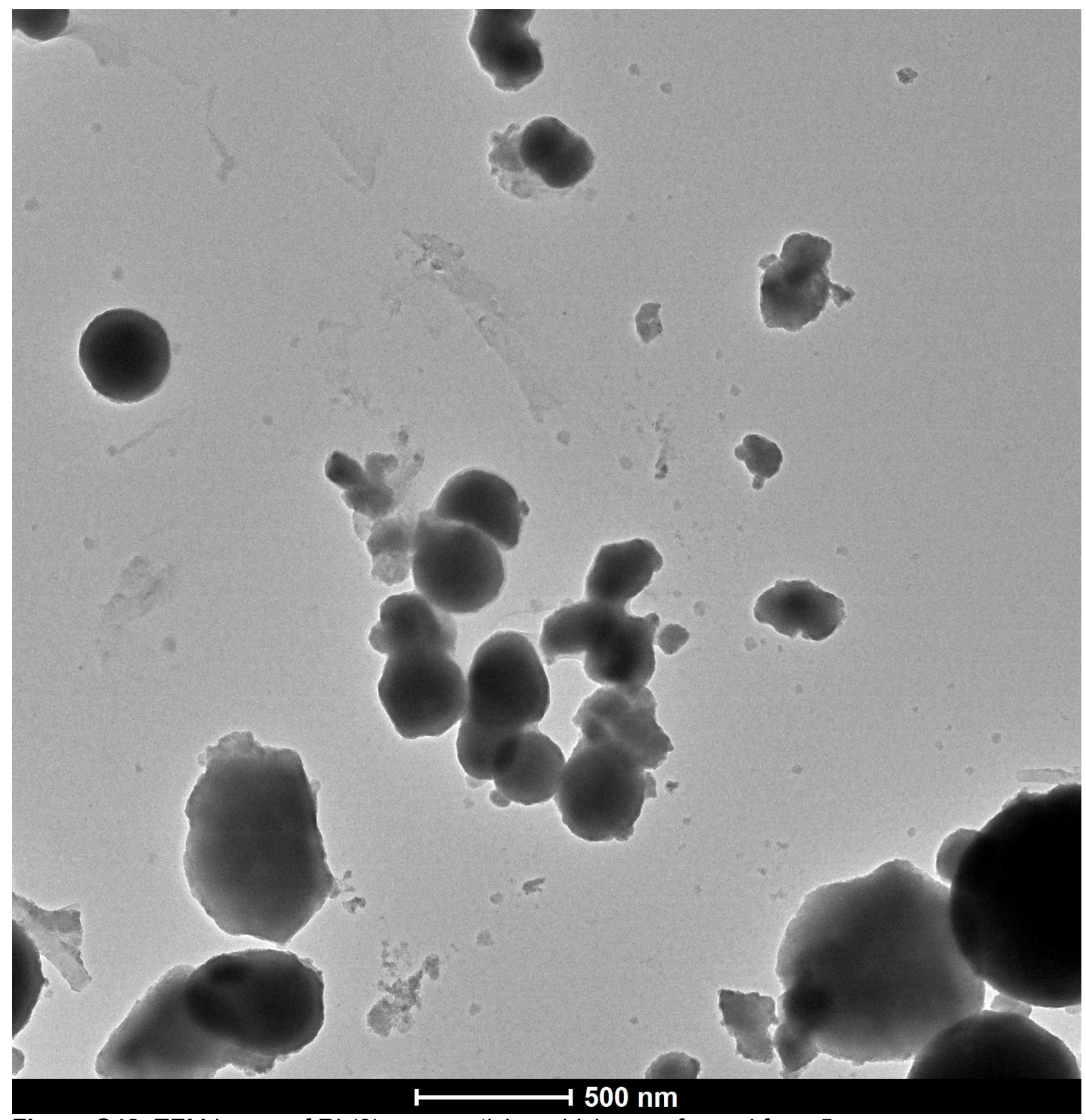

Figure S48. TEM image of $\mathrm{Rh}(0)$ nanoparticles which were formed from $\mathbf{5}$. 


\section{Crystallographic Data}

Compound 4

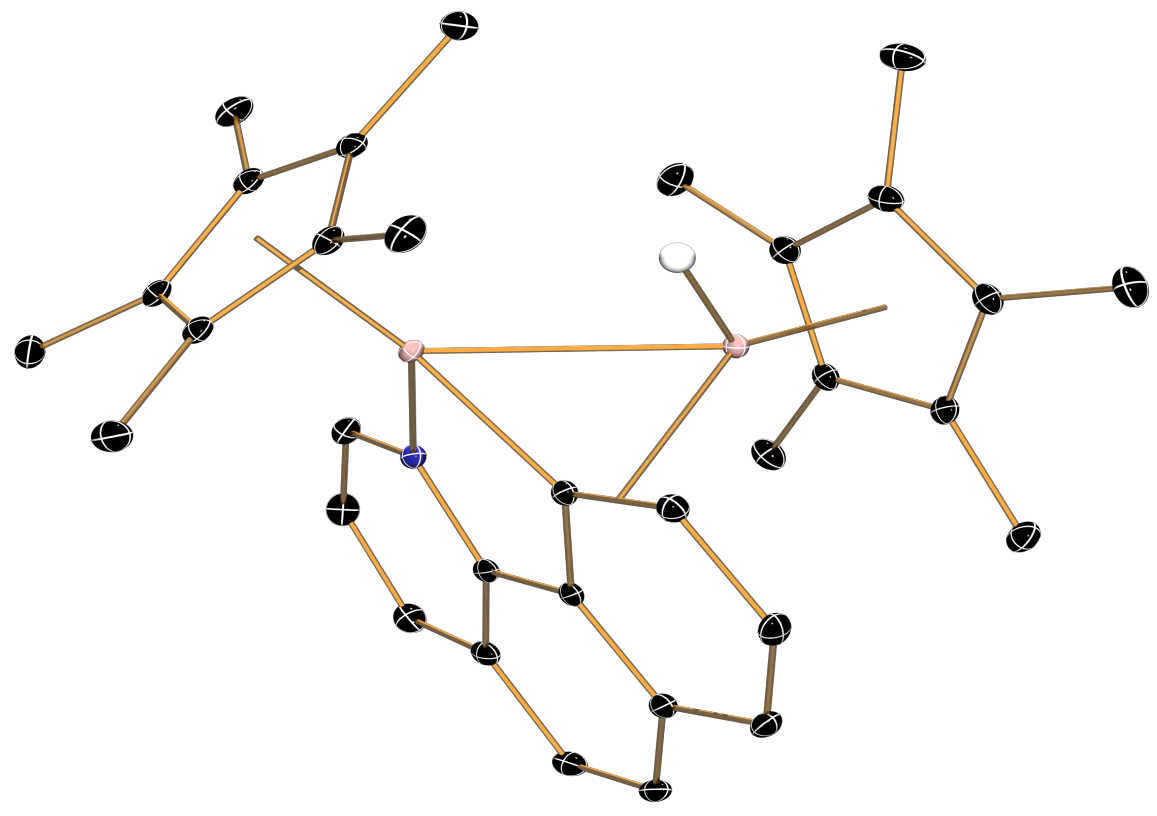

\section{Computing details}

Data collection: Bruker APEX3; cell refinement: Bruker SAINT; data reduction: Bruker SAINT; program(s) used to solve structure: SHELXT (Sheldrick 2016); program(s) used to refine structure: SHELXL97 (Sheldrick, 2008); molecular graphics: ORTEP-3 (Farraguia, 1994).

\section{References}

\section{NOT FOUND}

\section{(smk4)}

Crystal data

\begin{tabular}{|l|l|}
\hline $\mathrm{C}_{33} \mathrm{H}_{39} \mathrm{NRh}_{2}$ & $F(000)=1336$ \\
\hline$M_{r}=655.47$ & $D_{\mathrm{x}}=1.619 \mathrm{Mg} \mathrm{m}^{-3}$ \\
\hline Monoclinic, $P 2_{1} / c$ & Mo $K \alpha$ radiation, $\lambda=0.71073 \AA$ \\
\hline$a=11.4750(4) \AA$ & Cell parameters from 9700 reflections \\
\hline$b=13.8939(5) \AA$ & $\theta=2.6-29.6^{\circ}$ \\
\hline$c=16.9005(6) \AA$ & $\mu=1.25 \mathrm{~mm}^{-1}$ \\
\hline
\end{tabular}




\begin{tabular}{|l|l|}
\hline$\beta=93.671(1)^{\circ}$ & $T=100 \mathrm{~K}$ \\
\hline$V=2688.96(17) \AA^{3}$ & Block, black \\
\hline$Z=4$ & $0.15 \times 0.12 \times 0.11 \mathrm{~mm}$ \\
\hline
\end{tabular}

Data collection

\begin{tabular}{|l|l|}
\hline $\begin{array}{l}\text { Bruker D8 Venture Photon } 100 \text { CMOS } \\
\text { diffractometer }\end{array}$ & 6500 reflections with $I>2 \sigma(I)$ \\
\hline Radiation source: I $\mu$ S microfocus source & $R_{\text {int }}=0.037$ \\
\hline phi and $\omega$ scans & $\theta_{\max }=29.6^{\circ}, \theta_{\min }=1.9^{\circ}$ \\
\hline $\begin{array}{l}\text { Absorption correction: multi-scan } \\
\text { TWINABS BRUKER AXS }\end{array}$ & $h=-15 \rightarrow 15$ \\
\hline$T_{\min }=0.688, T_{\max }=0.746$ & $k=-19 \rightarrow 19$ \\
\hline 72327 measured reflections & $l=-23 \rightarrow 23$ \\
\hline 7546 independent reflections & \\
\hline
\end{tabular}

\section{Refinement}

\begin{tabular}{|l|l|}
\hline Refinement on $F^{2}$ & 0 restraints \\
\hline Least-squares matrix: full & Hydrogen site location: mixed \\
\hline$R\left[F^{2}>2 \sigma\left(F^{2}\right)\right]=0.028$ & $\begin{array}{l}\text { H atoms treated by a mixture of independent } \\
\text { and constrained refinement }\end{array}$ \\
\hline$w R\left(F^{2}\right)=0.056$ & $\begin{array}{l}w=1 /\left[\sigma^{2}\left(F_{\mathrm{o}}^{2}\right)+(0.0157 P)^{2}+4.1224 P\right] \\
\text { where } P=\left(F_{\mathrm{o}}{ }^{2}+2 F_{\mathrm{c}}{ }^{2}\right) / 3\end{array}$ \\
\hline$S=1.09$ & $(\Delta / \sigma)_{\max }=0.004$ \\
\hline 7546 reflections & $\Delta\rangle_{\max }=0.76 \mathrm{e} \AA^{-3}$ \\
\hline 346 parameters & $\Delta\rangle_{\min }=-0.47 \mathrm{e} \AA^{-3}$ \\
\hline
\end{tabular}

\section{Special details}

Experimental. Collected, solved and refined by Mate J. Bezdek.

Geometry. All esds (except the esd in the dihedral angle between two 1.s. planes) are estimated using the full covariance matrix. The cell esds are taken into account individually in the estimation of esds in distances, angles and torsion angles; correlations between esds in cell parameters are only used when they are defined by crystal symmetry. An approximate (isotropic) treatment of cell esds is used for estimating esds involving 1.s. planes.

Fractional atomic coordinates and isotropic or equivalent isotropic displacement parameters $\left(\AA^{2}\right)$ 


\begin{tabular}{|c|c|c|c|c|}
\hline & $x$ & $y$ & $z$ & $U_{\text {iso }} * / U_{\text {eq }}$ \\
\hline $\mathrm{C} 1$ & $0.28778(16)$ & $0.54775(14)$ & $0.78480(12)$ & $0.0110(4)$ \\
\hline $\mathrm{C} 2$ & $0.23965(17)$ & $0.47860(14)$ & $0.83398(13)$ & $0.0134(4)$ \\
\hline $\mathrm{C} 3$ & $0.24222(18)$ & $0.49852(16)$ & $0.91546(13)$ & $0.0163(4)$ \\
\hline $\mathrm{H} 3$ & $0.2125(9)$ & $0.4541(13)$ & $0.9506(10)$ & $0.020^{*}$ \\
\hline $\mathrm{C} 4$ & $0.28914(18)$ & $0.58444(16)$ & $0.94306(13)$ & $0.0169(4)$ \\
\hline H4 & $0.29080(19)$ & $0.5994(4)$ & $0.9986(15)$ & $0.020 *$ \\
\hline $\mathrm{C} 5$ & $0.33431(17)$ & $0.64978(15)$ & $0.89006(12)$ & $0.0138(4)$ \\
\hline H5 & $0.3642(8)$ & $0.7077(16)$ & $0.9099(6)$ & $0.017 *$ \\
\hline $\mathrm{C} 6$ & $0.28464(16)$ & $0.53699(14)$ & $0.70175(12)$ & $0.0109(4)$ \\
\hline C7 & $0.33632(16)$ & $0.61455(14)$ & $0.65863(12)$ & 0.0107 (4) \\
\hline $\mathrm{C} 8$ & $0.32085(17)$ & $0.60911(15)$ & $0.57454(12)$ & $0.0134(4)$ \\
\hline H8 & $0.3479(8)$ & $0.6574(14)$ & $0.5438(9)$ & $0.016^{*}$ \\
\hline C9 & $0.26218(18)$ & $0.52703(15)$ & $0.53813(13)$ & $0.0160(4)$ \\
\hline H9 & $0.2530(3)$ & $0.52403(18)$ & $0.4834(16)$ & $0.019 *$ \\
\hline $\mathrm{C} 10$ & $0.21972(18)$ & $0.45369(15)$ & $0.58149(13)$ & $0.0162(4)$ \\
\hline $\mathrm{H} 10$ & $0.1850(10)$ & $0.4019(15)$ & $0.5562(7)$ & $0.019^{*}$ \\
\hline C11 & $0.22902(17)$ & 0.45707 (14) & $0.66612(13)$ & $0.0133(4)$ \\
\hline $\mathrm{C} 12$ & $0.18239(17)$ & $0.38561(15)$ & $0.71628(13)$ & $0.0154(4)$ \\
\hline H12 & $0.1470(10)$ & $0.3302(15)$ & $0.6931(7)$ & $0.018^{*}$ \\
\hline $\mathrm{C} 13$ & $0.18770(17)$ & $0.39540(15)$ & $0.79652(13)$ & 0.0153 (4) \\
\hline H13 & $0.1579(9)$ & $0.3485(14)$ & $0.8267(9)$ & $0.018^{*}$ \\
\hline C14 & $0.54613(17)$ & $0.78847(14)$ & $0.66315(12)$ & $0.0123(4)$ \\
\hline C15 & $0.49225(17)$ & $0.86061(14)$ & $0.71075(12)$ & $0.0126(4)$ \\
\hline $\mathrm{C} 16$ & $0.51363(17)$ & $0.83553(14)$ & $0.79152(12)$ & $0.0125(4)$ \\
\hline C17 & $0.58334(17)$ & $0.74885(15)$ & $0.79493(12)$ & $0.0125(4)$ \\
\hline C18 & 0.60677 (17) & $0.72205(14)$ & $0.71610(12)$ & $0.0124(4)$ \\
\hline C19 & $0.55674(19)$ & $0.79168(16)$ & $0.57549(13)$ & $0.0178(4)$ \\
\hline H19A & 0.4903 & 0.8243 & 0.5507 & $0.027 *$ \\
\hline H19B & 0.5601 & 0.7273 & 0.5552 & $0.027 *$ \\
\hline H19C & 0.6267 & 0.8255 & 0.5642 & $0.027 *$ \\
\hline $\mathrm{C} 20$ & $0.43220(19)$ & $0.95013(15)$ & $0.68098(14)$ & $0.0188(4)$ \\
\hline $\mathrm{H} 20 \mathrm{~A}$ & 0.4286 & 0.9507 & 0.6241 & $0.028 *$ \\
\hline H20B & 0.4750 & 1.0054 & 0.7009 & $0.028^{*}$ \\
\hline $\mathrm{H} 20 \mathrm{C}$ & 0.3545 & 0.9519 & 0.6989 & $0.028 *$ \\
\hline $\mathrm{C} 21$ & $0.47599(19)$ & $0.89291(16)$ & $0.86088(13)$ & $0.0175(4)$ \\
\hline $\mathrm{H} 21 \mathrm{~A}$ & 0.4963 & 0.8587 & 0.9091 & $0.026^{*}$ \\
\hline
\end{tabular}




\begin{tabular}{|c|c|c|c|c|}
\hline $\mathrm{H} 21 \mathrm{~B}$ & 0.3930 & 0.9025 & 0.8556 & $0.026^{*}$ \\
\hline $\mathrm{H} 21 \mathrm{C}$ & 0.5147 & 0.9542 & 0.8622 & $0.026^{*}$ \\
\hline $\mathrm{C} 22$ & $0.63316(19)$ & $0.70207(16)$ & $0.86948(13)$ & $0.0180(4)$ \\
\hline $\mathrm{H} 22 \mathrm{~A}$ & 0.5709 & 0.6848 & 0.9021 & $0.027 *$ \\
\hline $\mathrm{H} 22 \mathrm{~B}$ & 0.6850 & 0.7462 & 0.8978 & $0.027^{*}$ \\
\hline $\mathrm{H} 22 \mathrm{C}$ & 0.6755 & 0.6453 & 0.8563 & $0.027 *$ \\
\hline $\mathrm{C} 23$ & $0.68865(18)$ & $0.64518(15)$ & $0.69153(14)$ & $0.0177(4)$ \\
\hline $\mathrm{H} 23 \mathrm{~A}$ & 0.6565 & 0.6145 & 0.6441 & $0.027 *$ \\
\hline H23B & 0.6992 & 0.5983 & 0.7331 & $0.027 *$ \\
\hline $\mathrm{H} 23 \mathrm{C}$ & 0.7626 & 0.6735 & 0.6817 & $0.027^{*}$ \\
\hline $\mathrm{C} 24$ & $0.08545(17)$ & $0.84342(15)$ & $0.63094(13)$ & $0.0141(4)$ \\
\hline $\mathrm{C} 25$ & $0.04063(17)$ & $0.76986(15)$ & $0.57831(13)$ & $0.0139(4)$ \\
\hline $\mathrm{C} 26$ & $0.02228(17)$ & $0.68567(15)$ & $0.62565(13)$ & $0.0132(4)$ \\
\hline $\mathrm{C} 27$ & $0.05251(17)$ & $0.70759(15)$ & $0.70665(12)$ & $0.0124(4)$ \\
\hline $\mathrm{C} 28$ & $0.09596(17)$ & $0.80430(15)$ & $0.71008(13)$ & $0.0137(4)$ \\
\hline $\mathrm{C} 29$ & $0.10050(19)$ & $0.94755(15)$ & $0.60989(15)$ & $0.0205(5)$ \\
\hline $\mathrm{H} 29 \mathrm{~A}$ & 0.1618 & 0.9751 & 0.6440 & $0.031 *$ \\
\hline $\mathrm{H} 29 \mathrm{~B}$ & 0.0289 & 0.9815 & 0.6165 & $0.031^{*}$ \\
\hline $\mathrm{H} 29 \mathrm{C}$ & 0.1204 & 0.9526 & 0.5557 & $0.031 *$ \\
\hline $\mathrm{C} 30$ & $0.0062(2)$ & $0.78072(18)$ & $0.49192(14)$ & $0.0220(5)$ \\
\hline $\mathrm{H} 30 \mathrm{~A}$ & 0.0217 & 0.7218 & 0.4649 & $0.033^{*}$ \\
\hline H30B & 0.0504 & 0.8320 & 0.4703 & $0.033^{*}$ \\
\hline $\mathrm{H} 30 \mathrm{C}$ & -0.0756 & 0.7954 & 0.4851 & $0.033^{*}$ \\
\hline C31 & $-0.02678(18)$ & $0.59209(16)$ & $0.59472(14)$ & $0.0177(4)$ \\
\hline H31A & -0.0036 & 0.5819 & 0.5418 & $0.027^{*}$ \\
\hline H31B & -0.1105 & 0.5939 & 0.5943 & $0.027^{*}$ \\
\hline $\mathrm{H} 31 \mathrm{C}$ & 0.0022 & 0.5405 & 0.6283 & $0.027 *$ \\
\hline C32 & $0.03274(18)$ & $0.64395(16)$ & $0.77557(13)$ & $0.0170(4)$ \\
\hline $\mathrm{H} 32 \mathrm{~A}$ & 0.0894 & 0.6583 & 0.8182 & $0.025^{*}$ \\
\hline H32B & 0.0405 & 0.5779 & 0.7601 & $0.025^{*}$ \\
\hline $\mathrm{H} 32 \mathrm{C}$ & -0.0444 & 0.6547 & 0.7927 & $0.025^{*}$ \\
\hline C33 & $0.13203(19)$ & $0.85883(17)$ & $0.78413(13)$ & $0.0196(5)$ \\
\hline H33A & 0.1857 & 0.9089 & 0.7719 & $0.029 *$ \\
\hline H33B & 0.1691 & 0.8157 & 0.8223 & $0.029^{*}$ \\
\hline $\mathrm{H} 33 \mathrm{C}$ & 0.0644 & 0.8868 & 0.8056 & $0.029 *$ \\
\hline N1 & $0.33656(14)$ & $0.63307(12)$ & $0.81248(10)$ & $0.0110(3)$ \\
\hline Rh1 & $0.41603(2)$ & $0.71381(2)$ & $0.72824(2)$ & $0.00874(4)$ \\
\hline
\end{tabular}




\begin{tabular}{|l|l|l|l|l|}
\hline Rh2 & $0.21429(2)$ & $0.72699(2)$ & $0.63403(2)$ & $0.00959(4)$ \\
\hline H2A & $0.306(2)$ & $0.7879(16)$ & $0.5993(14)$ & $0.012^{*}$ \\
\hline
\end{tabular}

Atomic displacement parameters $\left(\AA^{2}\right)$

\begin{tabular}{|c|c|c|c|c|c|c|}
\hline & $U^{11}$ & $U^{22}$ & $U^{33}$ & $U^{12}$ & $U^{13}$ & $U^{23}$ \\
\hline $\mathrm{C} 1$ & $0.0062(9)$ & $0.0108(9)$ & $0.0161(10)$ & $0.0018(7)$ & $0.0017(7)$ & $-0.0006(7)$ \\
\hline $\mathrm{C} 2$ & $0.0083(9)$ & $0.0121(9)$ & $0.0200(11)$ & $0.0019(7)$ & $0.0022(8)$ & $0.0013(8)$ \\
\hline $\mathrm{C} 3$ & $0.0131(10)$ & $0.0184(10)$ & $0.0178(11)$ & $-0.0002(8)$ & $0.0041(8)$ & $0.0046(9)$ \\
\hline $\mathrm{C} 4$ & $0.0152(10)$ & $0.0232(11)$ & $0.0127(10)$ & $-0.0002(8)$ & $0.0031(8)$ & $0.0002(8)$ \\
\hline $\mathrm{C} 5$ & $0.0118(9)$ & $0.0159(10)$ & $0.0138(10)$ & $-0.0016(8)$ & $0.0006(7)$ & $-0.0030(8)$ \\
\hline C6 & $0.0072(9)$ & $0.0107(9)$ & $0.0148(10)$ & $0.0024(7)$ & $-0.0003(7)$ & $-0.0003(7)$ \\
\hline C7 & $0.0076(9)$ & $0.0114(9)$ & $0.0130(10)$ & $0.0012(7)$ & $0.0006(7)$ & $-0.0008(7)$ \\
\hline $\mathrm{C} 8$ & $0.0130(10)$ & $0.0134(9)$ & $0.0137(10)$ & $0.0020(7)$ & $0.0001(7)$ & $-0.0008(8)$ \\
\hline C9 & $0.0162(10)$ & $0.0191(10)$ & $0.0124(11)$ & $0.0023(8)$ & $-0.0020(8)$ & $-0.0059(8)$ \\
\hline C10 & $0.0131(10)$ & $0.0136(10)$ & $0.0213(11)$ & $0.0001(8)$ & $-0.0033(8)$ & $-0.0068(8)$ \\
\hline C11 & $0.0093(9)$ & $0.0116(9)$ & $0.0188(11)$ & $0.0019(7)$ & $-0.0010(7)$ & $-0.0019(8)$ \\
\hline $\mathrm{C} 12$ & $0.0087(9)$ & $0.0102(9)$ & $0.0273(12)$ & $-0.0001(7)$ & $0.0009(8)$ & $-0.0033(8)$ \\
\hline C13 & $0.0096(9)$ & $0.0114(9)$ & $0.0254(12)$ & $-0.0004(7)$ & $0.0057(8)$ & $0.0028(8)$ \\
\hline C14 & $0.0095(9)$ & $0.0144(9)$ & $0.0132(10)$ & $-0.0038(7)$ & $0.0019(7)$ & $-0.0003(8)$ \\
\hline C15 & $0.0098(9)$ & $0.0113(9)$ & $0.0168(10)$ & $-0.0031(7)$ & $0.0010(7)$ & $-0.0007(8)$ \\
\hline C16 & $0.0092(9)$ & $0.0131(9)$ & $0.0154(10)$ & $-0.0032(7)$ & $0.0017(7)$ & $-0.0023(8)$ \\
\hline C17 & $0.0089(9)$ & $0.0138(9)$ & $0.0149(10)$ & $-0.0042(7)$ & $0.0008(7)$ & $-0.0012(8)$ \\
\hline C18 & $0.0088(9)$ & $0.0131(9)$ & $0.0152(10)$ & $-0.0035(7)$ & $0.0011(7)$ & $-0.0013(8)$ \\
\hline C19 & $0.0167(10)$ & $0.0227(11)$ & $0.0142(11)$ & $-0.0055(8)$ & $0.0033(8)$ & $-0.0009(9)$ \\
\hline $\mathrm{C} 20$ & $0.0169(10)$ & $0.0141(10)$ & $0.0250(12)$ & $-0.0001(8)$ & $-0.0005(9)$ & $0.0014(9)$ \\
\hline C21 & $0.0168(10)$ & $0.0181(10)$ & $0.0180(11)$ & $-0.0047(8)$ & $0.0030(8)$ & $-0.0067(9)$ \\
\hline $\mathrm{C} 22$ & $0.0138(10)$ & $0.0210(11)$ & $0.0186(11)$ & $-0.0018(8)$ & $-0.0034(8)$ & $0.0018(9)$ \\
\hline $\mathrm{C} 23$ & $0.0141(10)$ & $0.0160(10)$ & $0.0236(12)$ & $-0.0001(8)$ & $0.0054(8)$ & $-0.0021(9)$ \\
\hline C24 & $0.0104(9)$ & $0.0132(9)$ & $0.0192(11)$ & $0.0025(7)$ & $0.0046(8)$ & $0.0010(8)$ \\
\hline C25 & $0.0085(9)$ & $0.0176(10)$ & $0.0158(10)$ & $0.0029(7)$ & $0.0022(7)$ & $0.0018(8)$ \\
\hline $\mathrm{C} 26$ & $0.0066(9)$ & $0.0156(9)$ & $0.0175(10)$ & $0.0000(7)$ & $0.0009(7)$ & $-0.0007(8)$ \\
\hline C27 & $0.0078(9)$ & $0.0151(10)$ & $0.0143(10)$ & $0.0021(7)$ & $0.0016(7)$ & $0.0013(8)$ \\
\hline $\mathrm{C} 28$ & $0.0094(9)$ & $0.0152(10)$ & $0.0169(10)$ & $0.0024(7)$ & $0.0027(7)$ & $-0.0017(8)$ \\
\hline C29 & $0.0174(11)$ & $0.0139(10)$ & $0.0308(13)$ & $0.0024(8)$ & $0.0067(9)$ & $0.0027(9)$ \\
\hline C30 & $0.0187(11)$ & $0.0290(12)$ & $0.0180(11)$ & $0.0023(9)$ & $-0.0010(8)$ & $0.0055(9)$ \\
\hline C31 & $0.0124(10)$ & $0.0189(10)$ & $0.0217(12)$ & $-0.0022(8)$ & $-0.0005(8)$ & $-0.0043(9)$ \\
\hline
\end{tabular}




\begin{tabular}{|l|l|l|l|l|l|l|}
\hline C32 & $0.0131(10)$ & $0.0200(11)$ & $0.0183(11)$ & $0.0033(8)$ & $0.0044(8)$ & $0.0039(9)$ \\
\hline C33 & $0.0166(11)$ & $0.0225(11)$ & $0.0197(12)$ & $0.0003(8)$ & $0.0020(8)$ & $-0.0086(9)$ \\
\hline N1 & $0.0081(8)$ & $0.0113(8)$ & $0.0135(8)$ & $0.0001(6)$ & $0.0003(6)$ & $-0.0008(6)$ \\
\hline Rh1 & $0.00723(7)$ & $0.00945(7)$ & $0.00959(8)$ & $-0.00127(5)$ & $0.00091(5)$ & $-0.00094(5)$ \\
\hline Rh2 & $0.00805(7)$ & $0.01018(7)$ & $0.01057(8)$ & $0.00030(5)$ & $0.00077(5)$ & $0.00003(6)$ \\
\hline
\end{tabular}

Geometric parameters $\left(\AA,{ }^{\circ}\right)$

\begin{tabular}{|l|l|l|l|}
\hline $\mathrm{C} 1-\mathrm{N} 1$ & $1.380(3)$ & $\mathrm{C} 20-\mathrm{H} 20 \mathrm{~A}$ & 0.9600 \\
\hline $\mathrm{C} 1-\mathrm{C} 2$ & $1.406(3)$ & $\mathrm{C} 20-\mathrm{H} 20 \mathrm{~B}$ & 0.9600 \\
\hline $\mathrm{C} 1-\mathrm{C} 6$ & $1.410(3)$ & $\mathrm{C} 20-\mathrm{H} 20 \mathrm{C}$ & 0.9600 \\
\hline $\mathrm{C} 2-\mathrm{C} 3$ & $1.403(3)$ & $\mathrm{C} 21-\mathrm{H} 21 \mathrm{~A}$ & 0.9600 \\
\hline $\mathrm{C} 2-\mathrm{C} 13$ & $1.430(3)$ & $\mathrm{C} 21-\mathrm{H} 21 \mathrm{~B}$ & 0.9600 \\
\hline $\mathrm{C} 3-\mathrm{C} 4$ & $1.379(3)$ & $\mathrm{C} 21-\mathrm{H} 21 \mathrm{C}$ & 0.9600 \\
\hline $\mathrm{C} 3-\mathrm{H} 3$ & $0.93(3)$ & $\mathrm{C} 22-\mathrm{H} 22 \mathrm{~A}$ & 0.9600 \\
\hline $\mathrm{C} 4-\mathrm{C} 5$ & $1.398(3)$ & $\mathrm{C} 22-\mathrm{H} 22 \mathrm{~B}$ & 0.9600 \\
\hline $\mathrm{C} 4-\mathrm{H} 4$ & $0.96(3)$ & $\mathrm{C} 22-\mathrm{H} 22 \mathrm{C}$ & 0.9600 \\
\hline $\mathrm{C} 5-\mathrm{N} 1$ & $1.333(3)$ & $\mathrm{C} 23-\mathrm{H} 23 \mathrm{~A}$ & 0.9600 \\
\hline $\mathrm{C} 5-\mathrm{H} 5$ & $0.93(3)$ & $\mathrm{C} 23-\mathrm{H} 23 \mathrm{~B}$ & 0.9600 \\
\hline $\mathrm{C} 6-\mathrm{C} 11$ & $1.398(3)$ & $\mathrm{C} 23-\mathrm{H} 23 \mathrm{C}$ & 0.9600 \\
\hline $\mathrm{C} 6-\mathrm{C} 7$ & $1.449(3)$ & $\mathrm{C} 24-\mathrm{C} 25$ & $1.429(3)$ \\
\hline $\mathrm{C} 7-\mathrm{C} 8$ & $1.423(3)$ & $\mathrm{C} 24-\mathrm{C} 28$ & $1.442(3)$ \\
\hline $\mathrm{C} 7-\mathrm{Rh} 1$ & $1.9962(19)$ & $\mathrm{C} 24-\mathrm{C} 29$ & $1.503(3)$ \\
\hline $\mathrm{C} 7-\mathrm{Rh} 2$ & $2.1213(19)$ & $\mathrm{C} 24-\mathrm{Rh} 2$ & $2.190(2)$ \\
\hline $\mathrm{C} 8-\mathrm{C} 9$ & $1.442(3)$ & $\mathrm{C} 25-\mathrm{C} 26$ & $1.440(3)$ \\
\hline $\mathrm{C} 8-\mathrm{Rh} 2$ & $2.312(2)$ & $\mathrm{C} 25-\mathrm{C} 30$ & $1.495(3)$ \\
\hline $\mathrm{C} 8-\mathrm{H} 8$ & $0.91(3)$ & $\mathrm{C} 25-\mathrm{Rh} 2$ & $2.230(2)$ \\
\hline $\mathrm{C} 9-\mathrm{C} 10$ & $1.363(3)$ & $\mathrm{C} 26-\mathrm{C} 27$ & $1.423(3)$ \\
\hline $\mathrm{C} 9-\mathrm{H} 9$ & $0.93(3)$ & $\mathrm{C} 26-\mathrm{C} 31$ & $1.498(3)$ \\
\hline $\mathrm{C} 10-\mathrm{C} 11$ & $1.428(3)$ & $\mathrm{C} 26-\mathrm{Rh} 2$ & $2.2725(19)$ \\
\hline $\mathrm{C} 10-\mathrm{H} 10$ & $0.92(3)$ & $\mathrm{C} 27-\mathrm{C} 28$ & $1.433(3)$ \\
\hline $\mathrm{C} 11-\mathrm{C} 12$ & $1.431(3)$ & $\mathrm{C} 28-\mathrm{R} 2-\mathrm{H} 29 \mathrm{~B}$ & 0.9600 \\
\hline $\mathrm{C} 12-\mathrm{C} 13$ & $1.361(3)$ & $1.491(3)$ \\
\hline $\mathrm{C} 12-\mathrm{H} 12$ & $0.94(3)$ & $2.306(2)$ \\
\hline $\mathrm{C} 13-\mathrm{H} 13$ & $0.91(3)$ & $1.498(3)$ \\
\hline $\mathrm{C} 14-\mathrm{C} 18$ & $1.434(3)$ & $2.207(2)$ \\
\hline $\mathrm{C} 14-\mathrm{C} 15$ & $1.448(3)$ & 0.9600 \\
\hline
\end{tabular}




\begin{tabular}{|c|c|c|c|}
\hline $\mathrm{C} 14-\mathrm{C} 19$ & $1.495(3)$ & $\mathrm{C} 29-\mathrm{H} 29 \mathrm{C}$ & 0.9600 \\
\hline C14-Rh1 & $2.1738(19)$ & $\mathrm{C} 30-\mathrm{H} 30 \mathrm{~A}$ & 0.9600 \\
\hline $\mathrm{C} 15-\mathrm{C} 16$ & $1.415(3)$ & $\mathrm{C} 30-\mathrm{H} 30 \mathrm{~B}$ & 0.9600 \\
\hline $\mathrm{C} 15-\mathrm{C} 20$ & $1.493(3)$ & $\mathrm{C} 30-\mathrm{H} 30 \mathrm{C}$ & 0.9600 \\
\hline C15-Rh1 & $2.246(2)$ & $\mathrm{C} 31-\mathrm{H} 31 \mathrm{~A}$ & 0.9600 \\
\hline $\mathrm{C} 16-\mathrm{C} 17$ & $1.445(3)$ & C31-H31B & 0.9600 \\
\hline $\mathrm{C} 16-\mathrm{C} 21$ & $1.504(3)$ & $\mathrm{C} 31-\mathrm{H} 31 \mathrm{C}$ & 0.9600 \\
\hline C16-Rh1 & $2.259(2)$ & $\mathrm{C} 32-\mathrm{H} 32 \mathrm{~A}$ & 0.9600 \\
\hline $\mathrm{C} 17-\mathrm{C} 18$ & $1.426(3)$ & $\mathrm{C} 32-\mathrm{H} 32 \mathrm{~B}$ & 0.9600 \\
\hline $\mathrm{C} 17-\mathrm{C} 22$ & $1.498(3)$ & $\mathrm{C} 32-\mathrm{H} 32 \mathrm{C}$ & 0.9600 \\
\hline C17-Rh1 & $2.217(2)$ & C $33-\mathrm{H} 33 \mathrm{~A}$ & 0.9600 \\
\hline $\mathrm{C} 18-\mathrm{C} 23$ & $1.499(3)$ & C33-H33B & 0.9600 \\
\hline C18-Rh1 & $2.2143(19)$ & $\mathrm{C} 33-\mathrm{H} 33 \mathrm{C}$ & 0.9600 \\
\hline C19-H19A & 0.9600 & $\mathrm{~N} 1-\mathrm{Rh} 1$ & $2.0696(17)$ \\
\hline C19-H19B & 0.9600 & $\mathrm{Rh} 1-\mathrm{Rh} 2$ & $2.7306(2)$ \\
\hline $\mathrm{C} 19-\mathrm{H} 19 \mathrm{C}$ & 0.9600 & $\mathrm{Rh} 2-\mathrm{H} 2 \mathrm{~A}$ & $1.50(2)$ \\
\hline $\mathrm{N} 1-\mathrm{C} 1-\mathrm{C} 2$ & $123.54(19)$ & $\mathrm{C} 30-\mathrm{C} 25-\mathrm{Rh} 2$ & $127.75(15)$ \\
\hline $\mathrm{N} 1-\mathrm{C} 1-\mathrm{C} 6$ & $114.38(18)$ & $\mathrm{C} 27-\mathrm{C} 26-\mathrm{C} 25$ & $108.98(18)$ \\
\hline $\mathrm{C} 2-\mathrm{C} 1-\mathrm{C} 6$ & $122.01(18)$ & $\mathrm{C} 27-\mathrm{C} 26-\mathrm{C} 31$ & $125.76(19)$ \\
\hline $\mathrm{C} 3-\mathrm{C} 2-\mathrm{C} 1$ & $117.45(19)$ & $\mathrm{C} 25-\mathrm{C} 26-\mathrm{C} 31$ & $125.18(19)$ \\
\hline $\mathrm{C} 3-\mathrm{C} 2-\mathrm{C} 13$ & $125.17(19)$ & $\mathrm{C} 27-\mathrm{C} 26-\mathrm{Rh} 2$ & $73.17(11)$ \\
\hline $\mathrm{C} 1-\mathrm{C} 2-\mathrm{C} 13$ & $117.33(19)$ & $\mathrm{C} 25-\mathrm{C} 26-\mathrm{Rh} 2$ & $69.75(11)$ \\
\hline $\mathrm{C} 4-\mathrm{C} 3-\mathrm{C} 2$ & $119.1(2)$ & $\mathrm{C} 31-\mathrm{C} 26-\mathrm{Rh} 2$ & $125.61(14)$ \\
\hline $\mathrm{C} 4-\mathrm{C} 3-\mathrm{H} 3$ & 120.5 & $\mathrm{C} 26-\mathrm{C} 27-\mathrm{C} 28$ & $107.59(18)$ \\
\hline $\mathrm{C} 2-\mathrm{C} 3-\mathrm{H} 3$ & 120.5 & $\mathrm{C} 26-\mathrm{C} 27-\mathrm{C} 32$ & $125.76(19)$ \\
\hline $\mathrm{C} 3-\mathrm{C} 4-\mathrm{C} 5$ & $119.9(2)$ & $\mathrm{C} 28-\mathrm{C} 27-\mathrm{C} 32$ & $126.46(19)$ \\
\hline $\mathrm{C} 3-\mathrm{C} 4-\mathrm{H} 4$ & 120.1 & $\mathrm{C} 26-\mathrm{C} 27-\mathrm{Rh} 2$ & $70.62(11)$ \\
\hline $\mathrm{C} 5-\mathrm{C} 4-\mathrm{H} 4$ & 120.1 & $\mathrm{C} 28-\mathrm{C} 27-\mathrm{Rh} 2$ & $67.79(11)$ \\
\hline $\mathrm{N} 1-\mathrm{C} 5-\mathrm{C} 4$ & $123.2(2)$ & $\mathrm{C} 32-\mathrm{C} 27-\mathrm{Rh} 2$ & $130.77(14)$ \\
\hline $\mathrm{N} 1-\mathrm{C} 5-\mathrm{H} 5$ & 118.4 & $\mathrm{C} 27-\mathrm{C} 28-\mathrm{C} 24$ & $107.92(18)$ \\
\hline $\mathrm{C} 4-\mathrm{C} 5-\mathrm{H} 5$ & 118.4 & $\mathrm{C} 27-\mathrm{C} 28-\mathrm{C} 33$ & $125.78(19)$ \\
\hline $\mathrm{C} 11-\mathrm{C} 6-\mathrm{C} 1$ & $119.68(19)$ & $\mathrm{C} 24-\mathrm{C} 28-\mathrm{C} 33$ & $125.91(19)$ \\
\hline $\mathrm{C} 11-\mathrm{C} 6-\mathrm{C} 7$ & $124.37(19)$ & $\mathrm{C} 27-\mathrm{C} 28-\mathrm{Rh} 2$ & $75.26(12)$ \\
\hline $\mathrm{C} 1-\mathrm{C} 6-\mathrm{C} 7$ & $115.89(18)$ & $\mathrm{C} 24-\mathrm{C} 28-\mathrm{Rh} 2$ & $70.20(11)$ \\
\hline $\mathrm{C} 8-\mathrm{C} 7-\mathrm{C} 6$ & $115.72(18)$ & $\mathrm{C} 33-\mathrm{C} 28-\mathrm{Rh} 2$ & $125.80(14)$ \\
\hline $\mathrm{C} 8-\mathrm{C} 7-\mathrm{Rh} 1$ & $130.42(15)$ & $\mathrm{C} 24-\mathrm{C} 29-\mathrm{H} 29 \mathrm{~A}$ & 109.5 \\
\hline
\end{tabular}




\begin{tabular}{|c|c|c|c|}
\hline $\mathrm{C} 6-\mathrm{C} 7-\mathrm{Rh} 1$ & $113.85(14)$ & $\mathrm{C} 24-\mathrm{C} 29-\mathrm{H} 29 \mathrm{~B}$ & 109.5 \\
\hline $\mathrm{C} 8-\mathrm{C} 7-\mathrm{Rh} 2$ & $78.74(12)$ & $\mathrm{H} 29 \mathrm{~A}-\mathrm{C} 29-\mathrm{H} 29 \mathrm{~B}$ & 109.5 \\
\hline $\mathrm{C} 6-\mathrm{C} 7-\mathrm{Rh} 2$ & $111.10(13)$ & $\mathrm{C} 24-\mathrm{C} 29-\mathrm{H} 29 \mathrm{C}$ & 109.5 \\
\hline $\mathrm{Rh} 1-\mathrm{C} 7-\mathrm{Rh} 2$ & $83.02(7)$ & $\mathrm{H} 29 \mathrm{~A}-\mathrm{C} 29-\mathrm{H} 29 \mathrm{C}$ & 109.5 \\
\hline $\mathrm{C} 7-\mathrm{C} 8-\mathrm{C} 9$ & $119.55(19)$ & $\mathrm{H} 29 \mathrm{~B}-\mathrm{C} 29-\mathrm{H} 29 \mathrm{C}$ & 109.5 \\
\hline $\mathrm{C} 7-\mathrm{C} 8-\mathrm{Rh} 2$ & $64.13(11)$ & $\mathrm{C} 25-\mathrm{C} 30-\mathrm{H} 30 \mathrm{~A}$ & 109.5 \\
\hline $\mathrm{C} 9-\mathrm{C} 8-\mathrm{Rh} 2$ & $120.02(14)$ & $\mathrm{C} 25-\mathrm{C} 30-\mathrm{H} 30 \mathrm{~B}$ & 109.5 \\
\hline $\mathrm{C} 7-\mathrm{C} 8-\mathrm{H} 8$ & 120.2 & $\mathrm{H} 30 \mathrm{~A}-\mathrm{C} 30-\mathrm{H} 30 \mathrm{~B}$ & 109.5 \\
\hline $\mathrm{C} 9-\mathrm{C} 8-\mathrm{H} 8$ & 120.2 & $\mathrm{C} 25-\mathrm{C} 30-\mathrm{H} 30 \mathrm{C}$ & 109.5 \\
\hline $\mathrm{Rh} 2-\mathrm{C} 8-\mathrm{H} 8$ & 86.4 & $\mathrm{H} 30 \mathrm{~A}-\mathrm{C} 30-\mathrm{H} 30 \mathrm{C}$ & 109.5 \\
\hline $\mathrm{C} 10-\mathrm{C} 9-\mathrm{C} 8$ & $122.3(2)$ & $\mathrm{H} 30 \mathrm{~B}-\mathrm{C} 30-\mathrm{H} 30 \mathrm{C}$ & 109.5 \\
\hline $\mathrm{C} 10-\mathrm{C} 9-\mathrm{H} 9$ & 118.8 & $\mathrm{C} 26-\mathrm{C} 31-\mathrm{H} 31 \mathrm{~A}$ & 109.5 \\
\hline $\mathrm{C} 8-\mathrm{C} 9-\mathrm{H} 9$ & 118.8 & $\mathrm{C} 26-\mathrm{C} 31-\mathrm{H} 31 \mathrm{~B}$ & 109.5 \\
\hline $\mathrm{C} 9-\mathrm{C} 10-\mathrm{C} 11$ & $120.49(19)$ & $\mathrm{H} 31 \mathrm{~A}-\mathrm{C} 31-\mathrm{H} 31 \mathrm{~B}$ & 109.5 \\
\hline $\mathrm{C} 9-\mathrm{C} 10-\mathrm{H} 10$ & 119.8 & $\mathrm{C} 26-\mathrm{C} 31-\mathrm{H} 31 \mathrm{C}$ & 109.5 \\
\hline $\mathrm{C} 11-\mathrm{C} 10-\mathrm{H} 10$ & 119.8 & $\mathrm{H} 31 \mathrm{~A}-\mathrm{C} 31-\mathrm{H} 31 \mathrm{C}$ & 109.5 \\
\hline $\mathrm{C} 6-\mathrm{C} 11-\mathrm{C} 10$ & $117.41(19)$ & $\mathrm{H} 31 \mathrm{~B}-\mathrm{C} 31-\mathrm{H} 31 \mathrm{C}$ & 109.5 \\
\hline $\mathrm{C} 6-\mathrm{C} 11-\mathrm{C} 12$ & $118.27(19)$ & $\mathrm{C} 27-\mathrm{C} 32-\mathrm{H} 32 \mathrm{~A}$ & 109.5 \\
\hline $\mathrm{C} 10-\mathrm{C} 11-\mathrm{C} 12$ & $124.29(19)$ & $\mathrm{C} 27-\mathrm{C} 32-\mathrm{H} 32 \mathrm{~B}$ & 109.5 \\
\hline $\mathrm{C} 13-\mathrm{C} 12-\mathrm{C} 11$ & $121.76(19)$ & $\mathrm{H} 32 \mathrm{~A}-\mathrm{C} 32-\mathrm{H} 32 \mathrm{~B}$ & 109.5 \\
\hline $\mathrm{C} 13-\mathrm{C} 12-\mathrm{H} 12$ & 119.1 & $\mathrm{C} 27-\mathrm{C} 32-\mathrm{H} 32 \mathrm{C}$ & 109.5 \\
\hline $\mathrm{C} 11-\mathrm{C} 12-\mathrm{H} 12$ & 119.1 & $\mathrm{H} 32 \mathrm{~A}-\mathrm{C} 32-\mathrm{H} 32 \mathrm{C}$ & 109.5 \\
\hline $\mathrm{C} 12-\mathrm{C} 13-\mathrm{C} 2$ & $120.9(2)$ & $\mathrm{H} 32 \mathrm{~B}-\mathrm{C} 32-\mathrm{H} 32 \mathrm{C}$ & 109.5 \\
\hline $\mathrm{C} 12-\mathrm{C} 13-\mathrm{H} 13$ & 119.6 & $\mathrm{C} 28-\mathrm{C} 33-\mathrm{H} 33 \mathrm{~A}$ & 109.5 \\
\hline $\mathrm{C} 2-\mathrm{C} 13-\mathrm{H} 13$ & 119.6 & $\mathrm{C} 28-\mathrm{C} 33-\mathrm{H} 33 \mathrm{~B}$ & 109.5 \\
\hline $\mathrm{C} 18-\mathrm{C} 14-\mathrm{C} 15$ & $107.82(18)$ & $\mathrm{H} 33 \mathrm{~A}-\mathrm{C} 33-\mathrm{H} 33 \mathrm{~B}$ & 109.5 \\
\hline $\mathrm{C} 18-\mathrm{C} 14-\mathrm{C} 19$ & $124.78(19)$ & $\mathrm{C} 28-\mathrm{C} 33-\mathrm{H} 33 \mathrm{C}$ & 109.5 \\
\hline $\mathrm{C} 15-\mathrm{C} 14-\mathrm{C} 19$ & $126.49(19)$ & H33A-C33-H33C & 109.5 \\
\hline $\mathrm{C} 18-\mathrm{C} 14-\mathrm{Rh} 1$ & $72.46(11)$ & $\mathrm{H} 33 \mathrm{~B}-\mathrm{C} 33-\mathrm{H} 33 \mathrm{C}$ & 109.5 \\
\hline $\mathrm{C} 15-\mathrm{C} 14-\mathrm{Rh} 1$ & $73.60(11)$ & $\mathrm{C} 5-\mathrm{N} 1-\mathrm{C} 1$ & $116.74(18)$ \\
\hline $\mathrm{C} 19-\mathrm{C} 14-\mathrm{Rh} 1$ & $128.16(14)$ & $\mathrm{C} 5-\mathrm{N} 1-\mathrm{Rh} 1$ & $128.26(14)$ \\
\hline $\mathrm{C} 16-\mathrm{C} 15-\mathrm{C} 14$ & $108.16(18)$ & $\mathrm{C} 1-\mathrm{N} 1-\mathrm{Rh} 1$ & $114.80(13)$ \\
\hline $\mathrm{C} 16-\mathrm{C} 15-\mathrm{C} 20$ & $125.30(19)$ & $\mathrm{C} 7-\mathrm{Rh} 1-\mathrm{N} 1$ & $79.95(7)$ \\
\hline $\mathrm{C} 14-\mathrm{C} 15-\mathrm{C} 20$ & $126.39(19)$ & $\mathrm{C} 7-\mathrm{Rh} 1-\mathrm{C} 14$ & $109.57(8)$ \\
\hline $\mathrm{C} 16-\mathrm{C} 15-\mathrm{Rh} 1$ & $72.21(11)$ & $\mathrm{N} 1-\mathrm{Rh} 1-\mathrm{C} 14$ & $162.54(7)$ \\
\hline $\mathrm{C} 14-\mathrm{C} 15-\mathrm{Rh} 1$ & $68.19(11)$ & $\mathrm{C} 7-\mathrm{Rh} 1-\mathrm{C} 18$ & $113.54(8)$ \\
\hline $\mathrm{C} 20-\mathrm{C} 15-\mathrm{Rh} 1$ & $128.71(14)$ & $\mathrm{N} 1-\mathrm{Rh} 1-\mathrm{C} 18$ & $125.00(7)$ \\
\hline
\end{tabular}




\begin{tabular}{|c|c|c|c|}
\hline $\mathrm{C} 15-\mathrm{C} 16-\mathrm{C} 17$ & $107.77(18)$ & $\mathrm{C} 14-\mathrm{Rh} 1-\mathrm{C} 18$ & $38.14(7)$ \\
\hline $\mathrm{C} 15-\mathrm{C} 16-\mathrm{C} 21$ & $125.51(19)$ & $\mathrm{C} 7-\mathrm{Rh} 1-\mathrm{C} 17$ & $143.17(8)$ \\
\hline $\mathrm{C} 17-\mathrm{C} 16-\mathrm{C} 21$ & $126.63(19)$ & $\mathrm{N} 1-\mathrm{Rh} 1-\mathrm{C} 17$ & $100.06(7)$ \\
\hline $\mathrm{C} 15-\mathrm{C} 16-\mathrm{Rh} 1$ & $71.19(11)$ & $\mathrm{C} 14-\mathrm{Rh} 1-\mathrm{C} 17$ & $63.39(8)$ \\
\hline $\mathrm{C} 17-\mathrm{C} 16-\mathrm{Rh} 1$ & $69.59(11)$ & $\mathrm{C} 18-\mathrm{Rh} 1-\mathrm{C} 17$ & $37.53(7)$ \\
\hline $\mathrm{C} 21-\mathrm{C} 16-\mathrm{Rh} 1$ & $127.40(14)$ & $\mathrm{C} 7-\mathrm{Rh} 1-\mathrm{C} 15$ & $135.84(8)$ \\
\hline $\mathrm{C} 18-\mathrm{C} 17-\mathrm{C} 16$ & $108.51(18)$ & N1-Rh1-C15 & $140.82(7)$ \\
\hline $\mathrm{C} 18-\mathrm{C} 17-\mathrm{C} 22$ & $126.02(19)$ & $\mathrm{C} 14-\mathrm{Rh} 1-\mathrm{C} 15$ & $38.21(7)$ \\
\hline $\mathrm{C} 16-\mathrm{C} 17-\mathrm{C} 22$ & $125.15(19)$ & $\mathrm{C} 18-\mathrm{Rh} 1-\mathrm{C} 15$ & $62.96(7)$ \\
\hline $\mathrm{C} 18-\mathrm{C} 17-\mathrm{Rh} 1$ & $71.12(11)$ & C17-Rh1-C15 & $62.34(7)$ \\
\hline $\mathrm{C} 16-\mathrm{C} 17-\mathrm{Rh} 1$ & $72.76(11)$ & $\mathrm{C} 7-\mathrm{Rh} 1-\mathrm{C} 16$ & $172.15(8)$ \\
\hline $\mathrm{C} 22-\mathrm{C} 17-\mathrm{Rh} 1$ & $127.13(14)$ & $\mathrm{N} 1-\mathrm{Rh} 1-\mathrm{C} 16$ & $107.88(7)$ \\
\hline $\mathrm{C} 17-\mathrm{C} 18-\mathrm{C} 14$ & $107.59(18)$ & $\mathrm{C} 14-\mathrm{Rh} 1-\mathrm{C} 16$ & $63.04(7)$ \\
\hline $\mathrm{C} 17-\mathrm{C} 18-\mathrm{C} 23$ & $127.17(19)$ & $\mathrm{C} 18-\mathrm{Rh} 1-\mathrm{C} 16$ & $62.76(7)$ \\
\hline $\mathrm{C} 14-\mathrm{C} 18-\mathrm{C} 23$ & $124.99(19)$ & $\mathrm{C} 17-\mathrm{Rh} 1-\mathrm{C} 16$ & $37.65(7)$ \\
\hline $\mathrm{C} 17-\mathrm{C} 18-\mathrm{Rh} 1$ & $71.35(11)$ & $\mathrm{C} 15-\mathrm{Rh} 1-\mathrm{C} 16$ & $36.60(7)$ \\
\hline $\mathrm{C} 14-\mathrm{C} 18-\mathrm{Rh} 1$ & $69.40(11)$ & $\mathrm{C} 7-\mathrm{Rh} 1-\mathrm{Rh} 2$ & $50.45(5)$ \\
\hline $\mathrm{C} 23-\mathrm{C} 18-\mathrm{Rh} 1$ & $129.04(14)$ & $\mathrm{N} 1-\mathrm{Rh} 1-\mathrm{Rh} 2$ & $92.46(5)$ \\
\hline $\mathrm{C} 14-\mathrm{C} 19-\mathrm{H} 19 \mathrm{~A}$ & 109.5 & $\mathrm{C} 14-\mathrm{Rh} 1-\mathrm{Rh} 2$ & $104.89(5)$ \\
\hline $\mathrm{C} 14-\mathrm{C} 19-\mathrm{H} 19 \mathrm{~B}$ & 109.5 & $\mathrm{C} 18-\mathrm{Rh} 1-\mathrm{Rh} 2$ & $138.47(5)$ \\
\hline H19A-C19-H19B & 109.5 & $\mathrm{C} 17-\mathrm{Rh} 1-\mathrm{Rh} 2$ & $162.92(5)$ \\
\hline $\mathrm{C} 14-\mathrm{C} 19-\mathrm{H} 19 \mathrm{C}$ & 109.5 & $\mathrm{C} 15-\mathrm{Rh} 1-\mathrm{Rh} 2$ & $100.67(5)$ \\
\hline $\mathrm{H} 19 \mathrm{~A}-\mathrm{C} 19-\mathrm{H} 19 \mathrm{C}$ & 109.5 & $\mathrm{C} 16-\mathrm{Rh} 1-\mathrm{Rh} 2$ & $127.00(5)$ \\
\hline $\mathrm{H} 19 \mathrm{~B}-\mathrm{C} 19-\mathrm{H} 19 \mathrm{C}$ & 109.5 & $\mathrm{C} 7-\mathrm{Rh} 2-\mathrm{C} 24$ & $170.03(8)$ \\
\hline $\mathrm{C} 15-\mathrm{C} 20-\mathrm{H} 20 \mathrm{~A}$ & 109.5 & $\mathrm{C} 7-\mathrm{Rh} 2-\mathrm{C} 28$ & $131.85(8)$ \\
\hline $\mathrm{C} 15-\mathrm{C} 20-\mathrm{H} 20 \mathrm{~B}$ & 109.5 & $\mathrm{C} 24-\mathrm{Rh} 2-\mathrm{C} 28$ & $38.27(8)$ \\
\hline $\mathrm{H} 20 \mathrm{~A}-\mathrm{C} 20-\mathrm{H} 20 \mathrm{~B}$ & 109.5 & $\mathrm{C} 7-\mathrm{Rh} 2-\mathrm{C} 25$ & $147.18(8)$ \\
\hline $\mathrm{C} 15-\mathrm{C} 20-\mathrm{H} 20 \mathrm{C}$ & 109.5 & $\mathrm{C} 24-\mathrm{Rh} 2-\mathrm{C} 25$ & $37.71(8)$ \\
\hline $\mathrm{H} 20 \mathrm{~A}-\mathrm{C} 20-\mathrm{H} 20 \mathrm{C}$ & 109.5 & $\mathrm{C} 28-\mathrm{Rh} 2-\mathrm{C} 25$ & $63.23(8)$ \\
\hline $\mathrm{H} 20 \mathrm{~B}-\mathrm{C} 20-\mathrm{H} 20 \mathrm{C}$ & 109.5 & $\mathrm{C} 7-\mathrm{Rh} 2-\mathrm{C} 26$ & $116.84(7)$ \\
\hline $\mathrm{C} 16-\mathrm{C} 21-\mathrm{H} 21 \mathrm{~A}$ & 109.5 & $\mathrm{C} 24-\mathrm{Rh} 2-\mathrm{C} 26$ & $62.27(8)$ \\
\hline $\mathrm{C} 16-\mathrm{C} 21-\mathrm{H} 21 \mathrm{~B}$ & 109.5 & $\mathrm{C} 28-\mathrm{Rh} 2-\mathrm{C} 26$ & $61.91(8)$ \\
\hline $\mathrm{H} 21 \mathrm{~A}-\mathrm{C} 21-\mathrm{H} 21 \mathrm{~B}$ & 109.5 & $\mathrm{C} 25-\mathrm{Rh} 2-\mathrm{C} 26$ & $37.30(7)$ \\
\hline $\mathrm{C} 16-\mathrm{C} 21-\mathrm{H} 21 \mathrm{C}$ & 109.5 & $\mathrm{C} 7-\mathrm{Rh} 2-\mathrm{C} 27$ & $110.70(7)$ \\
\hline $\mathrm{H} 21 \mathrm{~A}-\mathrm{C} 21-\mathrm{H} 21 \mathrm{C}$ & 109.5 & $\mathrm{C} 24-\mathrm{Rh} 2-\mathrm{C} 27$ & $62.21(7)$ \\
\hline $\mathrm{H} 21 \mathrm{~B}-\mathrm{C} 21-\mathrm{H} 21 \mathrm{C}$ & 109.5 & $\mathrm{C} 28-\mathrm{Rh} 2-\mathrm{C} 27$ & $36.95(7)$ \\
\hline $\mathrm{C} 17-\mathrm{C} 22-\mathrm{H} 22 \mathrm{~A}$ & 109.5 & $\mathrm{C} 25-\mathrm{Rh} 2-\mathrm{C} 27$ & $61.83(7)$ \\
\hline
\end{tabular}




\begin{tabular}{|c|c|c|c|}
\hline $\mathrm{C} 17-\mathrm{C} 22-\mathrm{H} 22 \mathrm{~B}$ & 109.5 & $\mathrm{C} 26-\mathrm{Rh} 2-\mathrm{C} 27$ & $36.22(7)$ \\
\hline $\mathrm{H} 22 \mathrm{~A}-\mathrm{C} 22-\mathrm{H} 22 \mathrm{~B}$ & 109.5 & $\mathrm{C} 7-\mathrm{Rh} 2-\mathrm{C} 8$ & $37.13(7)$ \\
\hline $\mathrm{C} 17-\mathrm{C} 22-\mathrm{H} 22 \mathrm{C}$ & 109.5 & $\mathrm{C} 24-\mathrm{Rh} 2-\mathrm{C} 8$ & $152.61(8)$ \\
\hline $\mathrm{H} 22 \mathrm{~A}-\mathrm{C} 22-\mathrm{H} 22 \mathrm{C}$ & 109.5 & $\mathrm{C} 28-\mathrm{Rh} 2-\mathrm{C} 8$ & $163.75(8)$ \\
\hline $\mathrm{H} 22 \mathrm{~B}-\mathrm{C} 22-\mathrm{H} 22 \mathrm{C}$ & 109.5 & $\mathrm{C} 25-\mathrm{Rh} 2-\mathrm{C} 8$ & $119.26(7)$ \\
\hline $\mathrm{C} 18-\mathrm{C} 23-\mathrm{H} 23 \mathrm{~A}$ & 109.5 & $\mathrm{C} 26-\mathrm{Rh} 2-\mathrm{C} 8$ & $109.37(7)$ \\
\hline $\mathrm{C} 18-\mathrm{C} 23-\mathrm{H} 23 \mathrm{~B}$ & 109.5 & $\mathrm{C} 27-\mathrm{Rh} 2-\mathrm{C} 8$ & $127.94(7)$ \\
\hline $\mathrm{H} 23 \mathrm{~A}-\mathrm{C} 23-\mathrm{H} 23 \mathrm{~B}$ & 109.5 & $\mathrm{C} 7-\mathrm{Rh} 2-\mathrm{Rh} 1$ & $46.52(5)$ \\
\hline $\mathrm{C} 18-\mathrm{C} 23-\mathrm{H} 23 \mathrm{C}$ & 109.5 & $\mathrm{C} 24-\mathrm{Rh} 2-\mathrm{Rh} 1$ & $127.54(6)$ \\
\hline $\mathrm{H} 23 \mathrm{~A}-\mathrm{C} 23-\mathrm{H} 23 \mathrm{C}$ & 109.5 & $\mathrm{C} 28-\mathrm{Rh} 2-\mathrm{Rh} 1$ & $102.90(5)$ \\
\hline $\mathrm{H} 23 \mathrm{~B}-\mathrm{C} 23-\mathrm{H} 23 \mathrm{C}$ & 109.5 & $\mathrm{C} 25-\mathrm{Rh} 2-\mathrm{Rh} 1$ & $164.92(5)$ \\
\hline $\mathrm{C} 25-\mathrm{C} 24-\mathrm{C} 28$ & $108.26(18)$ & $\mathrm{C} 26-\mathrm{Rh} 2-\mathrm{Rh} 1$ & $143.31(5)$ \\
\hline $\mathrm{C} 25-\mathrm{C} 24-\mathrm{C} 29$ & $125.7(2)$ & $\mathrm{C} 27-\mathrm{Rh} 2-\mathrm{Rh} 1$ & $111.30(5)$ \\
\hline $\mathrm{C} 28-\mathrm{C} 24-\mathrm{C} 29$ & $125.3(2)$ & $\mathrm{C} 8-\mathrm{Rh} 2-\mathrm{Rh} 1$ & $75.75(5)$ \\
\hline $\mathrm{C} 25-\mathrm{C} 24-\mathrm{Rh} 2$ & $72.67(11)$ & $\mathrm{C} 7-\mathrm{Rh} 2-\mathrm{H} 2 \mathrm{~A}$ & $91.2(9)$ \\
\hline $\mathrm{C} 28-\mathrm{C} 24-\mathrm{Rh} 2$ & $71.52(11)$ & $\mathrm{C} 24-\mathrm{Rh} 2-\mathrm{H} 2 \mathrm{~A}$ & $93.6(9)$ \\
\hline $\mathrm{C} 29-\mathrm{C} 24-\mathrm{Rh} 2$ & $129.00(14)$ & $\mathrm{C} 28-\mathrm{Rh} 2-\mathrm{H} 2 \mathrm{~A}$ & $115.2(9)$ \\
\hline $\mathrm{C} 24-\mathrm{C} 25-\mathrm{C} 26$ & $107.13(18)$ & $\mathrm{C} 25-\mathrm{Rh} 2-\mathrm{H} 2 \mathrm{~A}$ & $108.3(9)$ \\
\hline $\mathrm{C} 24-\mathrm{C} 25-\mathrm{C} 30$ & $126.7(2)$ & $\mathrm{C} 26-\mathrm{Rh} 2-\mathrm{H} 2 \mathrm{~A}$ & $145.1(9)$ \\
\hline $\mathrm{C} 26-\mathrm{C} 25-\mathrm{C} 30$ & $125.8(2)$ & $\mathrm{C} 27-\mathrm{Rh} 2-\mathrm{H} 2 \mathrm{~A}$ & $152.1(9)$ \\
\hline $\mathrm{C} 24-\mathrm{C} 25-\mathrm{Rh} 2$ & $69.62(11)$ & $\mathrm{C} 8-\mathrm{Rh} 2-\mathrm{H} 2 \mathrm{~A}$ & $80.0(9)$ \\
\hline $\mathrm{C} 26-\mathrm{C} 25-\mathrm{Rh} 2$ & $72.96(11)$ & $\mathrm{Rh} 1-\mathrm{Rh} 2-\mathrm{H} 2 \mathrm{~A}$ & $71.1(9)$ \\
\hline $\mathrm{N} 1-\mathrm{C} 1-\mathrm{C} 2-\mathrm{C} 3$ & $-0.1(3)$ & $\begin{array}{l}\mathrm{C} 22-\mathrm{C} 17-\mathrm{C} 18- \\
\mathrm{C} 14\end{array}$ & $-177.08(19)$ \\
\hline $\mathrm{C} 6-\mathrm{C} 1-\mathrm{C} 2-\mathrm{C} 3$ & $-176.90(18)$ & $\begin{array}{l}\text { Rh1-C17-C18- } \\
\text { C14 }\end{array}$ & $60.23(13)$ \\
\hline $\mathrm{N} 1-\mathrm{C} 1-\mathrm{C} 2-\mathrm{C} 13$ & $177.41(17)$ & $\begin{array}{l}\mathrm{C} 16-\mathrm{C} 17-\mathrm{C} 18- \\
\mathrm{C} 23\end{array}$ & $171.08(19)$ \\
\hline $\mathrm{C} 6-\mathrm{C} 1-\mathrm{C} 2-\mathrm{C} 13$ & $0.6(3)$ & $\begin{array}{l}\mathrm{C} 22-\mathrm{C} 17-\mathrm{C} 18- \\
\mathrm{C} 23\end{array}$ & $-2.6(3)$ \\
\hline $\mathrm{C} 1-\mathrm{C} 2-\mathrm{C} 3-\mathrm{C} 4$ & $1.2(3)$ & $\begin{array}{l}\mathrm{Rh} 1-\mathrm{C} 17-\mathrm{C} 18- \\
\mathrm{C} 23\end{array}$ & $-125.3(2)$ \\
\hline $\mathrm{C} 13-\mathrm{C} 2-\mathrm{C} 3-\mathrm{C} 4$ & $-176.1(2)$ & $\begin{array}{l}\text { C16-C17-C18- } \\
\text { Rh1 }\end{array}$ & $-63.59(13)$ \\
\hline $\mathrm{C} 2-\mathrm{C} 3-\mathrm{C} 4-\mathrm{C} 5$ & $-0.6(3)$ & $\begin{array}{l}\text { C22-C17-C18- } \\
\text { Rh1 }\end{array}$ & $122.7(2)$ \\
\hline $\mathrm{C} 3-\mathrm{C} 4-\mathrm{C} 5-\mathrm{N} 1$ & $-1.1(3)$ & $\begin{array}{l}\text { C15-C14-C18- } \\
\text { C17 }\end{array}$ & $4.2(2)$ \\
\hline $\mathrm{N} 1-\mathrm{C} 1-\mathrm{C} 6-\mathrm{C} 11$ & $-174.99(17)$ & $\mathrm{C} 19-\mathrm{C} 14-\mathrm{C} 18-$ & $173.81(18)$ \\
\hline
\end{tabular}




\begin{tabular}{|c|c|c|c|}
\hline & & $\mathrm{C} 17$ & \\
\hline $\mathrm{C} 2-\mathrm{C} 1-\mathrm{C} 6-\mathrm{C} 11$ & $2.1(3)$ & $\begin{array}{l}\mathrm{Rh} 1-\mathrm{C} 14-\mathrm{C} 18- \\
\mathrm{C} 17\end{array}$ & $-61.47(13)$ \\
\hline $\mathrm{N} 1-\mathrm{C} 1-\mathrm{C} 6-\mathrm{C} 7$ & $2.2(2)$ & $\begin{array}{l}\mathrm{C} 15-\mathrm{C} 14-\mathrm{C} 18- \\
\mathrm{C} 23\end{array}$ & $-170.44(18)$ \\
\hline $\mathrm{C} 2-\mathrm{C} 1-\mathrm{C} 6-\mathrm{C} 7$ & $179.24(17)$ & $\begin{array}{l}\mathrm{C} 19-\mathrm{C} 14-\mathrm{C} 18- \\
\mathrm{C} 23\end{array}$ & $-0.8(3)$ \\
\hline $\mathrm{C} 11-\mathrm{C} 6-\mathrm{C} 7-\mathrm{C} 8$ & $4.2(3)$ & $\begin{array}{l}\mathrm{Rh} 1-\mathrm{C} 14-\mathrm{C} 18- \\
\mathrm{C} 23\end{array}$ & $123.94(19)$ \\
\hline $\mathrm{C} 1-\mathrm{C} 6-\mathrm{C} 7-\mathrm{C} 8$ & $-172.85(17)$ & $\begin{array}{l}\text { C15-C14-C18- } \\
\text { Rh1 }\end{array}$ & $65.63(13)$ \\
\hline $\mathrm{C} 11-\mathrm{C} 6-\mathrm{C} 7-\mathrm{Rh} 1$ & $-176.90(15)$ & $\begin{array}{l}\mathrm{C} 19-\mathrm{C} 14-\mathrm{C} 18- \\
\mathrm{Rh} 1\end{array}$ & $-124.7(2)$ \\
\hline $\mathrm{C} 1-\mathrm{C} 6-\mathrm{C} 7-\mathrm{Rh} 1$ & $6.1(2)$ & $\begin{array}{l}\mathrm{C} 28-\mathrm{C} 24-\mathrm{C} 25- \\
\mathrm{C} 26\end{array}$ & $0.7(2)$ \\
\hline $\mathrm{C} 11-\mathrm{C} 6-\mathrm{C} 7-\mathrm{Rh} 2$ & $91.5(2)$ & $\begin{array}{l}\mathrm{C} 29-\mathrm{C} 24-\mathrm{C} 25- \\
\mathrm{C} 26\end{array}$ & $-170.23(19)$ \\
\hline $\mathrm{C} 1-\mathrm{C} 6-\mathrm{C} 7-\mathrm{Rh} 2$ & $-85.51(18)$ & $\begin{array}{l}\mathrm{Rh} 2-\mathrm{C} 24-\mathrm{C} 25- \\
\mathrm{C} 26\end{array}$ & $63.79(14)$ \\
\hline $\mathrm{C} 6-\mathrm{C} 7-\mathrm{C} 8-\mathrm{C} 9$ & $-3.2(3)$ & $\begin{array}{l}\mathrm{C} 28-\mathrm{C} 24-\mathrm{C} 25- \\
\mathrm{C} 30\end{array}$ & $174.38(19)$ \\
\hline $\mathrm{Rh} 1-\mathrm{C} 7-\mathrm{C} 8-\mathrm{C} 9$ & $178.05(15)$ & $\begin{array}{l}\mathrm{C} 29-\mathrm{C} 24-\mathrm{C} 25- \\
\mathrm{C} 30\end{array}$ & $3.5(3)$ \\
\hline $\mathrm{Rh} 2-\mathrm{C} 7-\mathrm{C} 8-\mathrm{C} 9$ & $-111.36(18)$ & $\begin{array}{l}\mathrm{Rh} 2-\mathrm{C} 24-\mathrm{C} 25- \\
\mathrm{C} 30\end{array}$ & $-122.5(2)$ \\
\hline $\mathrm{C} 6-\mathrm{C} 7-\mathrm{C} 8-\mathrm{Rh} 2$ & $108.15(16)$ & $\begin{array}{l}\mathrm{C} 28-\mathrm{C} 24-\mathrm{C} 25- \\
\mathrm{Rh} 2\end{array}$ & $-63.09(14)$ \\
\hline $\mathrm{Rh} 1-\mathrm{C} 7-\mathrm{C} 8-\mathrm{Rh} 2$ & $-70.59(15)$ & $\begin{array}{l}\mathrm{C} 29-\mathrm{C} 24-\mathrm{C} 25- \\
\mathrm{Rh} 2\end{array}$ & $126.0(2)$ \\
\hline $\mathrm{C} 7-\mathrm{C} 8-\mathrm{C} 9-\mathrm{C} 10$ & $0.4(3)$ & $\begin{array}{l}\mathrm{C} 24-\mathrm{C} 25-\mathrm{C} 26- \\
\mathrm{C} 27\end{array}$ & $1.4(2)$ \\
\hline $\mathrm{Rh} 2-\mathrm{C} 8-\mathrm{C} 9-\mathrm{C} 10$ & $-75.0(2)$ & $\begin{array}{l}\mathrm{C} 30-\mathrm{C} 25-\mathrm{C} 26- \\
\mathrm{C} 27\end{array}$ & $-172.31(19)$ \\
\hline $\mathrm{C} 8-\mathrm{C} 9-\mathrm{C} 10-\mathrm{C} 11$ & $1.9(3)$ & $\begin{array}{l}\mathrm{Rh} 2-\mathrm{C} 25-\mathrm{C} 26- \\
\mathrm{C} 27\end{array}$ & $63.04(14)$ \\
\hline $\mathrm{C} 1-\mathrm{C} 6-\mathrm{C} 11-\mathrm{C} 10$ & $174.86(18)$ & $\begin{array}{l}\mathrm{C} 24-\mathrm{C} 25-\mathrm{C} 26- \\
\mathrm{C} 31\end{array}$ & $178.45(18)$ \\
\hline $\mathrm{C} 7-\mathrm{C} 6-\mathrm{C} 11-\mathrm{C} 10$ & $-2.0(3)$ & $\begin{array}{l}\mathrm{C} 30-\mathrm{C} 25-\mathrm{C} 26- \\
\mathrm{C} 31\end{array}$ & $4.7(3)$ \\
\hline $\mathrm{C} 1-\mathrm{C} 6-\mathrm{C} 11-\mathrm{C} 12$ & $-3.4(3)$ & $\begin{array}{l}\mathrm{Rh} 2-\mathrm{C} 25-\mathrm{C} 26- \\
\mathrm{C} 31\end{array}$ & $-120.0(2)$ \\
\hline $\mathrm{C} 7-\mathrm{C} 6-\mathrm{C} 11-\mathrm{C} 12$ & $179.69(18)$ & $\begin{array}{l}\mathrm{C} 24-\mathrm{C} 25-\mathrm{C} 26- \\
\mathrm{Rh} 2\end{array}$ & $-61.60(13)$ \\
\hline $\mathrm{C} 9-\mathrm{C} 10-\mathrm{C} 11-\mathrm{C} 6$ & $-1.1(3)$ & $\begin{array}{l}\mathrm{C} 30-\mathrm{C} 25-\mathrm{C} 26- \\
\mathrm{Rh} 2\end{array}$ & $124.6(2)$ \\
\hline
\end{tabular}




\begin{tabular}{|c|c|c|c|}
\hline $\mathrm{C} 9-\mathrm{C} 10-\mathrm{C} 11-\mathrm{C} 12$ & $177.1(2)$ & $\begin{array}{l}\mathrm{C} 25-\mathrm{C} 26-\mathrm{C} 27- \\
\mathrm{C} 28\end{array}$ & $-3.0(2)$ \\
\hline $\mathrm{C} 6-\mathrm{C} 11-\mathrm{C} 12-\mathrm{C} 13$ & $2.2(3)$ & $\begin{array}{l}\mathrm{C} 31-\mathrm{C} 26-\mathrm{C} 27- \\
\mathrm{C} 28\end{array}$ & $180.00(19)$ \\
\hline $\begin{array}{l}\mathrm{C} 10-\mathrm{C} 11-\mathrm{C} 12- \\
\mathrm{C} 13\end{array}$ & $-176.0(2)$ & $\begin{array}{l}\mathrm{Rh} 2-\mathrm{C} 26-\mathrm{C} 27- \\
\mathrm{C} 28\end{array}$ & $57.87(13)$ \\
\hline $\mathrm{C} 11-\mathrm{C} 12-\mathrm{C} 13-\mathrm{C} 2$ & $0.5(3)$ & $\begin{array}{l}\mathrm{C} 25-\mathrm{C} 26-\mathrm{C} 27- \\
\mathrm{C} 32\end{array}$ & $172.27(18)$ \\
\hline $\mathrm{C} 3-\mathrm{C} 2-\mathrm{C} 13-\mathrm{C} 12$ & $175.4(2)$ & $\begin{array}{l}\mathrm{C} 31-\mathrm{C} 26-\mathrm{C} 27- \\
\mathrm{C} 32\end{array}$ & $-4.7(3)$ \\
\hline $\mathrm{C} 1-\mathrm{C} 2-\mathrm{C} 13-\mathrm{C} 12$ & $-1.9(3)$ & $\begin{array}{l}\mathrm{Rh} 2-\mathrm{C} 26-\mathrm{C} 27- \\
\mathrm{C} 32\end{array}$ & $-126.85(19)$ \\
\hline $\begin{array}{l}\mathrm{C} 18-\mathrm{C} 14-\mathrm{C} 15- \\
\mathrm{C} 16\end{array}$ & $-3.4(2)$ & $\begin{array}{l}\mathrm{C} 25-\mathrm{C} 26-\mathrm{C} 27- \\
\mathrm{Rh} 2\end{array}$ & $-60.89(14)$ \\
\hline $\begin{array}{l}\mathrm{C} 19-\mathrm{C} 14-\mathrm{C} 15- \\
\mathrm{C} 16\end{array}$ & $-172.84(19)$ & $\begin{array}{l}\mathrm{C} 31-\mathrm{C} 26-\mathrm{C} 27- \\
\mathrm{Rh} 2\end{array}$ & $122.1(2)$ \\
\hline $\begin{array}{l}\mathrm{Rh} 1-\mathrm{C} 14-\mathrm{C} 15- \\
\mathrm{C} 16\end{array}$ & $61.46(14)$ & $\begin{array}{l}\mathrm{C} 26-\mathrm{C} 27-\mathrm{C} 28- \\
\mathrm{C} 24\end{array}$ & $3.4(2)$ \\
\hline $\begin{array}{l}\mathrm{C} 18-\mathrm{C} 14-\mathrm{C} 15- \\
\mathrm{C} 20\end{array}$ & $172.31(19)$ & $\begin{array}{l}\mathrm{C} 32-\mathrm{C} 27-\mathrm{C} 28- \\
\mathrm{C} 24\end{array}$ & $-171.83(18)$ \\
\hline $\begin{array}{l}\mathrm{C} 19-\mathrm{C} 14-\mathrm{C} 15- \\
\mathrm{C} 20\end{array}$ & $2.9(3)$ & $\begin{array}{l}\mathrm{Rh} 2-\mathrm{C} 27-\mathrm{C} 28- \\
\mathrm{C} 24\end{array}$ & 63.05 (13) \\
\hline $\begin{array}{l}\mathrm{Rh} 1-\mathrm{C} 14-\mathrm{C} 15- \\
\mathrm{C} 20\end{array}$ & $-122.8(2)$ & $\begin{array}{l}\mathrm{C} 26-\mathrm{C} 27-\mathrm{C} 28- \\
\mathrm{C} 33\end{array}$ & $176.58(19)$ \\
\hline $\begin{array}{l}\mathrm{C} 18-\mathrm{C} 14-\mathrm{C} 15- \\
\mathrm{Rh} 1\end{array}$ & $-64.87(13)$ & $\begin{array}{l}\mathrm{C} 32-\mathrm{C} 27-\mathrm{C} 28- \\
\mathrm{C} 33\end{array}$ & $1.3(3)$ \\
\hline $\begin{array}{l}\mathrm{C} 19-\mathrm{C} 14-\mathrm{C} 15- \\
\mathrm{Rh} 1\end{array}$ & $125.7(2)$ & $\begin{array}{l}\mathrm{Rh} 2-\mathrm{C} 27-\mathrm{C} 28- \\
\mathrm{C} 33\end{array}$ & $-123.8(2)$ \\
\hline $\begin{array}{l}\mathrm{C} 14-\mathrm{C} 15-\mathrm{C} 16- \\
\mathrm{C} 17\end{array}$ & $1.3(2)$ & $\begin{array}{l}\mathrm{C} 26-\mathrm{C} 27-\mathrm{C} 28- \\
\mathrm{Rh} 2\end{array}$ & $-59.64(14)$ \\
\hline $\begin{array}{l}\mathrm{C} 20-\mathrm{C} 15-\mathrm{C} 16- \\
\mathrm{C} 17\end{array}$ & $-174.45(19)$ & $\begin{array}{l}\mathrm{C} 32-\mathrm{C} 27-\mathrm{C} 28- \\
\mathrm{Rh} 2\end{array}$ & $125.1(2)$ \\
\hline $\begin{array}{l}\mathrm{Rh} 1-\mathrm{C} 15-\mathrm{C} 16- \\
\mathrm{C} 17\end{array}$ & $60.27(13)$ & $\begin{array}{l}\mathrm{C} 25-\mathrm{C} 24-\mathrm{C} 28- \\
\mathrm{C} 27\end{array}$ & $-2.6(2)$ \\
\hline $\begin{array}{l}\mathrm{C} 14-\mathrm{C} 15-\mathrm{C} 16- \\
\mathrm{C} 21\end{array}$ & $178.02(18)$ & $\begin{array}{l}\mathrm{C} 29-\mathrm{C} 24-\mathrm{C} 28- \\
\mathrm{C} 27\end{array}$ & $168.41(19)$ \\
\hline $\begin{array}{l}\mathrm{C} 20-\mathrm{C} 15-\mathrm{C} 16- \\
\mathrm{C} 21\end{array}$ & $2.2(3)$ & $\begin{array}{l}\mathrm{Rh} 2-\mathrm{C} 24-\mathrm{C} 28- \\
\mathrm{C} 27\end{array}$ & $-66.38(14)$ \\
\hline $\begin{array}{l}\mathrm{Rh} 1-\mathrm{C} 15-\mathrm{C} 16- \\
\mathrm{C} 21\end{array}$ & $-123.04(19)$ & $\begin{array}{l}\mathrm{C} 25-\mathrm{C} 24-\mathrm{C} 28- \\
\mathrm{C} 33\end{array}$ & $-175.71(19)$ \\
\hline $\begin{array}{l}\mathrm{C} 14-\mathrm{C} 15-\mathrm{C} 16- \\
\mathrm{Rh} 1\end{array}$ & $-58.94(13)$ & $\begin{array}{l}\mathrm{C} 29-\mathrm{C} 24-\mathrm{C} 28- \\
\mathrm{C} 33\end{array}$ & $-4.7(3)$ \\
\hline $\begin{array}{l}\mathrm{C} 20-\mathrm{C} 15-\mathrm{C} 16- \\
\mathrm{Rh} 1\end{array}$ & $125.3(2)$ & $\begin{array}{l}\mathrm{Rh} 2-\mathrm{C} 24-\mathrm{C} 28- \\
\mathrm{C} 33\end{array}$ & $120.5(2)$ \\
\hline
\end{tabular}




\begin{tabular}{|l|l|l|l|}
\hline $\begin{array}{l}\mathrm{C} 15-\mathrm{C} 16-\mathrm{C} 17- \\
\mathrm{C} 18\end{array}$ & $1.3(2)$ & $\begin{array}{l}\mathrm{C} 25-\mathrm{C} 24-\mathrm{C} 28- \\
\mathrm{R} 22\end{array}$ & $63.83(14)$ \\
\hline $\begin{array}{l}\mathrm{C} 21-\mathrm{C} 16-\mathrm{C} 17- \\
\mathrm{C} 18\end{array}$ & $-175.38(19)$ & $\begin{array}{l}\mathrm{C} 29-\mathrm{C} 24-\mathrm{C} 28- \\
\mathrm{R} 22\end{array}$ & $-125.2(2)$ \\
\hline $\begin{array}{l}\mathrm{R} 1-\mathrm{C} 16-\mathrm{C} 17- \\
\mathrm{C} 18\end{array}$ & $62.54(13)$ & $\mathrm{C} 4-\mathrm{C} 5-\mathrm{N} 1-\mathrm{C} 1$ & $2.1(3)$ \\
\hline $\begin{array}{l}\mathrm{C} 15-\mathrm{C} 16-\mathrm{C} 17- \\
\mathrm{C} 22\end{array}$ & $175.04(18)$ & $\mathrm{C} 4-\mathrm{C} 5-\mathrm{N} 1-\mathrm{Rh} 1$ & $-172.44(15)$ \\
\hline $\begin{array}{l}\mathrm{C} 21-\mathrm{C} 16-\mathrm{C} 17- \\
\mathrm{C} 22\end{array}$ & $-1.6(3)$ & $\mathrm{C} 2-\mathrm{C} 1-\mathrm{N} 1-\mathrm{C} 5$ & $-1.5(3)$ \\
\hline $\begin{array}{l}\mathrm{R} 1-\mathrm{C} 16-\mathrm{C} 17- \\
\mathrm{C} 22\end{array}$ & $-123.7(2)$ & $\mathrm{C} 6-\mathrm{C} 1-\mathrm{N} 1-\mathrm{C} 5$ & $175.50(17)$ \\
\hline $\begin{array}{l}\mathrm{C} 15-\mathrm{C} 16-\mathrm{C} 17- \\
\mathrm{R} 11\end{array}$ & $-61.29(13)$ & $\mathrm{C} 2-\mathrm{C} 1-\mathrm{N} 1-\mathrm{Rh} 1$ & $173.77(15)$ \\
\hline $\begin{array}{l}\mathrm{C} 21-\mathrm{C} 16-\mathrm{C} 17- \\
\mathrm{R} 11\end{array}$ & $122.1(2)$ & $\mathrm{C} 6-\mathrm{C} 1-\mathrm{N} 1-\mathrm{Rh} 1$ & $-9.2(2)$ \\
\hline $\begin{array}{l}\mathrm{C} 16-\mathrm{C} 17-\mathrm{C} 18- \\
\mathrm{C} 14-\end{array}$ & $-3.4(2)$ & & \\
\hline
\end{tabular}

\section{Compound 5}

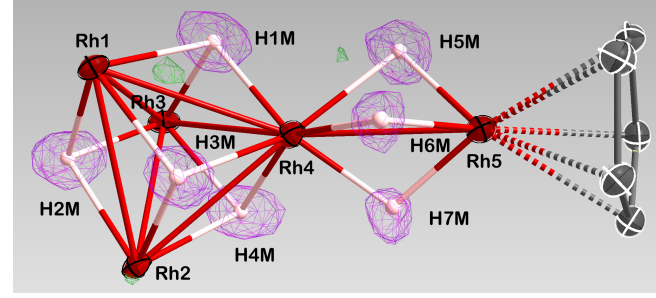

(a)

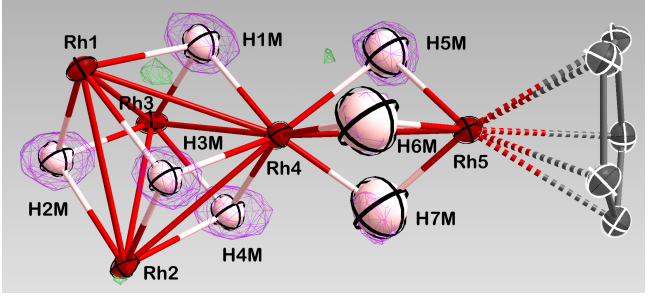

(b)

Figure S49. (a) View of the difference Fourier map showing the nuclear positions for the missing hydrides in $\left(\mathbf{C}_{\mathbf{5}} \mathbf{M e}_{\mathbf{5}}\right)_{\mathbf{4}} \mathbf{R h}_{\mathbf{5}} \mathbf{H}_{7}$. The iso-surfaces (purple) were draw at the 3-sigma level. (b) Overlay of the refined hydride positions in the crystal structure of $\left(\mathrm{C}_{5} \mathbf{M e}_{5}\right)_{4} \mathbf{R h}_{5} \mathrm{H}_{7} \cdot \mathbf{0 . 5 p e n t a n e}$. Atom displacement parameters were shown at the $50 \%$ probability level. Methyl groups on $-\mathrm{C}_{5} \mathrm{Me}_{5}$ and the disordered pentane molecule were omitted for clarity. 


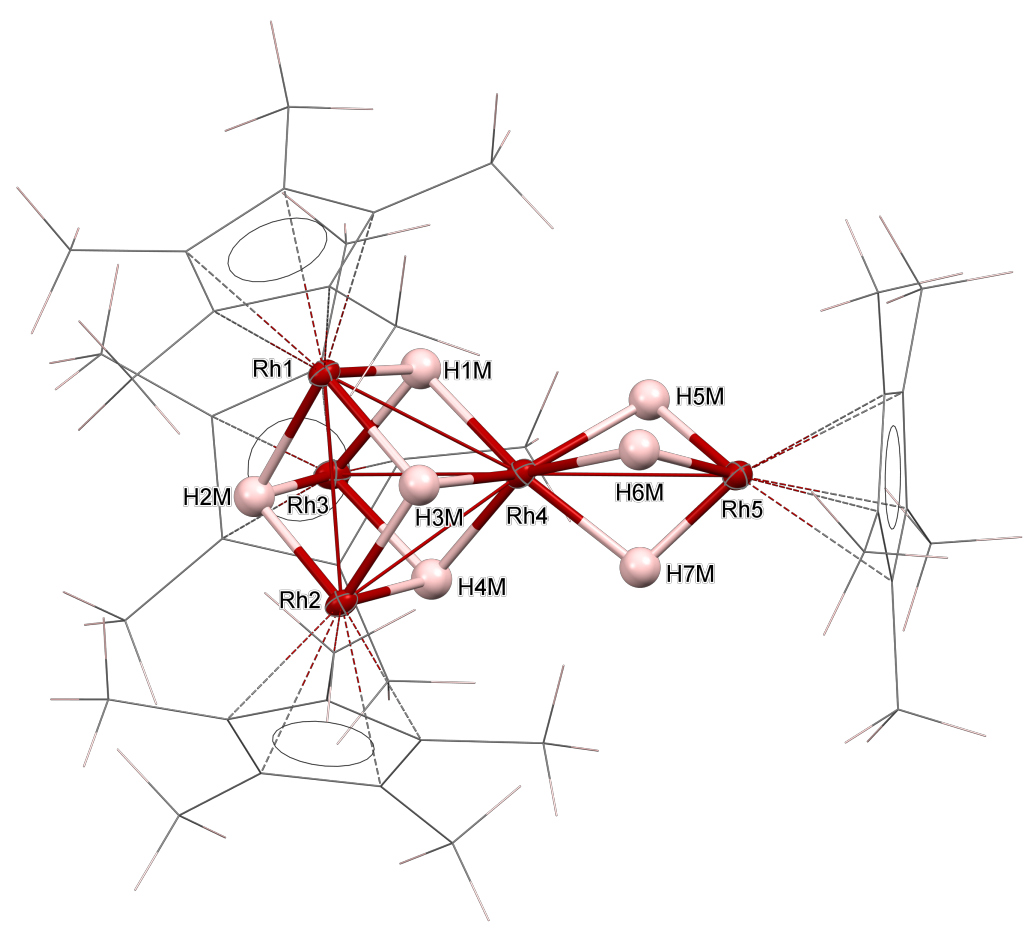

Figure S50. View of the molecule of $\left(\mathrm{C}_{5} \mathbf{M e}_{5}\right)_{4} \mathbf{R h}_{5} \mathbf{H}_{7}$ in $\left(\mathbf{C}_{5} \mathbf{M e}_{5}\right)_{4} \mathbf{R h}_{5} \mathbf{H}_{7} \cdot \mathbf{0 . 5 p e n t a n e}$ showing the atom labeling scheme for the $\mathrm{Rh}_{5} \mathrm{H}_{7}$ cluster (red ellipsoid $\mathrm{Rh}$, pink sphere Hydride, gray wireframe Carbon, pink wireframe hydrogen). The disordered pentane molecule in the crystal structure was omitted for clarity. 


\section{Crystal data}

Chemical formula

$M_{\mathrm{r}}$

Crystal system, space

group

Temperature (K)

$a(\AA ̊)$

$b(\AA ̊)$

$c(\AA ̊)$

$a\left(^{\circ}\right)$

$\beta\left(^{\circ}\right)$

$Y\left(^{\circ}\right)$

$V\left(\AA^{3}\right)$

$Z$

Radiation type

$\mu\left(\mathrm{mm}^{-1}\right)$

Crystal size $(\mathrm{mm})$

Data collection

Diffractometer

Absorption correction
$\mathrm{C}_{40} \mathrm{H}_{67} \mathrm{Rh}_{5} \cdot \mathrm{C}_{2.5} \mathrm{H}_{6}$

1098.55

Triclinic, $P-1$

100(2)

$11.8773(5)$

$13.7328(6)$

$15.6523(7)$

$92.034(2)$

$111.670(2)$

$111.675(2)$

$2160.73(17)$

2

Mo Ka

1.87

$0.17 \times 0.17 \times 0.13$

$0.95 \times 0.75 \times 0.15$

$\mathrm{C}_{40} \mathrm{H}_{67} \mathrm{Rh}_{5} \cdot \mathrm{C}_{2.5} \mathrm{H}_{6}$

1098.55

Triclinic, $P-1$

100(2)

$11.8563(15)$

$13.6978(15)$

$15.6364(19)$

$92.190(11)$

$111.587(10)$

$111.594(10)$

$2150.9(5)$

2

Neutrons, $\lambda=0.40-3.50 \AA$

$0.1632+0.1671 \lambda$

SNS TOPAZ

diffractometer

CMOS

diffractometer

Multi-scan

Sphere ${ }^{a}$ 

$T_{\min }, T_{\max }$
$0.694,0.746$
$0.729,0.909$
No. of measured,
$118002,13221,11716$
2797, 2007, 1994
independent and
observed $[/>2 \sigma(\Lambda)]$
reflections
$R_{\text {int }}$
0.029
0.106
Refinement
$R\left[F^{2}>2 \sigma\left(F^{2}\right)\right], w R\left(F^{2}\right), S \quad 0.027,0.057,1.13$
$0.118,0.238,1.10$
No. of reflections
13221
2007
No. of parameters
573
109
No. of restraints
0
1
$\mathrm{H}$-atom treatment
Only $\mathrm{H}$-atom displacement parameters refined
Only H-atom displacement parameters refined
$\Delta \rho_{\max }, \Delta \rho_{\min }$
$1.11,-0.93\left(\mathrm{e} \AA^{-3}\right)$
$0.78,-0.70\left(\mathrm{fm} \AA^{-3}\right)$

[a] C. W. Dwiggins, Jr., Acta Cryst. A 1975, 31, 395.

$\left(\mathrm{C}_{5} \mathrm{Me}_{5}\right)_{4} \mathrm{Rh}_{5} \mathrm{H}_{7}$ in $\left(\mathrm{C}_{5} \mathrm{Me}_{5}\right)_{4} \mathrm{Rh}_{5} \mathrm{H}_{7} \cdot 0.5$ pentane from single crystal neutron diffraction.

\begin{tabular}{llll}
\hline Rh1-H1M & $1.97(2)$ & Rh4-H1M & $1.88(3)$ \\
Rh1-H2M & $1.912(19)$ & Rh4-H3M & $1.827(17)$ \\
Rh1-H3M & $1.80(2)$ & Rh4-H4M & $1.83(2)$ \\
Rh2-H2M & $1.80(2)$ & Rh4-H5M & $1.91(3)$ \\
Rh2-H3M & $1.801(17)$ & Rh4-H6M & $1.93(4)$ \\
Rh2-H4M & $1.873(19)$ & Rh4-H7M & $1.78(4)$ \\
Rh3-H1M & $1.81(2)$ & Rh5-H5M & $1.71(4)$
\end{tabular}




$\begin{array}{llll}\text { Rh3-H2M } & 1.742(18) & \text { Rh5-H6M } & 1.62(4) \\ \text { Rh3-H4M } & 1.84(2) & \text { Rh5-H7M } & 1.60(3) \\ \text { Rh3-H1M-Rh4 } & 95.5(12) & \text { Rh1-H3M-Rh4 } & 96.8(8) \\ \text { Rh3-H1M-Rh1 } & 90.8(11) & \text { Rh4-H4M-Rh3 } & 95.7(10) \\ \text { Rh4-H1M-Rh1 } & 89.8(10) & \text { Rh4-H4M-Rh2 } & 92.7(8) \\ \text { Rh3-H2M-Rh2 } & 100.1(11) & \text { Rh3-H4M-Rh2 } & 94.0(11) \\ \text { Rh3-H2M-Rh1 } & 94.7(9) & \text { Rh5-H5M-Rh4 } & 89.3(15) \\ \text { Rh2-H2M-Rh1 } & 93.3(9) & \text { Rh5-H6M-Rh4 } & 91.1(16) \\ \text { Rh2-H3M-Rh1 } & 97.1(9) & \text { Rh5-H7M-Rh4 } & 97.6(17) \\ \text { Rh2-H3M-Rh4 } & 95.2(8) & & \end{array}$


Table S1. Crystal data and structure refinement for $\left(\eta^{5}-C_{5} M_{5}\right)_{4} \mathbf{R h}_{5} \mathbf{H}_{7} \cdot \mathbf{0 . 5 p e n t a n e}$.

Identification code

Empirical formula

Formula weight

Temperature

Wavelength

Crystal system

Space group

Unit cell dimensions

Volume

Z

Density (calculated)

Absorption coefficient

$\mathrm{F}(000)$

Crystal size

Theta range for data collection

Index ranges

Reflections collected

Independent reflections

Completeness to theta $=25.242^{\circ}$

Absorption correction

Max. and min. transmission

Refinement method

Data / restraints / parameters

Goodness-of-fit on $\mathrm{F}^{2}$

Final $\mathrm{R}$ indices [I $>2 \operatorname{sigma}(\mathrm{I})]$

$\mathrm{R}$ indices (all data)

Extinction coefficient

Largest diff. peak and hole n100k

C42.50 H73 Rh5

1098.55

100(2) K

$0.4-3.5 \AA$

Triclinic

P-1

$\mathrm{a}=11.8773(5) \AA$ $\alpha=92.034(2)^{\circ}$.

$\mathrm{b}=13.7328(6) \AA$ $\beta=111.670(2)^{\circ}$.

$\mathrm{c}=15.6523(7) \AA$ $\gamma=111.675(2)^{\circ}$.

2160.73(17) $\AA^{3}$

2

$1.688 \mathrm{Mg} / \mathrm{m}^{3}$

$(0.1632+0.1672 \lambda) \mathrm{mm}^{-1}$

1106

$0.950 \times 0.750 \times 0.150 \mathrm{~mm}^{3}$

2.739 to $25.745^{\circ}$.

$-10<=\mathrm{h}<=14,-16<=\mathrm{k}<=16,-17<=1<=18$

2797

$2007[\mathrm{R}(\mathrm{int})=0.1061]$

$25.4 \%$

Sphere

0.9085 and 0.7287

Full-matrix least-squares on $\mathrm{F}^{2}$

2007 / 1 / 109

1.102

$\mathrm{R} 1=0.1181, \mathrm{wR} 2=0.2376$

$\mathrm{R} 1=0.1184, \mathrm{wR} 2=0.2381$

$\mathrm{n} / \mathrm{a}$

0.775 and $-0.701\left(f m \AA^{-3}\right)$ 
Table S2. Selected bond lengths $[\AA]$ and angles $\left[{ }^{\circ}\right]$ for $\left(\boldsymbol{\eta}^{5}-\mathbf{C}_{5} \mathbf{M} \mathbf{e}_{5}\right)_{4} \mathbf{R h}_{5} \mathbf{H}_{7} \cdot \mathbf{0 . 5 p e n t a n e}$.

\begin{tabular}{|c|c|}
\hline $\mathrm{Rh}(1)-\mathrm{H}(1 \mathrm{M})$ & $1.97(2)$ \\
\hline $\mathrm{Rh}(1)-\mathrm{H}(2 \mathrm{M})$ & $1.917(19)$ \\
\hline $\mathrm{Rh}(1)-\mathrm{H}(3 \mathrm{M})$ & $1.81(2)$ \\
\hline $\mathrm{Rh}(2)-\mathrm{H}(2 \mathrm{M})$ & $1.81(2)$ \\
\hline $\mathrm{Rh}(2)-\mathrm{H}(3 \mathrm{M})$ & $1.805(17)$ \\
\hline $\mathrm{Rh}(2)-\mathrm{H}(4 \mathrm{M})$ & $1.875(19)$ \\
\hline $\mathrm{Rh}(3)-\mathrm{H}(1 \mathrm{M})$ & $1.81(2)$ \\
\hline $\mathrm{Rh}(3)-\mathrm{H}(2 \mathrm{M})$ & $1.743(18)$ \\
\hline $\mathrm{Rh}(3)-\mathrm{H}(4 \mathrm{M})$ & $1.85(2)$ \\
\hline $\mathrm{Rh}(4)-\mathrm{H}(1 \mathrm{M})$ & $1.88(3)$ \\
\hline $\mathrm{Rh}(4)-\mathrm{H}(3 \mathrm{M})$ & $1.828(17)$ \\
\hline $\mathrm{Rh}(4)-\mathrm{H}(4 \mathrm{M})$ & $1.83(2)$ \\
\hline $\mathrm{Rh}(4)-\mathrm{H}(5 \mathrm{M})$ & $1.91(3)$ \\
\hline $\mathrm{Rh}(4)-\mathrm{H}(6 \mathrm{M})$ & $1.93(4)$ \\
\hline $\mathrm{Rh}(4)-\mathrm{H}(7 \mathrm{M})$ & $1.78(4)$ \\
\hline $\mathrm{Rh}(5)-\mathrm{H}(5 \mathrm{M})$ & $1.71(4)$ \\
\hline $\mathrm{Rh}(5)-\mathrm{H}(6 \mathrm{M})$ & $1.62(4)$ \\
\hline $\mathrm{Rh}(5)-\mathrm{H}(7 \mathrm{M})$ & $1.61(3)$ \\
\hline $\mathrm{Rh}(3)-\mathrm{H}(1 \mathrm{M})-\mathrm{Rh}(4)$ & $95.4(12)$ \\
\hline $\mathrm{Rh}(3)-\mathrm{H}(1 \mathrm{M})-\mathrm{Rh}(1)$ & $91.0(11)$ \\
\hline $\mathrm{Rh}(4)-\mathrm{H}(1 \mathrm{M})-\mathrm{Rh}(1)$ & $89.9(10)$ \\
\hline $\mathrm{Rh}(3)-\mathrm{H}(2 \mathrm{M})-\mathrm{Rh}(2)$ & $100.0(11)$ \\
\hline $\mathrm{Rh}(3)-\mathrm{H}(2 \mathrm{M})-\mathrm{Rh}(1)$ & $94.8(9)$ \\
\hline $\mathrm{Rh}(2)-\mathrm{H}(2 \mathrm{M})-\mathrm{Rh}(1)$ & $93.3(9)$ \\
\hline $\mathrm{Rh}(2)-\mathrm{H}(3 \mathrm{M})-\mathrm{Rh}(1)$ & $97.2(9)$ \\
\hline $\mathrm{Rh}(2)-\mathrm{H}(3 \mathrm{M})-\mathrm{Rh}(4)$ & $95.1(8)$ \\
\hline $\mathrm{Rh}(1)-\mathrm{H}(3 \mathrm{M})-\mathrm{Rh}(4)$ & $96.8(8)$ \\
\hline $\mathrm{Rh}(4)-\mathrm{H}(4 \mathrm{M})-\mathrm{Rh}(3)$ & $95.7(10)$ \\
\hline $\mathrm{Rh}(4)-\mathrm{H}(4 \mathrm{M})-\mathrm{Rh}(2)$ & $92.6(8)$ \\
\hline $\mathrm{Rh}(3)-\mathrm{H}(4 \mathrm{M})-\mathrm{Rh}(2)$ & $93.9(11)$ \\
\hline $\mathrm{Rh}(5)-\mathrm{H}(5 \mathrm{M})-\mathrm{Rh}(4)$ & $89.3(15)$ \\
\hline $\mathrm{Rh}(5)-\mathrm{H}(6 \mathrm{M})-\mathrm{Rh}(4)$ & $91.0(16)$ \\
\hline $\mathrm{Rh}(5)-\mathrm{H}(7 \mathrm{M})-\mathrm{Rh}(4)$ & $97.4(17)$ \\
\hline
\end{tabular}


Symmetry transformations used to generate equivalent atoms:

Table S3. Hydrogen coordinates ( $\left.\times 10^{4}\right)$ and isotropic displacement parameters $\left(\AA^{2} \times 10^{3}\right)$ for $\left.\left(\eta^{5}-C_{5} M\right)_{5}\right)_{4} \mathbf{R h}_{5} \mathbf{H}_{7} \cdot 0.5 p e n t a n e$.

\begin{tabular}{|c|c|c|c|c|}
\hline & $\mathrm{x}$ & $\mathrm{y}$ & $\mathrm{z}$ & $\mathrm{U}(\mathrm{eq})$ \\
\hline $\mathrm{H}(1 \mathrm{M})$ & $4340(30)$ & $2740(20)$ & $7021(17)$ & $52(6)$ \\
\hline $\mathrm{H}(2 \mathrm{M})$ & $4670(20)$ & $1503(15)$ & $8173(13)$ & $31(4)$ \\
\hline $\mathrm{H}(3 \mathrm{M})$ & $6623(18)$ & $3079(14)$ & $8294(12)$ & $25(4)$ \\
\hline $\mathrm{H}(4 \mathrm{M})$ & $5430(20)$ & $1534(16)$ & $6943(14)$ & $35(5)$ \\
\hline $\mathrm{H}(5 \mathrm{M})$ & $5640(30)$ & $3650(30)$ & $5960(20)$ & $75(8)$ \\
\hline $\mathrm{H}(6 \mathrm{M})$ & $7510(40)$ & $4320(30)$ & $7250(30)$ & $87(10)$ \\
\hline $\mathrm{H}(7 \mathrm{M})$ & $7020(30)$ & $2970(30)$ & $6430(20)$ & $72(8)$ \\
\hline $\mathrm{H}(6 \mathrm{~A})$ & 8037 & 5209 & 9344 & $86(9)$ \\
\hline $\mathrm{H}(6 \mathrm{~B})$ & 8215 & 4734 & 10397 & $69(8)$ \\
\hline $\mathrm{H}(6 \mathrm{C})$ & 7941 & 5908 & 10264 & $35(4)$ \\
\hline $\mathrm{H}(7 \mathrm{~A})$ & 5608 & 2364 & 10594 & $60(7)$ \\
\hline $\mathrm{H}(7 \mathrm{~B})$ & 6000 & 3575 & 11295 & $108(13)$ \\
\hline $\mathrm{H}(7 \mathrm{C})$ & 7158 & 3447 & 10899 & $54(6)$ \\
\hline $\mathrm{H}(8 \mathrm{~A})$ & 3358 & 1781 & 9676 & $52(6)$ \\
\hline $\mathrm{H}(8 \mathrm{~B})$ & 2164 & 2078 & 8792 & $56(6)$ \\
\hline $\mathrm{H}(8 \mathrm{C})$ & 2843 & 2749 & 9965 & $65(7)$ \\
\hline $\mathrm{H}(9 \mathrm{~A})$ & 2772 & 4032 & 7241 & $110(13)$ \\
\hline $\mathrm{H}(9 \mathrm{~B})$ & 2430 & 4431 & 8167 & $79(9)$ \\
\hline $\mathrm{H}(9 \mathrm{C})$ & 1917 & 3061 & 7749 & $59(7)$ \\
\hline $\mathrm{H}(10 \mathrm{~A})$ & 4759 & 5281 & 7493 & $160(20)$ \\
\hline $\mathrm{H}(10 \mathrm{~B})$ & 6452 & 5513 & 8027 & $103(12)$ \\
\hline $\mathrm{H}(10 \mathrm{C})$ & 5833 & 6242 & 8539 & $61(7)$ \\
\hline $\mathrm{H}(16 \mathrm{~A})$ & 8915 & 2403 & 7501 & $99(11)$ \\
\hline $\mathrm{H}(16 \mathrm{~B})$ & 10223 & 2545 & 8578 & $71(8)$ \\
\hline $\mathrm{H}(16 \mathrm{C})$ & 9389 & 3394 & 8466 & $106(12)$ \\
\hline $\mathrm{H}(17 \mathrm{~A})$ & 8531 & 3002 & 10598 & $82(9)$ \\
\hline $\mathrm{H}(17 \mathrm{~B})$ & 9354 & 3611 & 9897 & $92(10)$ \\
\hline
\end{tabular}




\begin{tabular}{|c|c|c|c|c|}
\hline $\mathrm{H}(17 \mathrm{C})$ & 9944 & 2816 & 10646 & $84(9)$ \\
\hline $\mathrm{H}(18 \mathrm{~A})$ & 5899 & 76 & 10020 & $126(9)$ \\
\hline $\mathrm{H}(18 \mathrm{~B})$ & 6797 & 1441 & 10559 & $126(9)$ \\
\hline $\mathrm{H}(18 \mathrm{C})$ & 7606 & 569 & 10765 & $126(9)$ \\
\hline $\mathrm{H}(19 \mathrm{~A})$ & 4852 & -893 & 8491 & $87(6)$ \\
\hline $\mathrm{H}(19 \mathrm{~B})$ & 6134 & -1342 & 8769 & $87(6)$ \\
\hline $\mathrm{H}(19 \mathrm{C})$ & 5326 & -1207 & 7611 & $87(6)$ \\
\hline $\mathrm{H}(20 \mathrm{~A})$ & 7042 & 811 & 6618 & $97(11)$ \\
\hline $\mathrm{H}(20 \mathrm{~B})$ & 6403 & -480 & 6850 & $118(14)$ \\
\hline $\mathrm{H}(20 \mathrm{C})$ & 8127 & 213 & 7183 & $49(6)$ \\
\hline $\mathrm{H}(26 \mathrm{~A})$ & 4221 & -55 & 5287 & $66(7)$ \\
\hline $\mathrm{H}(26 \mathrm{~B})$ & 2754 & -1244 & 4845 & $45(5)$ \\
\hline $\mathrm{H}(26 \mathrm{C})$ & 3950 & -1004 & 6000 & $64(7)$ \\
\hline $\mathrm{H}(27 \mathrm{~A})$ & 2390 & -1071 & 7704 & $63(7)$ \\
\hline $\mathrm{H}(27 \mathrm{~B})$ & 3080 & -1493 & 7020 & $45(5)$ \\
\hline $\mathrm{H}(27 \mathrm{C})$ & 1339 & -1966 & 6618 & $34(5)$ \\
\hline $\mathrm{H}(28 \mathrm{~A})$ & 1536 & 215 & 7904 & $60(7)$ \\
\hline $\mathrm{H}(28 \mathrm{~B})$ & 20 & -481 & 6917 & $99(11)$ \\
\hline $\mathrm{H}(28 \mathrm{C})$ & 689 & 926 & 7222 & $83(9)$ \\
\hline $\mathrm{H}(29 \mathrm{~A})$ & 1729 & 2462 & 5545 & $68(7)$ \\
\hline $\mathrm{H}(29 \mathrm{~B})$ & 903 & 1989 & 6278 & $74(8)$ \\
\hline $\mathrm{H}(29 \mathrm{C})$ & 161 & 1367 & 5085 & $170(30)$ \\
\hline $\mathrm{H}(30 \mathrm{~A})$ & 3736 & 1268 & 4740 & $109(13)$ \\
\hline $\mathrm{H}(30 \mathrm{~B})$ & 3006 & 2142 & 4866 & $64(7)$ \\
\hline $\mathrm{H}(30 \mathrm{C})$ & 2035 & 917 & 4053 & $47(6)$ \\
\hline $\mathrm{H}(36 \mathrm{~A})$ & 5769 & 3349 & 3744 & $63(7)$ \\
\hline $\mathrm{H}(36 \mathrm{~B})$ & 7013 & 2862 & 3979 & $65(7)$ \\
\hline $\mathrm{H}(36 \mathrm{C})$ & 7090 & 3953 & 3407 & $93(11)$ \\
\hline $\mathrm{H}(37 \mathrm{~A})$ & 8763 & 2865 & 5165 & $66(7)$ \\
\hline $\mathrm{H}(37 \mathrm{~B})$ & 10016 & 3579 & 6282 & $84(9)$ \\
\hline $\mathrm{H}(37 \mathrm{C})$ & 10183 & 3984 & 5262 & $58(6)$ \\
\hline $\mathrm{H}(38 \mathrm{~A})$ & 10360 & 5973 & 7772 & $41(5)$ \\
\hline $\mathrm{H}(38 \mathrm{~B})$ & 11322 & 6205 & 7110 & $63(7)$ \\
\hline $\mathrm{H}(38 \mathrm{C})$ & 10733 & 4944 & 7408 & $86(9)$ \\
\hline $\mathrm{H}(39 \mathrm{~A})$ & 8960 & 6766 & 7337 & $27(4)$ \\
\hline H(39B) & 7544 & 6763 & 6416 & $43(5)$ \\
\hline
\end{tabular}




\begin{tabular}{lrrrr}
$\mathrm{H}(39 \mathrm{C})$ & 9135 & 7454 & 6432 & $77(8)$ \\
$\mathrm{H}(40 \mathrm{~A})$ & 5380 & 4781 & 4143 & $51(6)$ \\
$\mathrm{H}(40 \mathrm{~B})$ & 6565 & 5995 & 4098 & $53(6)$ \\
$\mathrm{H}(40 \mathrm{C})$ & 6021 & 5930 & 5010 & $48(5)$ \\
$\mathrm{H}(1 \mathrm{~S} 1)$ & 10156 & 801 & 9515 & $67(4)$ \\
$\mathrm{H}(1 \mathrm{~S} 2)$ & 11328 & 239 & 10050 & $67(4)$ \\
$\mathrm{H}(2 \mathrm{~S} 1)$ & 8346 & -838 & 9548 & $67(4)$ \\
$\mathrm{H}(2 \mathrm{~S} 2)$ & 9530 & -1399 & 10045 & $67(4)$ \\
$\mathrm{H}(3 \mathrm{~S} 1)$ & 8882 & -756 & 8140 & $84(6)$ \\
$\mathrm{H}(3 \mathrm{~S} 2)$ & 8208 & -2065 & 8330 & $84(6)$ \\
$\mathrm{H}(3 \mathrm{~S} 3)$ & 9928 & -1412 & 8626 & $84(6)$ \\
$\mathrm{H}(4 \mathrm{~S} 1)$ & 9620 & 781 & 10892 & $67(4)$ \\
$\mathrm{H}(4 \mathrm{~S} 2)$ & 10670 & 115 & 11420 & $67(4)$ \\
$\mathrm{H}(5 \mathrm{~S} 1)$ & 12609 & 1700 & 11495 & $84(6)$ \\
$\mathrm{H}(5 \mathrm{~S} 2)$ & 11774 & 2004 & 12121 & $84(6)$ \\
$\mathrm{H}(5 \mathrm{~S} 3)$ & 11560 & 2355 & 11017 & $84(6)$ \\
\hline
\end{tabular}




\section{References}

1. Pangborn, A. B.; Giardello, M. A.; Grubbs, R. H.; Rosen, R. K.; Timmers, F. J. Safe and Convenient Procedure for Solvent Purification. Organometallics 1996, 15, 1518-1520.

2. Hu, Y.; Shaw, A. P.; Norton, J. R.; Sattler, W.; Rong, Y. Synthesis, Electrochemistry, and Reactivity of New Iridium(III) and Rhodium(III) Hydrides. Organometallics 2012, 31, 5058-5064.

3. Dai, X.-J.; Li, C.-J. En Route to a Practical Primary Alcohol Deoxygenation. J. Am. Chem. Soc. 2016, 138, 5433-5440.

4. Patel, A. V.; Blunden, G.; Crabb, T. A. NMR spectra and stereochemistry of N-acetyl and N-benzoyl derivatives of solasodine. Magn. Reson. Chem. 1991, 29, 794-800.

5. (a) For cis-isomer: Ribeiro da Silva, M. A. V.; Cabral, J. I. T. A.; Gomes, P.; Gomes, J. R. B. Combined Experimental and Computational Study of the Thermochemistry of Methylpiperidines. J. Org. Chem. 2006, 71, 3677-3685. (b) For trans-isomer: Fréville, S.; Bonin, M.; Célérier, J.-P.; Husson, H.-P.; Lhommet, G.; Quirion, J.-C.; Thuy, V. M. Asymmetric Synthesis of (+) and (-) trans-2,6-dimethylpiperidines. Tetrahedron 1997, 53, 8447-8456.

6. STUDIENGESELLSCHAFT KOHLE MBH; Glorius, F. Method for Synthesising Optically Active Piperidines by the Hydrogenation of Optically Active Pyridines. (2005), WO2005049570, A1.

7. van Duzer, J. H.; Michaelis, A. F.; Geiss, W. B.; Stafford, D. G.; Raker, J. (2005) U.S. Patent No. US2005043298.

8. Zhang, Y.; César, V.; Storch, G.; Lugan, N.; Lavigne, G. Skeleton Decoration of NHCs by Amino Groups and its Sequential Booster Effect on the Palladium-Catalyzed Buchwald-Hartwig Amination. Angew. Chem. Int. Ed. 2014, 53, 6482-6486.

9. Fulmer, G. R.; Miller, A. J. M.; Sherden, N. H.; Gottlieb, H. E.; Nudelman, A.; Stoltz, B. M.; Bercaw, J. E.; Goldberg, K. I. NMR Chemical Shifts of Trace Impurities: Common Laboratory Solvents, Organics, and Gases in Deuterated Solvents Relevant to the Organometallic Chemist. Organometallics 2010, 29, 2176-2179.

10. Meuresch, M.; Westhues, S.; Leitner, W.; Klankermayer, J. Tailer-Made RutheniumTriphos Catalysts for the Selective Homogeneous Hydrogenation of Lactams. Angew. Chem. Int. Ed. 2016, 55, 1392-1395.

11. Aoyagi, N.; Furusho, Y.; Sei, Y.; Endo, T. Fast equilibrium of zwitterionic adduct formation in reversible fixation-release system of $\mathrm{CO} 2$ by amidines under dry conditions. Tetrahedron 2013, 69, 5476-5480.

12. Dervan, P. B.; Santilli, D. S. Synthesis and thermal decomposition of cis-3,4,5,6tetrahydropyridazine-3,4-d2. Relative rates of rotation, cleavage, and closure for tetramethylene. J. Am. Chem. Soc. 1980, 102, 3863-3870. 
13. Li, Z.; Liu, L.; Sun, H.-m.; Shen, Q.; Zhang, Y. Alkyl Grignard cross-coupling of aryl phosphates catalyzed by new, highly active ionic iron(II) complexes containing a phosphine ligand and an imidazolium cation. Dalton Trans. 2016, 45, 17739-17747.

14. Mahato, S.; Jana, C. K. Iterative direct $\mathrm{C}(\mathrm{sp} 3)-\mathrm{H}$ functionalization of amines: diastereoselective divergent synthesis of $\alpha, \alpha^{\prime}$-disubstituted alicyclic amines. Org. Biomol. Chem. 2017, 15, 1655-1660.

15. Williams, G. D.; Pike, R. A.; Wade, C. E.; Willis, M. A One-Pot Process for the Enantioselective Synthesis of Amines via Reductive Amination under Transfer Hydrogenation Conditions. Org. Lett. 2003, 5, 4227-4230.

16. Bokorny, S.; Connor, J. A.; Kaspar, H. Complexes of polyhydro-2,2'-bipyridines with molybdenum and tungsten carbonyls.

17. Denmark, S. E.; Fu, J.; Lawler, M. J. Chiral Phosphoramide-Catalyzed Enantioselective Addition of Allylic Trichlorosilanes to Aldehydes. Preparative Studies with Bidentate Phosphorus-Based Amides. J. Org. Chem. 2006, 71, 1523-1536.

18. Shibagaki, M.; Matsushita, H.; Kaneko, H. The Synthesis of 2'S,3R- and 2'S,3SHexahydronicotine. Heterocycles 1985, 23, 2351-2356.

19. Xi, L-Y.; Zhang, R.-Y.; Liang, S.; Chen, S.-Y.; Yu, X.-Q. Copper-Catalyzed Aerobic Synthesis of 2-Arylpyridines from Acetophenones and 1,3-Diaminopropane. Org. Lett. 2014, 16, 5269-5271.

20. Nador, F.; Moglie, Y.; Vitale, C.; Yus, M.; Alonso, F.; Radivoy, G. Reduction of polycylic aromatic hydrocarbons promted by cobalt or manganese nanoparticles. Tetrahedron 2010, 66, 4318-4325.

21. Adam, R.; Cabrero-Antonino, J. R.; Spannenberg, A.; Junge, K.; Jackstell, R.; Beller, M. A General and Highly Selective Cobalt-Catalyzed Hydrogenation of N-Heteroarenes under Mild Reaction Conditions. Angew. Chem. Int. Ed. 2017, 56, 3216-3220.

22. Martinez, R.; Ramón, D. J.; Yus, M. Transition-Metal-Free Indirect Friedländer Synthesis of Quinolines from Alcohols. J. Org. Chem. 2008, 73, 9778-9780.

23. Borowski, A. F.; Vendier, L.; Sabo-Etienne, S.; Rozycka-Sokolowska, E.; Gaudyn, A. V. Catalyzed hydrogenation of condensed three-ring arenes and their N-heteroaromatic analogues by a bis(dihydrogen) ruthenium complex. Dalton Trans. 2012, 41, 1411714125.

24. Ganji, P.; van Leeuwen, P. W. N. M. Phosphine Supported Ruthenium Nanoparticle Catalyzed Synthesis of Substituted Pyrazines and Imidazoles from a-Diketones. J. Org. Chem. 2017, 82, 1768-1774.

25. Chun, S.; Chung, Y. K. Transition-Metal-Free Poly(thiazolium) lodide/1,8Diazabicyclo[5.4.0]undec-7-ene/Phenazine-Catalyzed Esterification of Aldehydes with Alcohols. Org. Lett. 2017, 19, 3787-3790. (cross checked in DMSO-d ${ }_{8}$ ) 
26. Gruber, C. C.; Oberdorfer, G.; Voss, C. V.; Kremsner, J. M.; Kappe, C. O.; Kroutil, W. An Algorithm for the Deconvolution of Mass Spectroscopic Patters in Isotope Labeling Studies. Evaluation for the Hydrogen-Deuterium Exchange Reaction in Ketones. J. Org. Chem. 2007, 72, 5778-5783.

27. Coates, L.; Cao, H. B.; Chakoumakos, B. C.; Frontzek, M. D.; Hoffmann, C.; Kovalevsky, A. Y.; Liu, Y.; Meilleur, F.; dos Santos, A. M.; Myles, D. A. A.; Wang, X. P.; Ye, F., A suite-level review of the neutron single-crystal diffraction instruments at Oak Ridge National Laboratory. Rev. Sci. Instrum. 2018, 89, 092802.

28. Zikovsky, J.; Peterson, P. F.; Wang, X. P. P.; Frost, M.; Hoffmann, C., CrystalPlan: an experiment-planning tool for crystallography. J. Applied Crystallogr. 2011, 44, 418-423.

29. Schultz, A. J.; Jørgensen, M. R. V.; Wang, X.; Mikkelson, R. L.; Mikkelson, D. J.; Lynch, V. E.; Peterson, P. F.; Green, M. L.; Hoffmann, C. M., Integration of neutron time-of-flight single-crystal Bragg peaks in reciprocal space. J. Appl. Cryst. 2014, 47, 915-921.

30. Schultz, A. J.; Srinivasan, K.; Teller, R. G.; Williams, J. M.; Lukehart, C. M., Single-crystal time-of-flight neutron-diffraction structure of hydrogen cis-diacetyltetracarbonylrhenate, cis- $(\mathrm{OC})_{4} \mathrm{Re}\left(\mathrm{CH}_{3} \mathrm{CO}\right)_{2} \mathrm{H}$ - a metallaacetylacetone molecule. J. Am. Chem. Soc. 1984, 106, 999-1003.

31. Sheldrick, G. M., Crystal structure refinement with SHELXL. Acta Cryst. C-Structural Chemistry 2015, 71, 3-8.

32. Hübschle, C. B., Sheldrick, G. M., Dittricha, B. ShelXle: a Qt graphical user interface for SHELXL. J. Appl. Cryst. 2011 44, 1281-1284.

33. Farrugia, L. J., WinGX and ORTEP for Windows: an update. J. Appl. Cryst. 2012, 45, 849854. 